\title{
EFEITO DE UMA GERAÇÃO ADICIONAL DE RECOMBINAÇÃO SOBRE A RESPOSTA À SELEÇÃO RECORRENTE EM MILHO
}

(Zea mays L.)

\author{
FRANCISCO PINHEIRO LIMA NETO \\ Engenheiro Agrônomo
}

Orientador: Prof. Dr. CLÁUDIO LOPES DE SOUZA JÚNIOR

\begin{abstract}
Tese apresentada à Escola Superior de Agricultura "Luiz de Queiroz", da Universidade de São Paulo, para obtenção do título de Doutor em Agronomia, Área de Concentração: Genética e Melhoramento de Plantas
\end{abstract}

\author{
P I R A C I C A B A \\ Estado de São Paulo - Brasil \\ Julho - 1998
}


Dados Internacionais de Catalogação na Publicação (CIP)

DIVISÃO DE BIBLIOTECA E DOCUMENTAÇÃO - Campus "Luiz de Queiroz"/USP

Lima Neto, Francisco Pinheiro

Efeito de uma geração adicional de recombinação sobre a resposta à seleção recorrente em milho (Zea mays L.) / Francisco Pinheiro Lima Neto. - - Piracicaba, 1998.

$150 \mathrm{p}$.

Tese (doutorado) - - Escola Superior de Agricultura Luiz de Queiroz, 1998. Bibliografia.

1. Melhoramento genético vegetal 2. Milho 3. Recombinação genética 4. Seleção genética vegetal 5 . Seleção recorrente 6 . Variabilidade genética I. Titulo

CDD 633.15 
Dedico a

Meu pai, Francisco Pinheiro Lima Júnior,

Minha mãe, Lice Maria Machado Pinheiro Lima,

Minha irmã, Francesca,

Às memórias

de minha tia, Maria de Lourdes Lima,

e do amigo, Ivan Pereira de Freitas Filho 


\section{AGRADECIMENTOS}

Ao Prof. Dr. Cláudio Lopes de Souza Júnior, pela orientação e pelos conhecimentos adquiridos.

Ao Prof. Dr. Isaías Olívio Geraldi, pelo decisivo apoio e pelas valiosas sugestões.

Aos amigos Daniel Furtado Ferreira, Antônio Augusto Franco Garcia, Eduardo Bearzoti, Rogério de Melo Costa Pinto, Rhainer Gleico Cardoso, Galo Mário Caviedes Cepeda, Júlio Sílvio de Sousa Bueno Filho e Sebastião Soares Simeão Filho e, especialmente, à amiga Elaine Aparecida de Souza, pelo inestimável auxilio nas análises estatísticas.

À técnica Elisabete Aparecida Leone Rodrigues, pelo auxílio na manipulação do SAS.

Aos funcionários Antônio Jocelino Desidério, Alfredo Araújo e Ariberto Soares de Oliveira, pela condução dos ensaios experimentais e pelo auxílio na coleta dos dados.

À bibliotecária Silvana Marchizelli Gregório, pela revisão das normas bibliográficas.

A meu pai e a minha mãe pela revisão ortográfica e gramatical. 


\section{SUMÁRIO}

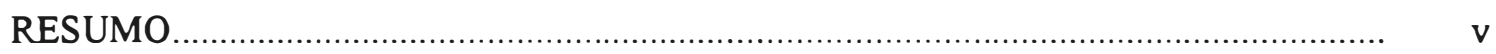

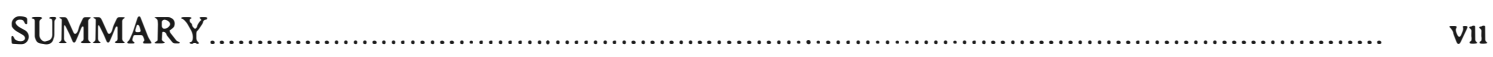

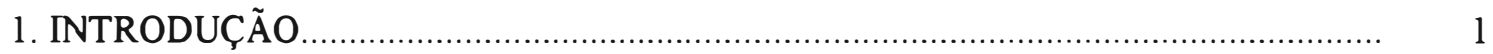

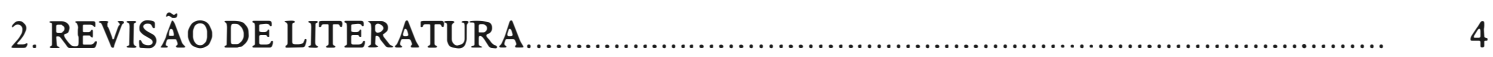

2.1. Seleção recorrente intra e interpopulacional em milho ........................................... 4

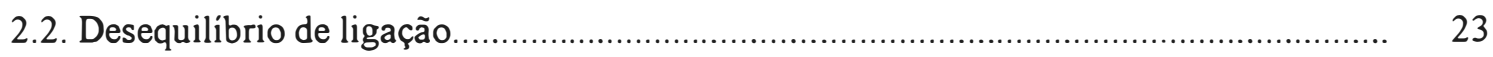

2.3. Desequilíbrio de ligação e melhoramento................................................................. 28

2.3.1. Efeitos do desequilíbrio nas estimativas de variâncias genéticas............................ 28

2.3.2. Efeitos do desequilibrio no melhoramento..................................................... 34

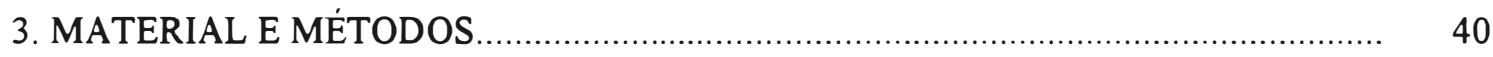

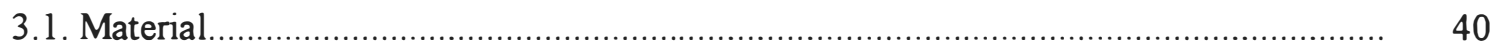

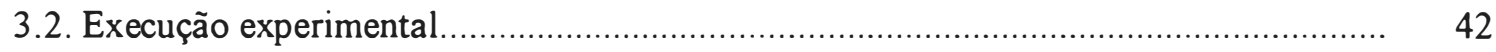

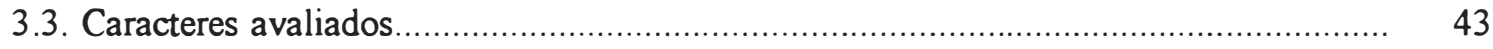

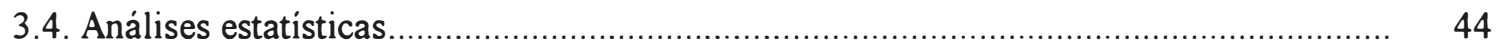

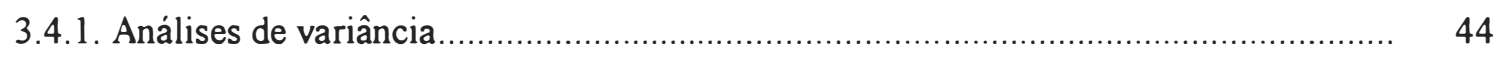

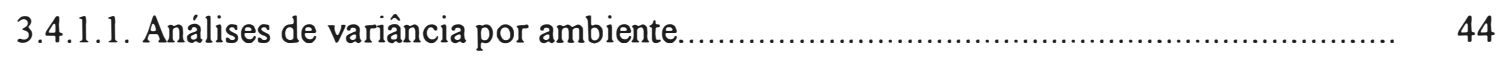

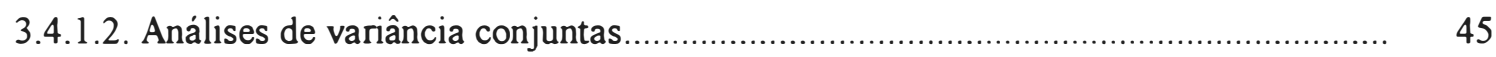

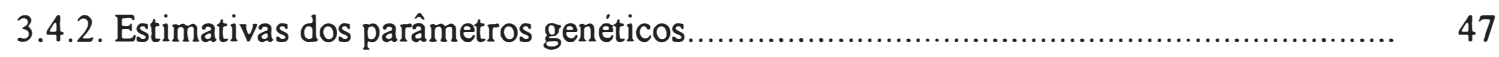

3.4.3. Intervalos de confiança associados aos parâmetros genéticos ............................... 50

3.4.4. Testes de comparações de variâncias e de médias................................................... 53

3.4.5. Análises de covariância e cálculo das estimativas dos coeficientes de correlação..... 55

3.4.6. Intervalos de confiança associados às correlações e testes de significância............... 57

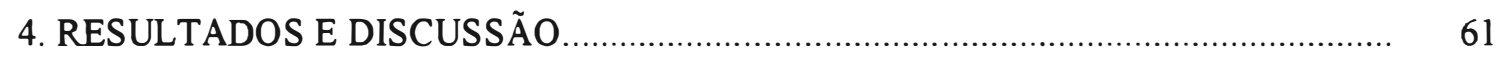

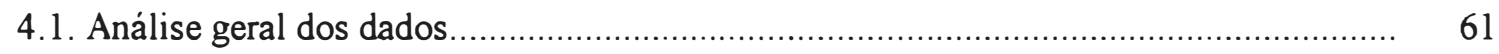

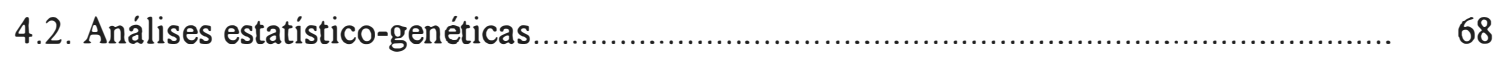

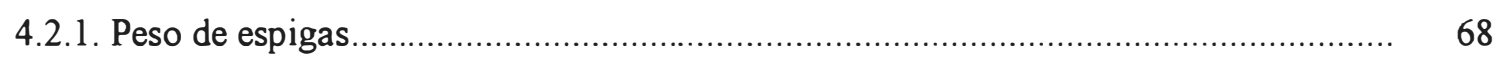

4.2.2. Altura da planta, altura da espiga e posição relativa da espiga ............................... 72

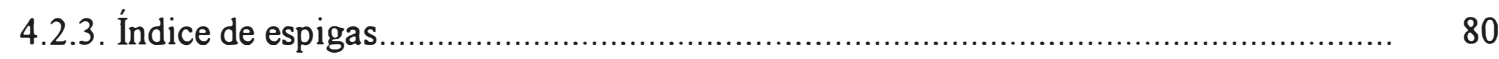

4.3. Correlações genéticas e fenotípicas ........................................................................ 83

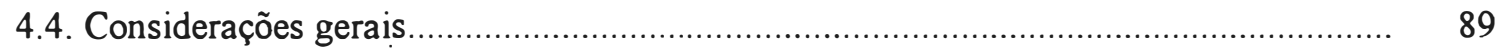

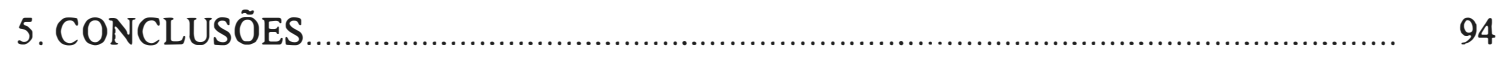

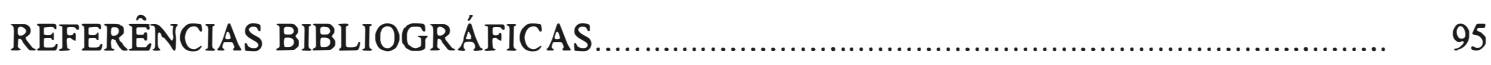

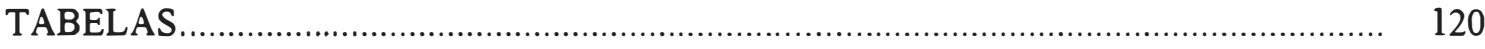




\title{
EFEITO DE UMA GERAÇÃO ADICIONAL DE RECOMBINAÇÃO SOBRE A RESPOSTA À SELEÇÃO RECORRENTE EM MLHO (Zea mays L.)
}

\author{
Autor: FRANCISCO PINHEIRO LIMA NETO \\ Orientador: Prof. Dr. CLÁUDIO LOPES DE SOUZA JÚNIOR
}

\section{RESUMO}

A seleção recorrente é um procedimento cíclico do melhoramento destinado a elevar gradualmente a frequência dos alelos favoráveis dos caracteres sob seleção e, simultaneamente, a manter a variabilidade genética para ciclos posteriores. Assim, as populações sob o processo de seleção recorrente são gradativamente melhoradas com os sucessivos ciclos. Cada ciclo da seleção recorrente inclui quatro fases distintas: (1) obtenção de progênies, (2) avaliação das progênies em experimentos com repetições, (3) seleção das progênies superiores e (4) recombinação das progênies selecionadas.

A última fase compreende intercruzamentos entre as progênies selecionadas visando gerar variabilidade genética para o próximo ciclo seletivo. Realiza-se, em geral, apenas uma geração de recombinação. Entretanto, o processo seletivo desencadeia o desequilíbrio de ligação, o qual não é dissipado com apenas uma única geração de recombinação. Assim, uma única geração de recombinação entre os genótipos selecionados não é suficiente para que as populações sob seleção atinjam o equilíbrio de ligação. O desequilíbrio de ligação diminui a variabilidade genética e, portanto, pode comprometer a resposta à seleção nos ciclos seguintes.

O presente trabalho foi conduzido com o objetivo de avaliar se uma geração adicional de recombinação liberaria mais variabilidade genética do que uma única geração, além de verificar se a resposta esperada à seleção após duas gerações de recombinação seria de magnitude tal que compensasse a realização do ciclo adicional. 
O material utilizado foi derivado de vinte progênies selecionadas da população de milho ESALQ-PB 4, a qual estava sob seleção recorrente recíproca com progênies de meios irmãos com a população ESALQ-PB 5. Vinte progênies $S_{1}$ foram recombinadas uma vez, de acordo com a metodologia usualmente empregada, e a população originada foi submetida a um novo ciclo de recombinação. De cada geração de recombinação cem progênies de meios irmãos e cem progênies de irmãos germanos foram obtidas, totalizando assim quatrocentas progênies, as quais foram avaliadas em látices $10 \times 10$ em três ambientes e com duas repetições por ambiente.

Os caracteres analisados foram o peso de espigas, a altura da planta, a altura da espiga, a posição relativa da espiga e o número de espigas por planta. Estimativas das médias, das variâncias genéticas e fenotípicas, dos coeficientes de herdabilidade e das correlações genéticas entre os caracteres analisados foram obtidas para cada tipo de progênie em cada geração de recombinação.

Os resultados sugeriram que não houve nenhuma diferença significativa na magnitude dos parâmetros mencionados com uma geração adicional de recombinação para os dois tipos de progênie considerados em nenhum dos caracteres avaliados. Assim, conclui-se que uma geração adicional de recombinação não proporcionou nenhum beneficio que pudesse justificar o emprego da metodologia proposta em programas de seleção recorrente. 


\title{
EFFECTS OF AN ADDITIONAL GENERATION OF RECOMBINATION ON THE RESPONSE TO RECURRENT SELECTION IN MAIZE (Zea mays L.)
}

\author{
Author: FRANCISCO PINHEIRO LIMA NETO \\ Adviser: Prof. Dr. CLÁUDIO LOPES DE SOUZA JÚNIOR
}

\section{SUMMARY}

Recurrent selection is a cyclical breeding procedure outlined to gradually increase the frequency of favorable alleles of the traits under selection and, simultaneously, maintaining genetic variability for continued selection. Then, the populations under recurrent selection are gradually improved with the succeeding cycles of selection. Each cycle of recurrent selection include four distinct phases: (1) production of progenies, (2) evaluation of progenies in replicated experiments, (3) selection of superior progenies and (4) recombination of selected progenies.

The last phase is conducted by intermating the selected progenies to generate genetic variability for the next selection cycle and, usually, only one generation of recombination is made. However, selection causes linkage disequilibrium and it is well known that one generation of recombination is not enough to bring the populations under selection to a linkage equilibrium state. Linkage disequilibrium diminishes genetic variability and, thus, the response to selection for the character could also be diminished.

This research was carried out to evaluate whether an additional generation of recombination could release more genetic variability than only one generation of recombination and whether the response to selection under two generations of recombination would be greater enough to compensate this extra generation. 
The material used was derived from twenty selected progenies of ESALQ-PB 4 maize population that was under half-sib reciprocal recurrent selection with ESALQPB 5 maize population. Twenty $S_{1}$ progenies were recombined one time, as usually is made, and two times. From each generation of recombination one hundred half-sib and one hundred full-sib progenies were obtained, totaling four hundred progenies, which were evaluated in $10 \times 10$ lattice designs in three environments with two replications per environment.

Data were recorded for ears weight, plant height, ear height, ear placement and number of ears per plant. Estimates of means, genetic and phenotypic variances, heritability coefficients and genetic correlations between traits were obtained for each type of progeny in each generation of recombination.

The results showed that there were no significant differences in those genetic parameters with one or two generations of recombination for the two types of progeny considered and for all traits recorded. Thus, one additional generation of recombination did not bring any benefit that could justify its utilization in recurrent selection programs. 


\section{INTRODUÇÃO}

Seleção recorrente é uma expressão que foi introduzida por Hull (1945) e designa qualquer processo de seleção que é repetido continuamente. A seleção recorrente é um método de melhoramento que visa aumentar, contínua e progressivamente, a frequência dos alelos favoráveis nas populações, evitando, contudo, esgotar a variabilidade genética, a qual continuará a ser aproveitada nos próximos ciclos seletivos. Com exceção da seleção massal, a seleção recorrente é um processo formado por quatro etapas distintas: obtenção de progênies, avaliação das progênies em experimentos com repetições, seleção das progênies superiores baseando-se nas médias dos experimentos e recombinação das progênies selecionadas visando gerar variabilidade genética para ser aproveitada nos ciclos posteriores. A seleção recorrente promove, portanto, o melhoramento genético das populações, as quais poderão ser utilizadas, pelos agricultores, como variedades, ou, pelas empresas de pesquisa, como fontes de linhagens endogâmicas para a produção de hibridos (Souza Júnior, 1989).

A elevação da frequência dos alelos favoráveis nas populações de plantas pode ser obtida através de diferentes estratégias empregadas na seleção recorrente, as quais variam principalmente em relação ao número de populações incluídas no processo seletivo, aos diferentes tipos de progênie usados como unidades de seleção e de recombinação, aos tamanhos efetivos populacionais e aos caracteres sob seleção. As estimativas das respostas esperadas com a seleção são proporcionadas pelos múltiplos e sucessivos ciclos seletivos das diversas estratégias da seleção recorrente. Tais estimativas possibilitam, portanto, a mensuração da eficiência relativa das diversas metodologias utilizadas na seleção recorrente (Rodriguez \& Hallauer, 1988). 
As unidades de seleção e de recombinação podem ser constituídas por progênies do mesmo tipo ou por progênies de tipos diferentes, as quais podem ser combinadas, como comumente acontece nos programas de seleção recorrente. A descrição de cada metodologia permite a obtenção das respectivas expressões das respostas esperadas com a seleção, possibilitando, portanto, o discernimento da estratégia mais eficiente (Souza Júnior, 1989).

O propósito primário da seleção recorrente, em programas de melhoramento genético do milho, é promover o melhoramento das populações, as quais podem ser usadas como fontes de linhagens endogâmicas para a produção de híbridos. Se o procedimento for eficaz para os caracteres sob seleção, a probabilidade de selecionar linhagens endogâmicas superiores será maior na população melhorada do que na população original, o que certamente acarretará melhor desempenho dos híbridos sintetizados (Russell, 1985).

A seleção recorrente pode ser aplicada tanto ao melhoramento genético intrapopulacional como também ao melhoramento genético interpopulacional. No melhoramento intrapopulacional, a seleção recorrente visa o melhoramento das populações, individualmente, enquanto que, no melhoramento interpopulacional, a seleção recorrente objetiva o melhoramento do híbrido sintetizado a partir de duas populações envolvidas no processo.

Vários pesquisadores relataram, assim, resultados dos efeitos da seleção recorrente, a qual promove alterações nas médias e também nas variâncias genéticas dos caracteres analisados em populações de milho submetidas ao processo de melhoramento (Moll \& Smith, 1981; Smith, 1983; Tanner \& Smith, 1987; Helms et al., 1989a; Helms et al., 1989b; Eyherabide \& Hallauer, 199la; Eyherabide \& Hallauer, 1991b; Keeratinijakal \& Lamkey, 1993a; Keeratinijakal \& Lamkey, 1993b; Pandey et al., 1994).

Na seleção recorrente, a recombinação das progênies selecionadas visa gerar variabilidade genética para poder ser aproveitada nos ciclos seletivos seguintes. Contudo, a recombinação é geralmente efetuada apenas uma única vez por ciclo, a fim de evitar, assim, o alongamento do processo seletivo no programa de melhoramento. 
Não há relatos, portanto, na literatura, de trabalhos que tenham sido conduzidos com o propósito de mensurar a alteração na variabilidade genética e na resposta esperada à seleção recorrente propiciada por um ciclo de recombinação adicional àquele normalmente efetuado. Para o melhoramento, ciclos adicionais de recombinação proporcionados pela seleção recorrente pretendem gerar variabilidade genética adicional para ser aproveitada nos ciclos seletivos posteriores, graças aos novos arranjos gênicos que poderão vir a ser formados.

Teoricamente, espera-se que somente uma geração de recombinação não seja suficiente nem para estabelecer o equilíbrio na população sob observação nem para propiciar o aparecimento de diversas combinações gênicas desejáveis no processo de melhoramento genético, pois os blocos de ligação existentes entre os genes não são instantaneamente quebrados, mas apenas gradativamente. As ligações gênicas desencadeiam um tipo de desequilíbrio nas populações, o desequilíbrio de ligação, que é determinado tanto pela seleção como pela redução do tamanho efetivo populacional (Falconer, 1989).

O objetivo do presente trabalho foi quantificar os efeitos de um ciclo adicional de recombinação em progênies selecionadas de um programa de melhoramento genético, com o intuito de avaliar se o procedimento proposto seria recomendável ou não para aumentar a eficácia do método da seleção recorrente. 


\section{REVISÃO DE LITERATURA}

\subsection{SELEÇÃO RECORRENTE INTRA E INTERPOPULACIONAL EM MLHO}

A seleção recorrente, termo que designa todo processo cíclico de melhoramento, tem, por objetivo, o melhoramento contínuo e progressivo das populações através do aumento das frequências dos alelos favoráveis dos caracteres sob seleção, que, normalmente, são aqueles de importância agronômica e econômica. Difere fundamentalmente de outros esquemas de seleção cíclica por pretender, além do melhoramento das populações, a manutenção da variabilidade genética em níveis adequados para permitir o melhoramento em ciclos subsequentes. É, portanto, um esquema seletivo para programas de melhoramento genético concebidos e planejados para médios e longos prazos. As populações escolhidas para os programas de seleção recorrente devem possuir, para os caracteres sob consideração, variabilidade genética em magnitude compativel com os progressos desejados. No decorrer do programa, a magnitude da variabilidade genética deverá ser monitorada a fim de se impedir a sua diminuição de forma drástica, fato que impossibilitaria a utilização da população por um prazo maior. As populações melhoradas via seleção recorrente podem ser usadas como variedades, como fontes de linhagens para a produção de híbridos ou ainda com duplo propósito, ou seja, com ambas as finalidades, o que irá definir as estratégias que deverão ser estabelecidas, observando-se os cuidados que deverão ser adotados para prevenir ou promover, intencionalmente, o surgimento e o incremento da endogamia (Souza Júnior, 1997). 
Os objetivos básicos de qualquer sistema de seleção recorrente são: (a) melhorar populações de uma maneira cíclica através do aumento das frequências de alelos e de combinações gênicas favoráveis e (b) manter adequada variabilidade genética para seleções posteriores. As populações melhoradas se constituirão em excelentes fontes de germoplasma para uso direto pelos agricultores como variedades de polinização livre ou para o desenvolvimento de linhagens para a síntese de híbridos. Sistemas de seleção recorrente incluem todos aqueles sistemas que repetem o mesmo procedimento ciclo após ciclo. O procedimento geralmente envolve (a) produção de um grupo de genótipos (indivíduos ou progênies de algum tipo), (b) avaliação dos genótipos produzidos em experimentos com repetições e identificação daqueles superiores para serem usados como parentais na geração seguinte e (c) intercruzamentos entre os genótipos selecionados com base nos experimentos para produzir a geração seguinte (Pandey \& Gardner, 1992).

Os esquemas de seleção recorrente são classificados em duas categorias: seleção recorrente intrapopulacional $\left(\mathrm{SR}_{\text {Intra }}\right)$ e seleção recorrente interpopulacional $\left(\mathrm{SR}_{\text {Inter }}\right)$, também denominada de seleção recorrente recíproca, originalmente proposta por Comstock et al. (1949). Na seleção recorrente intrapopulacional, o objetivo consiste em melhorar as performances per se das populações, enquanto que, na seleção recorrente interpopulacional, o objetivo é melhorar o cruzamento de duas populações, ou seja, a síntese do híbrido interpopulacional (Pandey \& Gardner, 1992; Souza Júnior, 1997).

Cada ciclo da seleção recorrente, com exceção da seleção massal, consiste de quatro fases distintas: obtenção de progênies, avaliação das progênies obtidas em experimentos com repetições, seleção das progênies superiores com base nas médias dos experimentos e recombinação das progênies selecionadas ou recombinação de outros tipos de progênies relacionadas àquelas selecionadas, ou seja, a unidade de seleção tanto pode ser a mesma progênie avaliada como pode ser alguma progênie relacionada àquela progênie selecionada (Pandey \& Gardner, 1992; Souza Júnior, 1997). 
A primeira fase da seleção recorrente, a obtenção de progênies, consiste na produção de progênies para serem avaliadas e na produção de progênies para serem recombinadas. Alguns esquemas utilizam o mesmo tipo de progênie como unidade de avaliação e unidade de recombinação, enquanto outros empregam um tipo de progênie como unidade de avaliação e um tipo diferente como unidade de recombinação. $\mathrm{O}$ uso de progênies permite avaliar os valores genotípicos das plantas através do comportamento fenotípico médio de seus descendentes. Como a avaliação é realizada em experimentos com repetições, o valor genotípico de cada planta torna-se mais preciso do que aquele que seria obtido apenas com uma avaliação individual, já que tal procedimento reduz a contribuição dos efeitos ambientais e residuais e das interações dos genótipos com os ambientes na determinação das médias das progênies (Souza Júnior, 1997).

O número de progênies que deverão ser obtidas e avaliadas deve ser decidido considerando-se dois aspectos principais: (a) as progênies retiradas da população precisam representá-la adequadamente, ou seja, a variabilidade genética expressa entre e dentro das progênies deve representar a variabilidade genética da população original e (b) a magnitude da intensidade de seleção deve ser bem observada, de forma a atenuar ou a evitar a ocorrência de oscilação genética, o que poderia implicar o surgimento do fenômeno da endogamia na população. A amostra não pode ser muito pequena, pois assim não representaria adequadamente a população, nem muito grande, pois acarretaria problemas ligados à experimentação. Poucos estudos, entretanto, foram conduzidos com o propósito de mensurar o tamanho apropriado da amostra (Lima Neto, 1994; Pinto, 1996).

A segunda etapa da seleção recorrente, a avaliação das progênies, é a fase mais crítica do processo por requerer maior quantidade de recursos e também por demandar mais tempo para a sua consecução. O número de repetições e de locais de avaliação dependerá da disponibilidade de sementes e, obviamente, de recursos para o programa de melhoramento. A etapa de avaliação é, portanto, bastante relevante, porque será responsável por uma efetiva discriminação das progênies (Souza Júnior, 1997). 
Chaves \& Miranda Filho (1992) conduziram um estudo sobre o tamanho adequado da parcela para a seleção de progênies de milho.

A seleção das progênies superiores é efetuada com base nas médias decorrentes dos experimentos com repetições. Como normalmente a pretensão de um programa de melhoramento é o melhoramento simultâneo de vários caracteres, deve-se empregar um índice que considere as peculiaridades de cada caráter, como também as correlações genéticas entre eles. A intensidade de seleção dependerá do número de progênies avaliadas, do tipo de progênie que constituirá a unidade de recombinação, da precisão experimental (expressa pelo coeficiente de variação experimental), dos fatores ambientais e também do planejamento do programa de melhoramento em questão. Assim, a intensidade de seleção é um parâmetro que pode ser estabelecido a priori apenas parcialmente, ou seja, pode-se estabelecer apenas o tamanho efetivo mínimo adequado que se deseja no programa (Souza Júnior, 1997).

A última etapa de um ciclo de seleção recorrente é a recombinação das progênies, as quais podem ser do mesmo tipo daquelas usadas como as unidades de avaliação ou de um tipo diferente. As progênies que se constituirão nas unidades de recombinação são provenientes das sementes remanescentes das plantas que forneceram as progênies selecionadas. As unidades de recombinação podem ser formadas por progênies de meios irmãos, de irmãos germanos, $\mathrm{S}_{1}$ e $\mathrm{S}_{2}$. Os tipos de progênie que serão escolhidos como unidades de seleção e como unidades de recombinação influirão diretamente nas respostas esperadas à seleção, tanto no processo de seleção recorrente intrapopulacional como no processo de seleção recorrente interpopulacional (Souza Júnior, 1989).

O objetivo da etapa da recombinação das progênies, para cada ciclo na seleção recorrente, é quebrar os blocos gênicos de ligação e permitir a recombinação genética para gerar novos genótipos e manter a variabilidade genética da população (na seleção recorrente intrapopulacional) ou a variabilidade genética das populações (na seleção recorrente interpopulacional), a qual poderá continuar a ser explorada nos ciclos seletivos seguintes (Pandey \& Gardner, 1992). 
Entretanto, a literatura não dispõe de trabalhos, em milho, que indiquem quantos ciclos de recombinação são necessários para romper os blocos de ligação e gerar variabilidade genética nas populações. Nos programas de seleção recorrente, geralmente apenas uma etapa de intercruzamentos entre as plantas é efetuada, com o intuito de evitar o prolongamento dos ciclos seletivos, já que uma etapa adicional de recombinação requereria maior dispêndio de tempo e de recursos. Uma geração de acréscimo em cada ciclo seletivo poderia, portanto, reduzir o ganho genético que seria obtido por ano (Souza Júnior, 1997). Em soja, experimentos com ênfase no processo de recombinação não comprovaram que múltiplas e sucessivas gerações de cruzamentos entre as plantas elevariam o ganho genético na seleção recorrente (Piper \& Fehr, 1987; Guimarães \& Fehr, 1989).

O melhoramento genético ao nivel interpopulacional iniciou-se com o trabalho de Comstock et al. (1949). Os autores sugeriram a seleção recorrente recíproca como um método para desenvolver simultaneamente duas fontes de germoplasma para programas de melhoramento do milho híbrido, já que o processo de seleção se baseia no comportamento do híbrido interpopulacional. No esquema de melhoramento proposto, genótipos de duas populações são avaliados em cruzamentos recíprocos. Os genótipos de cada população que apresentarem a melhor capacidade de combinação com a população recíproca serão portanto recombinados entre si. O fundamento é, assim, a seleção de uma população em função da sua capacidade de combinação com uma outra população e vice-versa.

Os estudos sobre a seleção recorrente em milho foram extensivamente ampliados por vários autores. Hallauer (1970) determinou a alteração relativa na variação genética após quatro ciclos de seleção recorrente recíproca para o caráter rendimento de grãos utilizando o delineamento II (Comstock \& Robinson, 1948). Estimativas da variância genética aditiva e da variância genética dominante foram obtidas em seis populações: as duas populações originais, nas quais a seleção para o referido caráter foi iniciada $\left(\mathrm{C}_{0}\right)$, as duas populações obtidas após quatro ciclos de seleção recorrente recíproca $\left(\mathrm{C}_{4}\right)$ e as duas populações formadas por cruzamentos dos dois materiais originais no ciclo inicial $\left(\mathrm{C}_{0}\right)$ e após os quatro ciclos de seleção $\left(\mathrm{C}_{4} \times \mathrm{C}_{4}\right)$. 
$\mathrm{O}$ autor constatou, porém, que as estimativas da variância aditiva decresceram e que as estimativas da variância dominante não se modificaram, tanto nas populações originais como na população híbrida, com os quatro ciclos de seleção recorrente recíproca. Houve um aumento no rendimento de grãos em uma das populações originais e na população híbrida, mas uma diminuição no caráter na outra população original. Entretanto, os ganhos genéticos verificados foram modestos.

Paterniani \& Vencovsky (1977) apresentaram uma modificação do procedimento original da seleção recorrente recíproca. Progênies de meios irmãos de uma população seriam testadas com a população recíproca, o que proporcionaria uma recombinação mais adequada entre as progênies de meios irmãos selecionadas. Duas populações de polinização aberta foram utilizadas. Através dos resultados de um ciclo, os autores verificaram que as duas populações e o híbrido $F_{1}$ interpopulacional aumentaram o rendimento de grãos em $6 \%, 6 \%$ e 7,5\%, respectivamente.

Paterniani \& Vencovsky (1978) apresentaram uma nova versão da seleção recorrente recíproca. Assim, para cada planta, duas progênies de meios irmãos seriam obtidas: uma progênie de meios irmãos interpopulacionais para ser avaliada e uma progênie de meios irmãos intrapopulacionais para ser recombinada, a fim de iniciar um novo ciclo. Três ciclos de seleção foram realizados envolvendo duas populações. Os ganhos genéticos por ciclo do híbrido resultante do cruzamento entre as duas populações apresentaram como média, para o caráter rendimento de grãos, o valor de $3,5 \%$.

Moll \& Smith (1981) apresentaram as variâncias genéticas e as respostas esperadas à seleção em uma geração avançada de um híbrido entre duas populações divergentes. Os experimentos consistiram em promover, na população híbrida, cinco ciclos de seleção com progênies de irmãos germanos e com progênies $S_{1}$ para $o$ rendimento de grãos, estimar as respostas aos dois métodos de seleção, caracterizar a variância genética antes e depois do processo seletivo e comparar as respostas esperadas baseadas nas estimativas das variâncias com as respostas observadas. Os autores notaram que a resposta à seleção recorrente com as progênies $S_{1}$ foi aproximadamente 50 \% maior que a resposta à seleção recorrente com as progênies de irmãos germanos. 
As respostas esperadas à seleção computadas a partir das estimativas das variâncias genéticas foram muito altas quando comparadas com as respostas observadas. A seleção resultou em uma redução na estimativa da variância genética de aproximadamente um terço.

Miranda Filho (1982) sugeriu esquemas de cruzamentos para mensurar a heterose na seleção recorrente recíproca. Dois esquemas de cruzamentos envolvendo dois tipos de progênie foram utilizados com a finalidade de obter estimativas da variância e da covariância genética entre progênies tanto ao nível intrapopulacional como ao nível interpopulacional. O primeiro esquema envolve progênies de meios irmãos de uma população e testcrosses de progênies de meios irmãos usando a outra população como um testador, enquanto o segundo esquema compreende progênies de meios irmãos intra e interpopulacionais. $\mathrm{O}$ autor forneceu as fórmulas para predição do ganho genético nas populações parentais e no cruzamento interpopulacional, o que permite uma previsão do ganho para heterose no híbrido intervarietal após a seleção recorrente recíproca.

Miranda Filho \& Paterniani (1983) avaliaram duas populações em relação ao potencial para o melhoramento através da seleção recorrente. Dois tipos de progênie foram usados: progênies de meios irmãos intrapopulacionais e testcrosses de progênies de meios irmãos interpopulacionais. Os autores constataram que a estimativa da variância genética aditiva interpopulacional foi quase $60 \%$ maior do que a estimativa média intrapopulacional.

Souza Júnior (1983) observa que, em programas de seleção recorrente recíproca, a diversidade genética é uma das condições para a escolha dos materiais, já que, além do melhoramento das populações per se, o método visa obter um aumento na heterose com os ciclos de seleção. O autor, assim como Souza Júnior \& Miranda Filho (1989), relata, para os caracteres peso de espigas, altura da planta e altura da espiga, estimativas de variâncias genéticas aditivas interpopulacionais cujas grandezas seriam suficientes para proporcionar progressos substanciais com a metodologia da seleção recorrente recíproca. Nos dois trabalhos mencionados, o potencial genético de duas populações de milho para a seleção recorrente intra e interpopulacional foi avaliado. 
Progênies de meios irmãos intra e interpopulacionais foram obtidas de cada população. Para o peso de espigas, alterações significativas na heterose via seleção poderiam ser esperadas. O progresso esperado na heterose foi de 1,54 gramas por planta via seleção recorrente recíproca com progênies de meios irmãos. Baseando-se nos progressos esperados por seleção para o peso de espigas e no comportamento das populações originais e do híbrido interpopulacional, os autores concluiram que os materiais apresentavam elevado potencial para o melhoramento intrapopulacional, bem como para a exploração da heterose em cruzamentos.

Hallauer (1984) apresentou resultados de ciclos de seleção recorrente recíproca baseada em progênies de irmãos germanos em duas populações, visando enfatizar a seleção para a capacidade específica de combinação. A seleção foi baseada no desempenho de progênies de irmãos germanos, enquanto as progênies $S_{1}$ provenientes dos parentais que forneceram as melhores progênies de irmãos germanos foram intercruzadas para sintetizar a população do próximo ciclo seletivo. O objetivo principal da pesquisa foi, assim, sumariar os resultados decorrentes de sete ciclos sucessivos de seleção recorrente recíproca com progênies de irmãos germanos nas duas populações originais e na população resultante da hibridação. A resposta direta na população decorrente do cruzamento entre as duas populações originais foi de $2 \%$ por ciclo para o rendimento de grãos, ao passo que as respostas correlacionadas nas duas populações originais foram de aproximadamente $2,5 \%$.

Moll \& Hanson (1984), usando duas populações, pretenderam comparar os efeitos da seleção recorrente intrapopulacional com os efeitos da seleção recorrente interpopulacional. As respostas das duas populações, para o caráter rendimento de grãos, após dez ciclos de seleção recorrente com progênies de irmãos germanos e de seleção recorrente recíproca, são reportados. As médias das respostas à seleção com progênies de irmãos germanos, por ciclo, foram, então, 3,5\% e 1,4\%, para as duas populações originais, e $2 \%$, para a população proveniente da hibridação, enquanto que as médias das respostas à seleção recíproca, por ciclo, foram 2,4\% e - $0,3 \%$, para as duas populações, e 2,7\%, para a população resultante da hibridação. 
Souza Júnior (1985) abordou os procedimentos para estimar o progresso genético esperado em linhagens via seleção recorrente intrapopulacional. O objetivo do trabalho foi fornecer procedimentos estatísticos que permitissem estimar o progresso genético esperado em linhagens endogâmicas $S_{1}$ e $S_{6}$ por meio da seleção recorrente intrapopulacional. Dois esquemas de acasalamentos envolvendo progênies de linhagens endogâmicas e progênies de meios irmãos foram utilizados. O autor forneceu, portanto, os procedimentos estatísticos, a interpretação das variâncias e das covariâncias genéticas entre progênies e também as fórmulas requeridas para a predição dos progressos esperados por meio da seleção intrapopulacional nas linhagens endogâmicas $\mathrm{S}_{1}$ e $\mathrm{S}_{6}$

Souza Júnior \& Miranda Filho (1985) enfocaram as alterações na heterose via seleção recorrente intra e interpopulacional. Os autores obtiveram as expressões de alteração de frequências gênicas via seleção interpopulacional e de alteração na heterose, via seleção, em função de frequências gênicas e de efeitos genotípicos.

Souza Júnior (1987) descreveu um novo esquema de seleção recorrente recíproca com progênies de meios irmãos obtidas alternadamente de plantas não endogâmicas $\left(\mathrm{S}_{0}\right)$ e de plantas endogâmicas $\left(\mathrm{S}_{1}\right)$, comparando-o teoricamente com outros esquemas já previamente descritos na literatura, a seleção recorrente recíproca com progênies de irmãos germanos (Hallauer \& Eberhart, 1970) e a seleção recorrente recíproca com progênies de meios irmãos empregando plantas prolíficas (Paterniani \& Vencovsky, 1978). O procedimento envolve assim duas fases. Na primeira fase, as espigas inferiores de plantas prolíficas de populações não endogâmicas dispostas em lotes contíguos são autofecundadas, enquanto que as espigas superiores são polinizadas por uma mistura de pólen da população recíproca e utilizadas para avaliação. $\mathrm{Na}$ segunda fase, as progênies $S_{1}$ de cada população correspondentes aos genótipos selecionados na fase anterior são misturadas e semeadas em blocos separados. Em plantas prolíficas, as espigas superiores são polinizadas por uma mistura de pólen da população recíproca, produzindo, de tal maneira, as progênies de meios irmãos interpopulacionais para serem avaliadas, enquanto as espigas inferiores são livremente polinizadas, produzindo, portanto, as progênies de meios irmãos intrapopulacionais. 
Após a seleção de genótipos na segunda fase, o processo é reiniciado. Dados da eficiência relativa demonstram que a metodologia proposta é muito mais eficaz que os esquemas previamente mencionados de seleção recorrente recíproca com progênies de irmãos germanos (Hallauer \& Eberhart, 1970) e com progênies de meios irmãos empregando plantas prolíficas (Paterniani \& Vencovsky, 1978).

Lamkey \& Hallauer (1987) conduziram um estudo objetivando comparar estimativas de herdabilidade, para o rendimento de grãos, utilizando variâncias entre progênies a partir de experimentos em sete programas de seleção recorrente. Os sete métodos aplicados incluíram, na seleção intrapopulacional, progênies de irmãos germanos, progênies de meios irmãos, progênies $S_{1}$, progênies $S_{2}$, testcrosses com um testador endogâmico e testcrosses com um testador de base ampla, enquanto, na seleção interpopulacional, progênies de irmãos germanos. As estimativas obtidas nas análises, para o coeficiente de herdabilidade, variaram de 53,3\% a 79,8\%.

Fischer et al. (1987) investigaram os efeitos da seleção recorrente visando reduzir o número de ramificações do pendão e também a densidade da área foliar acima da espiga em populações tropicais. Seis ciclos de seleção recorrente recíproca com progênies de irmãos germanos foram avaliados em três populações, objetivando estimar respostas diretas e respostas correlacionadas por seleção para os caracteres mencionados. Para o número de ramificações do pendão, os seis ciclos de seleção proporcionaram reduções no caráter de $44,4 \%, 51,7 \%$ e 42,8 \%, nas três populações avaliadas. Para a densidade da área foliar acima da espiga, os seis ciclos de seleção propiciaram reduções no caráter de $18,5 \%, 15,6 \%$ e $15,9 \%$, nas três populações estudadas.

Tanner \& Smith (1987) conduziram experimentos para avaliar e comparar as mudanças no caráter rendimento de grãos, em uma população, em dois programas de seleção recorrente após oito ciclos. Um programa foi baseado em progênies de meios irmãos enquanto o outro programa foi baseado em progênies $S_{1}$. Os autores notaram que os ganhos genéticos verificados para o rendimento de grãos, dos ciclos 0 a 4 , foram significativamente maiores no programa de seleção com progênies $S_{1}$, enquanto, dos ciclos 4 a 8 , os valores no referido programa decresceram, porém de forma irrelevante. 
No programa de seleção com progênies de meios irmãos, entretanto, os ganhos genéticos verificados nos ciclos 4 a 8 foram maiores do que aqueles apresentados nos ciclos 0 a 4. Os efeitos da oscilação genética, em decorrência da redução no tamanho populacional, foram significativos para o referido caráter nos dois métodos e, assim, confundiram as respostas à seleção observadas, especialmente nos ciclos 0 a 4 . Os ganhos genéticos ajustados para o fenômeno da deriva genética foram menores que os ganhos esperados nos dois programas avaliados.

Rodriguez \& Hallauer (1988) analisaram os efeitos da seleção recorrente, avaliando dez diferentes populações. Os autores pretenderam estimar as respostas esperadas à seleção e comparar a eficiência relativa de distintas estratégias para o melhoramento do caráter rendimento de grãos. Assim, as dez populações submetidas aos diferentes métodos e suas respectivas gerações $S_{1}$ foram analisadas. Respostas positivas à seleção para elevar o rendimento de grãos foram constatadas para todos os métodos avaliados, exceto para a seleção recorrente recíproca em uma população. A resposta média aos métodos de seleção intrapopulacional foi superior à resposta média aos métodos de seleção interpopulacional. A resposta verificada nas gerações $S_{1}$ foi similar à resposta nas populações não endogâmicas. A redução na depressão por endogamia foi de $12 \%$.

Crossa \& Gardner (1989) mensuraram respostas esperadas à seleção, para o rendimento de grãos, em ciclos de seleção recorrente com progênies de irmãos germanos em dez populações. Algumas populações não apresentaram melhoramento para o referido caráter ou apresentaram uma produção menor no ciclo seletivo final, tanto por causa da baixa intensidade de seleção como em virtude da forte pressão de seleção aplicada simultaneamente para vários caracteres. Os resultados indicaram que a variabilidade genética entre as progênies de irmãos germanos foi mantida através dos ciclos em todas as populações estudadas. A larga proporção da variância dos genótipos com os ambientes sobre a variância genética verificada na maioria das populações sugere que a resposta por ciclo de seleção para o caráter rendimento de grãos pode ser maximizada se os ambientes nos quais as progênies estiverem sendo avaliadas forem subdivididos e classificados em subgrupos similares. 
Helms et al. (1989a) observaram que se os métodos de seleção recorrente forem efetivos, a frequência dos alelos favoráveis nas populações deverá aumentar. Alterações casuais nas frequências alélicas podem também ocorrer se o tamanho efetivo populacional for pequeno, em decorrência dos efeitos da amostragem. Em milho, cultura na qual a ação gênica dominante é positiva para o caráter rendimento de grãos, a deriva genética, fenômeno que significa, pois, a mudança nas frequências alélicas devida à amostragem, provoca depressão por endogamia. Dois fenômenos principais devem operar para modificar a média populacional no decorrer de ciclos de seleção recorrente, os quais são o próprio processo seletivo atuando para aumentar o valor e a depressão por endogamia devida à deriva genética atuando para diminuir o valor. Estimativas dos efeitos da oscilação genética podem ser úteis em virtude da determinação do tamanho efetivo populacional adequado. Os autores conduziram um estudo visando comparar o progresso genético esperado entre a seleção recorrente recíproca e a seleção recorrente intrapopulacional com progênies de meios irmãos e progênies $S_{2}$, além de separar os efeitos da seleção dos efeitos da deriva genética, constatando que, para o melhoramento do caráter rendimento de grãos, tanto os efeitos devidos à seleção como os efeitos devidos à deriva genética não foram significativamente diferentes entre os métodos avaliados e que os efeitos da deriva genética foram relevantes e, portanto, devem ser considerados em programas de seleção recorrente a longo prazo.

Helms et al. (1989b) inferiram que o progresso genético a partir da seleção depende da magnitude da variância genética aditiva da população. O processo seletivo e a deriva genética são dois fenômenos biológicos que podem, além de modificar a média populacional através da mudança das frequências alélicas, alterar também a magnitude da variância genética em uma população no decorrer de ciclos de um programa de seleção recorrente. Os autores procuraram determinar se alterações na estimativa da variância genética aconteceriam no caráter rendimento de grãos em dois programas de seleção recorrente. Um programa consistiu em seleção recorrente recíproca enquanto o outro programa consistiu em sete ciclos de seleção com progênies de meios irmãos seguidos por três ciclos de seleção empregando progênies $S_{2}$ (Helms et al., 1989a). 
Evidências sugerem que a variância genética decresceu na população melhorada por seleção recorrente reciproca mas não na população melhorada por seleção recorrente com progênies de meios irmãos e com progênies $S_{2}$.

Stromberg \& Compton (1989) avaliaram dez ciclos de seleção recorrente com progênies de irmãos germanos em uma população de polinização livre. Os autores empregaram um critério de seleção baseado em um índice incluindo os caracteres rendimento de grãos, proporção de plantas eretas e proporção de plantas apresentando espigas. O rendimento de grãos cresceu $1,2 \%$ por ciclo, a proporção de plantas eretas aumentou $2,8 \%$ por ciclo e a proporção de plantas que apresentavam espigas mostrou em acréscimo de $0,1 \%$ por ciclo.

Tragesser et al. (1989) investigaram os efeitos da oscilação genética e do processo seletivo em cinco programas de seleção recorrente. Subpopulações podem ser usadas para distinguir os efeitos cumulativos da deriva genética dos efeitos da elevação da frequência dos alelos favoráveis por seleção recorrente. Assim, os efeitos da seleção e da deriva genética foram analisados, para o caráter rendimento de grãos, em algumas populações. Os autores constataram que os efeitos cumulativos da oscilação genética e da seleção são similares, entretanto são opostos no sinal. Nos ciclos iniciais de um processo de melhoramento por seleção recorrente, a deriva genética será um importante fator de alteração das frequências alélicas quando o tamanho efetivo populacional for pequeno.

Moll (1991) avaliou dezesseis ciclos de seleção recorrente com progênies de irmãos germanos, para o caráter rendimento de grãos, em duas populações, com o intuito de estimar respostas esperadas à seleção e alterações nas variâncias genéticas. Os ganhos genéticos devidos à seleção foram lineares para os dezesseis ciclos, em uma porcentagem de $2,4 \%$ por ciclo para uma população e de $4,5 \%$ por ciclo para a outra população. A variância genética aditiva não apresentou nenhuma tendência associada à seleção em uma das duas populações avaliadas, no entanto, na outra população, o autor verificou que o parâmetro declinou com o decorrer do processo seletivo para o referido caráter. 
Walters et al. (1991a) avaliaram uma população obtida após nove ciclos de seleção recorrente recíproca e uma outra população obtida após sete ciclos de seleção com progênies de meios irmãos e mais três ciclos de seleção com progênies $S_{2}$. Ambas provêm, entretanto, da mesma população original. Os autores objetivaram comparar o desempenho de progênies $S_{1}$ e o montante de variação genética presente entre tais progênies na população original, nas populações melhoradas através dos métodos mencionados e na população resultante da hibridação entre tais populações nos ciclos avançados, verificando que as progênies $S_{1}$ das populações melhoradas apresentaram significativos acréscimos no rendimento de grãos quando comparadas com as progênies $S_{1}$ da população original e que as progênies $S_{1}$ da população híbrida apresentaram heterose em relação ao parental superior para o referido caráter. As estimativas da variância genética obtidas a partir das progênies $S_{1}$ foram relevantes nos quatro materiais avaliados.

Walters et al. (1991b) observaram que uma metodologia efetiva na seleção recorrente para um determinado caráter quantitativo aumentará a frequência dos alelos favoráveis em uma população. Consequentemente, poucos alelos deletérios serão expressos para o caráter abordado quando a população for submetida a um processo de endogamia. Os autores conduziram, assim, um estudo visando comparar a performance na depressão por endogamia nas mesmas populações previamente mencionadas (Walters et al., 1991a), percebendo que as gerações $S_{1}$ das respectivas populações melhoradas produziram significativamente mais do que a geração $S_{1}$ da população original. A população híbrida revelou heterose em relação ao parental superior nas gerações $S_{0}$ e $S_{1}$. Diferenças entre as duas populações melhoradas e a população híbrida na depressão por endogamia para o rendimento de grãos foram não significativas.

Eyherabide \& Hallauer (1991a) estimaram respostas diretas e indiretas para oito ciclos de seleção recorrente recíproca com progênies de irmãos germanos em duas populações. Oito ciclos de seleção foram eficazes para elevar o caráter rendimento de grãos em $6,5 \%$ por ciclo, na população híbrida, em 3,0 \% por ciclo, em uma das populações originais, e em 1,6 \% por ciclo, na outra população original. 
Eyherabide \& Hallauer (1991b) objetivaram determinar as contribuições dos efeitos aditivos e de dominância nas respostas à seleção e estimar os efeitos da deriva genética após oito ciclos de seleção recorrente recíproca com progênies de irmãos germanos para o rendimento de grãos nas mesmas populações anteriormente mencionadas (Eyherabide \& Hallauer, 1991a). Significativa heterose para o referido caráter foi detectada na população híbrida entre as populações originais no ciclo 0 . A heterose nas populações híbridas aumentou com o processo seletivo e foi causada pelo acúmulo de alelos favoráveis em locos com ação gênica aditiva e dominante das duas populações e pela condição heterozigota de locos para os quais a oscilação genética havia causado fixação de alelos em uma das populações parentais. $\mathrm{O}$ melhoramento do caráter nas populações originais no decorrer dos ciclos de seleção foi atribuído principalmente aos locos com ação aditiva, em uma população, e aos locos com ação dominante, na outra população. Os efeitos devidos à deriva genética no rendimento de grãos foram significativos nas duas populações originais. De acordo com Smith (1979a; 1979b), a oscilação genética pode limitar a resposta à seleção nas populações parentais se pequenos tamanhos efetivos populacionais forem usados para a recombinação. Smith (1979a; 1979b; 1983) propôs um modelo para avaliar a resposta à seleção ajustada aos efeitos da deriva genética.

Lamkey (1992) discorreu sobre os resultados de cinqüenta anos de seleção recorrente em uma população. $\mathrm{O}$ autor observou ainda que a seleção recorrente é um procedimento cíclico do melhoramento designado a aumentar a frequência dos alelos favoráveis em uma população, elevando a sua performance e mantendo ainda a sua variabilidade genética. $\mathrm{O}$ aumento nas frequências dos alelos favoráveis elevará a probabilidade de obtenção de linhagens endogâmicas superiores para a sintese de híbridos. Treze ciclos de seleção recorrente foram avaliados. Os sete primeiros ciclos consistiram em seleção com progênies de meios irmãos e os seis ciclos posteriores consistiram em seleção com progênies $S_{2}$. A taxa média da resposta à seleção com progênies de meios irmãos para o rendimento de grãos foi de 3,9 \% por ciclo. Os ciclos de seleção com progênies $S_{\mathbf{2}}$ não melhoraram significativamente o rendimento de grãos na população. 
Schnicker \& Lamkey (1993) avaliaram os efeitos de onze ciclos de seleção na média, na variância genética e nas correlações entre caracteres em uma população híbrida. Os autores destacaram que a seleção recorrente recíproca é um procedimento designado para melhorar simultaneamente duas populações através da seleção para o desempenho no cruzamento interpopulacional. O rendimento de grãos apresentou um aumento de $6,46 \%$ após os onze ciclos de seleção, todavia a variância genética do caráter decresceu, embora as diferenças observadas entre os ciclos não tenham sido significativas. As correlações genéticas e fenotípicas não parecem ter se alterado após os ciclos. Os resultados indicaram que a seleção recorrente recíproca foi efetiva para elevar o desempenho médio da população híbrida mantendo ainda a variabilidade genética.

Keeratinijakal \& Lamkey (1993a) avaliaram as respostas diretas e indiretas de onze ciclos de seleção recorrente recíproca em duas populações. A resposta para o rendimento de grãos do cruzamento interpopulacional foi de $6,95 \%$ por ciclo. O caráter cresceu $1,94 \%$ por ciclo em uma das populações originais, contudo na outra população original não mudou significativamente. A heterose em relação à média das populações parentais apresentada pela população híbrida cresceu de $25,44 \%$ para $76,04 \%$ do ciclo 0 ao ciclo 11 .

Keeratinijakal \& Lamkey (1993b) desdobraram a resposta à seleção para o rendimento de grãos nos efeitos gênicos aditivos e dominantes, além de avaliar os efeitos da deriva genética, usando as mesmas populações mencionadas anteriormente (Keeratinijakal \& Lamkey, 1993a). Os resultados mostraram que a resposta à seleção ocorreu em locos que apresentavam ação gênica parcial a completamente dominante. $\mathrm{O}$ melhoramento em uma das populações originais foi devido a efeitos aditivos e de dominância, mas apenas efeitos de dominância foram importantes na outra população parental e também na população híbrida. Os autores concluíram, assim, que a seleção recorrente recíproca foi eficiente para melhorar a população híbrida e também que a depressão por endogamia devida à deriva genética limitou a resposta observada nas populações per se. 
Souza Júnior (1993) destaca que os métodos de seleção recorrente intra e interpopulacionais constituem os esquemas seletivos que têm sido utilizados para o melhoramento dos germoplasmas. Contudo, nem a seleção recorrente intra nem a seleção recorrente interpopulacional podem melhorar a taxas razoáveis os híbridos interpopulacionais e as populações per se simultaneamente. Assim, o autor conduziu um trabalho para investigar as limitações de métodos de seleção recorrente intra e interpopulacional e para introduzir um esquema modificado de seleção, comparando-o com a seleção recorrente inter e com a seleção recorrente intrapopulacional com progênies de meios irmãos. O estudo da efetividade de tais métodos de seleção no melhoramento das populações per se e do híbrido interpopulacional foi efetuado sob uma abordagem eminentemente teórica.

Souza Júnior et al. (1993) avaliaram o potencial de duas populações, para o melhoramento genético interpopulacional, analisando progênies de meios irmãos interpopulacionais. A estimativa da heterose para o peso de espigas foi de $19,23 \%$, em relação à média dos parentais, e de $17,86 \%$, em relação ao parental superior. O progresso estimado com a seleção recorrente recíproca foi de 7,69 \%, o que é uma demonstração de que havia variabilidade genética aditiva suficiente para permitir progresso substancial com seleção para uma ampla região. Os autores concluíram, portanto, que as populações avaliadas possuíam elevado potencial para programas de seleção recorrente reciproca.

Burgess \& West (1993) repararam que alguns ciclos de seleção recorrente conseguiram restabelecer o nível original do caráter rendimento de grãos em uma população submetida anteriormente a um processo de seleção, para redução da altura da espiga, que havia culminado em um substancial decréscimo do referido caráter. Assim, os autores conduziram um estudo para avaliar as respostas para quatro ciclos de seleção objetivando elevar o rendimento de grãos após dez ciclos de seleção visando reduzir a altura da espiga. Durante a seleção para redução da altura da espiga, o rendimento de grãos havia decaído 29 \%. Quatro ciclos de seleção recorrente conseguiram restaurar o rendimento de grãos para aproximadamente o mesmo nível da população antes da seleção para redução da altura da espiga. 
Landi \& Frascaroli (1993) conduziram quatro ciclos de seleção recorrente com progênies de irmãos germanos para o caráter rendimento de grãos em uma população $F_{2}$ derivada de um cruzamento. $O$ estudo foi designado para avaliar as respostas à seleção. Os autores observaram uma resposta média à seleção para o referido caráter de 7,3\% por ciclo.

Moll et al. (1994) compararam os incrementos devidos a quatorze ciclos de seleção recorrente com progênies de irmãos germanos e devidos a quatorze ciclos de seleção recorrente recíproca para o caráter rendimento de grãos, em uma população hibrida de duas variedades, e observaram também se a elevação em tal caráter seria acompanhada por aumentos paralelos na quantidade de matéria seca e no acúmulo de nitrogênio. Depois dos quatorze ciclos de seleção, os caracteres rendimento de grãos, quantidade de matéria seca e acúmulo de nitrogênio cresceram $23 \%, 12 \%$ e $4 \%$, respectivamente, com as progênies de irmãos germanos, e $27 \%, 21 \%$ e $10 \%$, respectivamente, com a seleção recorrente recíproca.

Stojsin \& Kannenberg (1994a) objetivaram comparar quatro métodos de seleção recorrente em cinco populações melhoradas por índices de desempenho, envolvendo, entre outros caracteres, o rendimento de grãos, separar os efeitos da seleção daqueles devidos à oscilação genética e estimar os efeitos gênicos aditivos e dominantes contribuindo para a resposta à seleção. Quatro procedimentos foram comparados: seleção espiga-por-fileira modificada, seleção com progênies de meios irmãos, seleção com progênies endogâmicas e seleção recorrente recíproca. Em geral, os índices de desempenho aumentaram concomitantemente com o rendimento de grãos. A resposta à seleção foi atribuída à mudança nas frequências de alelos em locos com ação predominantemente aditiva na seleção com progênies endogâmicas, dominante na seleção espiga-por-fileira modificada e tanto aditiva como dominante na seleção com progênies de meios irmãos e na seleção recorrente recíproca. Estimativas dos efeitos da deriva genética foram predominantemente de sinal oposto à direção da resposta à seleção e, em três das cinco populações, tais efeitos foram maiores na seleção com progênies endogâmicas. Os autores concluíram que não há um método de seleção que seja o melhor sob todas as circunstâncias. 
Stojsin \& Kannenberg (1994b) destacaram que a seleção recorrente em uma população pode resultar em alterações em determinados caracteres que não são aqueles empregados diretamente para critério de seleção. Tais alterações usualmente não podem ser facilmente previstas ou compreendidas porque não ocorrem de uma maneira sistemática e consistente. Assim, um estudo foi conduzido com o intuito de comparar alterações em caracteres indiretamente selecionados nas mesmas cinco populações anteriormente mencionadas sob os quatro métodos de seleção relatados (Stojsin \& Kannenberg, 1994a). Os autores concluiram que, em geral, a resposta à seleção indireta dependerá do método seletivo empregado, da média do caráter na população original e da correlação entre o caráter diretamente selecionado e o caráter indiretamente selecionado.

Pandey et al. (1994) conduziram um estudo envolvendo seis populações tolerantes e duas populações suscetiveis à acidez do solo, com o intuito de identificar germoplasma superior para desenvolver cultivares para solos ácidos. Os autores concluiram que a seleção recorrente reciproca seria efetiva para a consecução do objetivo, ou seja, desenvolver cultivares apropriados resistentes à acidez do solo.

Arias (1995) estimou componentes da variância e da covariância genética relacionados ao processo de seleção recorrente intra e interpopulacional em duas populações. Alguns esquemas de seleção recorrente foram estudados e comparados. As populações originais e o híbrido interpopulacional apresentaram produtividade elevada e um bom potencial para a produção de híbridos de linhagens.

Betran \& Hallauer (1996) testaram a seleção recorrente recíproca em duas populações. O objetivo do trabalho foi comparar a performance média relativa de cruzamentos entre as populações originais antes e após os ciclos seletivos. Os autores verificaram que houve um aumento significativo de $54,5 \%$ no rendimento de grãos da população híbrida após nove ciclos de seleção recorrente recíproca.

Takeda (1997) obteve três tipos de progênie em duas populações visando estimar os efeitos da seleção recorrente intra e interpopulacional em linhagens. $\mathrm{O}$ autor concluiu que os esquema de seleção recorrente interpopulacional, embora proporcionem ganhos menores às populações, propiciam a obtenção de linhagens mais produtivas. 
Fernandes (1990) já havia discorrido sobre as alterações que a seleção recorrente intra e interpopulacional acarreta em linhagens endogâmicas obtidas de populações sob o processo de seleção. O autor obteve, assim, diversas expressões para estimar o progresso genético esperado em tais linhagens, como também apresentou expressões para estimar a alteração na depressão por endogamia por ciclo de seleção recorrente intra e interpopulacional.

\subsection{DESEQULLIBRIO DE LIGAÇÃO}

Em uma grande população sob acasalamentos ao acaso, na ausência de migração, de mutação e de seleção, tanto as frequências gênicas como as frequências genotípicas são constantes de geração em geração e as frequências genotípicas são determinadas pelas frequências gênicas. Tal população encontra-se em equilíbrio de Hardy-Weinberg. Considerando-se apenas um loco, as frequências genotípicas de equilíbrio são estabelecidas após uma geração de acasalamentos ao acaso, sendo determinadas somente pelas frequências gênicas da população, independentemente das frequências genotípicas iniciais. Não há nenhuma tendência inerente para que tais frequências genotípicas sejam modificadas, assim, com o decorrer das sucessivas gerações de acasalamentos ao acaso (Mettler \& Gregg, 1969; Li, 1974; Crow, 1986; Hallauer \& Miranda Filho, 1988; Falconer, 1989).

A obtenção do equilíbrio nas frequências genotípicas depois de uma geração de acasalamentos ao acaso é verdadeira para os locos autossômicos considerados separadamente. No entanto, quando dois ou mais locos gênicos estão envolvidos, mesmo segregando-se independentemente, um número maior de gerações sucessivas de acasalamentos ao acaso é necessário para que o equilíbrio seja atingido para todos os locos do conjunto poligênico, embora cada loco, individualmente, necessite apenas de uma única geração de acasalamentos ao acaso para alcançar o equilíbrio (Mettler \& Gregg, 1969; Li, 1974).

Para dois locos com dois alelos, os gametas $A_{1} B_{1}, A_{1} B_{2}, A_{2} B_{1}$ e $A_{2} B_{2}$ formados pela população têm, como as frequências iniciais, $r, s, t$, e $u$, respectivamente. 
A expressão $r u$ - $s t$ corresponde à medida do afastamento do equilíbrio. Tal medida é reduzida à metade em cada geração de acasalamentos ao acaso, podendo, assim, ser considerada como um índice de divergência entre uma população arbitrária e uma população em equilíbrio ( $\mathrm{Li}, 1974)$. A aproximação ao equilibrio populacional será tanto mais lenta quanto maior for o número de locos considerados em conjunto, ou seja, à medida em que o número de locos em foco aumentar, progressivamente mais lenta será a aproximação ao equilíbrio (Falconer, 1989). A distribuição genotípica estável na população somente será atingida após uma única geração panmítica se tal população for composta exclusivamente de indivíduos heterozigotos para todos os pares do conjunto poligênico, desconsiderando, evidentemente, as ligações gênicas (Mettler \& Gregg, 1969).

Se, no entanto, dois locos gênicos estiverem ligados, a aproximação ao equilibrio populacional sob cruzamentos ao acaso dependerá da proximidade entre tais locos. Quando o equilíbrio for atingido, as fases de aproximação e de repulsão serão igualmente freqüentes na população. Em tal momento, a frequência dos tipos gaméticos dependerá somente das frequências gênicas. Quanto maior, portanto, a proximidade entre os locos, maior será o tempo necessário para uma população atingir o equilibrio, pois o aparecimento dos diversos possíveis genótipos dependerá da taxa de recombinação (Mettler \& Gregg, 1969; Falconer, 1989).

O desequilíbrio populacional relacionado a dois locos gênicos ligados é denominado desequilíbrio de ligação. Quando uma população em desequilíbrio de ligação apresenta os acasalamentos totalmente ao acaso, o montante do desequilíbrio é progressivamente reduzido a cada geração. $\mathrm{O}$ montante do desequilibrio de ligação em uma determinada geração $t$ é descrito pela expressão $D_{t}=D_{0}(1-r)^{t}$, em que $D_{0}$ é o desequilíbrio na geração inicial e $r$ representa a frequência de recombinação entre os dois locos ligados. Portanto, quanto maior for a frequência de recombinação entre os dois locos, significativamente menor será o montante do desequilíbrio na geração $t \mathrm{e}$ mais rápida será a aproximação ao equilíbrio. $\mathrm{O}$ desequilíbrio de ligação pode surgir em virtude do processo de seleção, em um programa de melhoramento genético, ou por causa da diminuição do tamanho efetivo populacional (Falconer, 1989). 
Mather \& Jinks (1982) discorreram sobre a influência do desequilíbrio de ligação nas estimativas dos componentes da variância genética. Em presença do desequilíbrio de ligação, a variância aditiva será $\mathrm{V}_{\mathrm{A}^{\prime}}=\mathrm{V}_{\mathrm{A}} \pm 2(1-2 \mathrm{r}) \mathrm{a}_{1} \mathrm{a}_{2}$, em que $\mathrm{V}_{\mathrm{A}}$ é a variância aditiva original, $r$ a fração de recombinação entre os locos ligados e $a_{l}$ e $a_{2}$ os efeitos médios dos genes dos locos ligados 1 e 2 , respectivamente, enquanto a variância dominante será $V_{D^{\prime}}=V_{D}+2(1-2 r)^{2} d_{1} d_{2}$, em que $V_{D}$ é a variância dominante original, $r$ a fração de recombinação entre os locos ligados e $d_{1}$ e $d_{2}$ os efeitos de dominância dos heterozigotos dos locos ligados 1 e 2 , respectivamente. Observando-se as expressões enunciadas, constata-se que tanto a magnitude na alteração da variância aditiva quanto a magnitude na alteração da variância dominante dependem da fração de recombinação entre os locos. Quanto maior a fração de recombinação, mais rápida será a aproximação ao equilíbrio e, portanto, menor será a alteração nos parâmetros mencionados. A variância aditiva poderá sofrer uma alteração tanto positiva quanto negativa. Se os locos ligados estiverem em fase de associação (acoplamento), o sinal da expressão será positivo e a variância aditiva sofrerá um acréscimo no seu valor. Se os locos ligados estiverem em fase de repulsão, o sinal da expressão será negativo e a variância aditiva sofrerá um decréscimo no seu valor. A variância dominante somente sofrerá uma alteração positiva no seu valor, independentemente da fase de ligação gênica (associação ou repulsão).

Falconer (1989) observa que o desequilíbrio de ligação introduz uma fonte adicional de variância genética. Considerando, assim, dois locos gênicos, G' e G" como os valores genotípicos de indivíduos relacionados a cada loco, separadamente, e ainda $G$ como o valor genotípico de indivíduos relativo a ambos, conjuntamente, pode-se inferir que $G=G^{\prime}+G^{\prime \prime}$. A variância genética total causada pelos dois locos juntos é expressa, assim, por $\mathrm{V}_{\mathrm{G}}=\mathrm{V}_{\mathrm{G}^{\prime}}+\mathrm{V}_{\mathrm{G}^{\prime}},+2 \mathrm{COV}_{\mathrm{G}^{\prime} \mathrm{G}^{\prime}}$. O termo da covariância representa a correlação entre os valores genotípicos dos dois locos. A correlação pode ser positiva ou negativa, assim o desequilíbrio de ligação pode tanto aumentar como também diminuir o valor da variância genética total. Quando mais de dois locos gênicos ligados estiverem sendo considerados, haverá, portanto, um termo da covariância específico para cada par de locos. Quando não houver desequilíbrio, todos os termos das covariâncias serão nulos. 
Os termos das covariâncias podem ser originados, assim, em razão do desequilíbrio de ligação.

Weir et al. (1980), em um estudo sobre os efeitos de ligações e do desequilíbrio de ligação nas covariâncias entre parentes não endogâmicos, também ressaltam que o desequilíbrio de ligação entre dois locos gênicos introduz uma covariância entre seus efeitos aditivos e entre seus efeitos de dominância. A covariância entre os efeitos aditivos será positiva ou negativa conforme a fase de ligação (associação ou repulsão, respectivamente). A covariância entre os efeitos de dominância será sempre positiva. Estimativas da variância genética aditiva e da variância genética dominante serão, assim, influenciadas, em virtude do surgimento de covariâncias entre os locos ligados.

O desequilíbrio de ligação afeta a covariância entre parentes. A influência das ligações gênicas nas covariâncias entre parentes foi primeiro investigada por Cockerham (1956), considerando apenas populações de cruzamentos ao acaso em equilíbrio de ligação. Schnell (1963) expôs um método geral para descrever os efeitos das ligações nas covariâncias entre parentes, em populações de cruzamentos ao acaso também em equilíbrio de ligação, concluindo, como Cockerham (1956), que as ligações podem afetar os componentes epistáticos das covariâncias entre parentes, mesmo que a população esteja em equilíbrio de ligação. Gallais (1974) também realizou um relevante estudo sobre os efeitos das ligações gênicas nas covariâncias entre parentes, considerando populações de cruzamentos ao acaso e populações endogâmicas sob desequilíbrio de ligação.

O desequilíbrio de ligação provoca o surgimento de correlações entre os caracteres. As ligações gênicas são uma causa genética transitória da correlação entre caracteres, particularmente em populações derivadas de cruzamentos entre linhagens divergentes. $\mathrm{O}$ desequilíbrio de ligação pode gerar problemas para o melhoramento, já que a seleção com base em um caráter pode causar alterações em outros. Contudo, o montante do desequilíbrio tende a ser dissipado com o avanço das gerações em uma população de acasalamentos ao acaso (Falconer, 1989). 
O desequilibrio de ligação pode surgir, portanto, em função do processo de seleção em um programa de melhoramento genético, implicando alterações nos componentes da variância genética. Falconer (1989) relata o fenômeno. A variância genética aditiva entre os indivíduos selecionados é $V_{A^{\prime}}=\left(1-h^{2} k\right) V_{A}$, em que $V_{A}$ é a variância aditiva na população antes da seleção, $h^{2}$ é a herdabilidade do caráter e $k$ é um fator que depende da intensidade da seleção. A redução da variância aditiva é uma conseqüência da covariância devida ao desequilibrio de ligação, representada, na equação, pelo termo correspondente $\mathrm{a}-\mathrm{h}^{2} \mathrm{kV}_{\mathrm{A}}$. Bulmer (1971) também discorreu sobre o processo (efeito Bulmer), mostrando que, mesmo na ausência de ligações, a seleção pode causar uma mudança apreciável na variância genética de um caráter por causa da correlação que surge entre pares de locos. A alteração, temporária e rapidamente reversível quando a seleção cessa, é, provavelmente, pequena sob uma intensidade de seleção encontrada em condições naturais, mas pode ser apreciável sob intensa seleção artificial. Bulmer (1974) estendeu os resultados incluindo os efeitos das ligações, sustentando que alterações na variância são efetivamente determinadas pelas frações de recombinação.

O desequilíbrio de ligação pode surgir, também, em função da diminuição do tamanho populacional (Hill \& Robertson, 1968; Karlin \& McGregor, 1968; Ohta, 1968; Ohta \& Kimura, 1969a; Ohta \& Kimura, 1969b; Sved, 1968; Sved, 1971; Ohta \& Kimura, 1971; Galley \& Curnow, 1972; Littler, 1973). Sved (1968) demonstrou que uma certa quantidade de desequilíbrio de ligação é esperada, independentemente de qualquer processo seletivo, em uma população de pequeno tamanho, tendo importantes consequiências na manutenção da variabilidade na seleção. Avery (1978), Yamazaki (1977), Felsenstein (1974) e Ohta \& Kimura (1970) discorreram sobre o desequilíbrio de ligação entre locos sobredominantes em populações finitas. Ohta \& Kimura (1970) incluiram, ainda, o reflexo da sobredominância associativa na manutenção da variabilidade genética em populações naturais. Hill (1974a; 1974b; 1975; 1976; 1977) analisou também o desequilíbrio de ligação envolvendo locos gênicos neutros em populações finitas. Brown (1975) avaliou tamanhos de amostras requeridos para detectar desequilíbrio de ligação entre dois ou três locos. 


\subsection{DESEQUILÍBRIO DE LIGAÇĀO E MELHORAMENTO}

\subsubsection{EFEITOS DO DESEQUILÍBRIO NAS ESTIMATIVAS DE VARIÂNCIAS GENÉTICAS}

Comstock \& Robinson $(1948 ; 1952)$ apresentaram alguns procedimentos experimentais para estimar variâncias genéticas e o grau médio de dominância em populações de plantas. Os autores destacam que, em presença do desequilibrio de ligação, as fases de repulsão gênica proporcionam o aparecimento de valores superestimados do grau médio de dominância. Contudo, os efeitos das ligações gênicas são dissipados através da recombinação genética ao longo das gerações de cruzamentos ao acaso, assim a pseudo-sobredominância decresce e desaparece com o avanço de tais gerações. Os autores fornecem as explicações teóricas para o fenômeno da pseudosobredominância. Quando dois locos gênicos estiverem ligados, uma covariância entre seus efeitos aditivos, a qual será positiva ou negativa a depender da fase de ligação, e uma covariância entre seus efeitos de dominância estarão presentes. Quando a fase de ligação gênica for predominantemente de associação, a covariância entre os efeitos aditivos será positiva, elevando assim o valor da variância genética aditiva. Quando a fase de ligação gênica for predominantemente de repulsão, a covariância entre os efeitos aditivos será negativa, diminuindo portanto o valor da variância genética aditiva. Para ambas as fases (associação e repulsão), entretanto, a covariância entre os efeitos de dominância será positiva.

Assim, nas gerações iniciais de um cruzamento entre duas linhagens contrastantes, portanto em presença do desequilibrio de ligação cujas fases estarão predominantemente em repulsão gênica, o grau médio de dominância, representado pela proporção dos efeitos de dominância sobre os efeitos aditivos, poderá acusar sobredominância, já que a variância genética aditiva estará subestimada e a variância genética dominante estará superestimada. Contudo, em presença do desequilíbrio de ligação cujas fases forem predominantemente de associação gênica, tanto a variância

genética aditiva como a variância genética dominante estarão igualmente inflacionadas. 
O grau médio de dominância não indicará, portanto, sobredominância. Com o avanço das gerações através de cruzamentos ao acaso, a recombinação entre os locos gênicos ligados proporcionará o alcance do equilibrio de ligação e, consequentemente, o desaparecimento da pseudo-sobredominância inicial (Comstock \& Robinson, 1948; Comstock \& Robinson, 1952).

A influência das ligações gênicas em fase de repulsão na obtenção de estimativas do grau médio de dominância também foi notada por alguns outros pesquisadores, como Hull (1952), Crow (1952) e Mangelsdorf (1952), em trabalhos eminentemente teóricos. Os autores teceram comentários sobre a possibilidade de simulação de sobredominância, para um determinado caráter, em virtude da presença de genes fortemente ligados em fase de repulsão.

Robinson et al. (1949) obtiveram estimativas para o grau médio de dominância, em milho, utilizando populações $F_{2}$ de três diferentes híbridos derivados de cruzamentos entre linhagens endogâmicas. Oito caracteres foram avaliados: altura da planta, altura da espiga, extensão da palha, escore da palha, número de espigas, comprimento da espiga, diâmetro da espiga e rendimento de grãos. Os caracteres altura da planta e altura da espiga indicaram pouca ou nenhuma dominância. $O$ caráter extensão da palha indicou completa dominância, enquanto os caracteres escore da palha, número de espigas, comprimento da espiga e diâmetro da espiga apresentaram parcial a completa dominância. A possibilidade de existência de sobredominância na ação de genes determinando o caráter rendimento de grãos foi indicada. Contudo, os autores frisaram que é teoricamente possível obter estimativas de sobredominância para genes que apresentam parcial dominância em decorrência de fortes ligações gênicas, em fases de repulsão, que não foram quebradas com apenas uma geração de cruzamentos ao acaso.

Robinson et al. (1955) apresentaram estimativas para a variância genética aditiva e para a variância genética dominante em três variedades de milho. Os caracteres quantitativos analisados pelos autores foram o número de dias para o florescimento, a altura da planta, a altura da espiga, o número de fileiras de grãos, o número total de espigas, o comprimento da espiga, o diâmetro da espiga e o rendimento de grãos. 
Estimativas da variância dominante foram baixas e, em alguns casos, foram até mesmo consideravelmente baixas, em comparação com as estimativas da variância aditiva, para todos os caracteres e nas três variedades. Os autores concluíram, em função das baixas estimativas da proporção da variância dominante sobre a variância aditiva, que locos com sobredominância não são uma importante fonte de variabilidade genética nas três variedades avaliadas, ressaltando, ainda, que as estimativas obtidas por Robinson et al. (1949) podem ter sido incrementadas pelas ligações gênicas.

Robinson et al. (1960) destacaram que, se as fases de ligação gênica forem predominantemente de repulsão, a variância genética aditiva crescerá com o avanço das gerações. Se forem predominantemente de associação, tal parâmetro decrescerá com o avanço das gerações. Os autores concluíram, também, a partir da geração $F_{2}$ e das gerações avançadas de populações de dois híbridos, em milho, analisando o caráter rendimento de grãos, que as ligações gênicas influenciam as estimativas da variância dominante. A redução na estimativa de tal parâmetro com o avanço das gerações, as quais proporcionam as recombinações, é consistente com a sugestão dos efeitos de ligação associados com a multiplicidade de locos. As baixas estimativas da variância aditiva nas gerações avançadas das populações dos híbridos usadas pelos autores, em comparação com aquelas que foram verificadas na geração $F_{2}$, sugerem, portanto, a preponderância de fases de associação nas respectivas gerações $\mathrm{F}_{2}$ dos dois híbridos. Os autores teceram, ainda, considerações sobre os resultados obtidos por Robinson et al. (1949) e por Robinson et al. (1955), ressaltando que fases de repulsão gênica poderiam ter provocado uma elevação nas estimativas da variância genética dominante obtidas nas gerações $\mathrm{F}_{2}$ provenientes dos cruzamentos entre linhagens endogâmicas analisadas por Robinson et al. (1949), fato que simularia uma ação de sobredominância dos genes envolvidos no caráter rendimento de grãos, enquanto que, nas variedades de polinização aberta analisadas por Robinson et al. (1955), as ligações gênicas já teriam sido quebradas e dissipadas ao longo das sucessivas gerações de cruzamentos ao acaso, fato que deve ter proporcionado a ocorrência das estimativas de baixa magnitude relativas à proporção da variância genética dominante sobre a variância genética aditiva para o rendimento de grãos. 
Gardner et al. (1953) estimaram o grau médio de dominância para dez caracteres quantitativos em milho. Duas populações $F_{2}$ descendentes do cruzamento entre linhagens homozigotas foram utilizadas na investigação. Duas amostras de progênies de cada uma das duas populações foram retiradas. Os dez caracteres quantitativos avaliados foram o rendimento de grãos, o número de espigas, 0 comprimento da espiga, o diâmetro da espiga, o número de fileiras de grãos, a altura da planta, a altura da espiga, o número de dias para o florescimento, o número de folhas e o comprimento da folha. Os resultados mostraram que o grau médio de dominância para a maioria dos caracteres variou da dominância parcial à completa. No entanto, para dois caracteres, o comprimento da espiga, em uma população, e o rendimento de grãos, nas duas populações, as estimativas forneceram forte evidência favorecendo a hipótese da sobredominância ou favorecendo a hipótese da existência de considerável ligação entre locos com ação gênica parcial a completamente dominante. Os autores enfatizaram, portanto, a necessidade de investigar gerações mais avançadas dos cruzamentos, a fim de inferir se as ligações gênicas causaram ou não uma elevação nas estimativas obtidas nas populações $F_{2}$.

Gardner \& Lonnquist (1959), utilizando populações $F_{2}$ e $F_{8}$ oriundas de um cruzamento entre duas linhagens homozigotas, em milho, obtiveram estimativas da variância genética aditiva, da variância genética dominante e do grau médio de dominância. Dados de uma segunda amostra da geração $F_{2}$ forneceram estimativas do grau médio de dominância para genes que controlavam o rendimento de grãos, indicando que tais genes apresentavam o fenômeno de sobredominância. Estimativas relativas à geração $\mathrm{F}_{8}$ indicaram, entretanto, apenas dominância completa. As estimativas verificadas para o grau médio de dominância e para a variância genética dominante foram, para todos os caracteres quantitativos estudados, inferiores na geração $\mathrm{F}_{8}$ quando comparadas com aquelas obtidas na segunda amostra da geração $\mathrm{F}_{2}$, sugerindo, assim, que as estimativas previamente obtidas para genes controlando o caráter rendimento de grãos, suscitando sobredominância, estavam superestimadas em decorrência de fases de repulsão entre locos ligados que apresentavam, na verdade, ação gênica situada apenas na faixa da dominância parcial ou da dominância completa. 
Graças a tais fases de repulsão, as estimativas da variância genética aditiva, na geração $F_{2}$, apresentaram-se subestimadas, enquanto que, na geração $F_{8}$, revelaram-se consistentemente altas. Há uma forte evidência de que as ligações gênicas foram quebradas ao longo das gerações de cruzamentos ao acaso, permitindo, assim, a ocorrência de recombinações e favorecendo, na geração $F_{8}$, o surgimento de novas combinações gênicas que não existiam na geração $F_{2}$. Os resultados obtidos, embora tenham indicado não mais que completa dominância para genes controlando o caráter rendimento de grãos (ou qualquer outro caráter quantitativo), não excluem, porém, a possibilidade de existência de uma ação gênica sobredominante em um ou mais locos. Entretanto, se a sobredominância possuísse uma importância considerável na determinação do rendimento de grãos, as estimativas do grau médio de dominância provavelmente permaneceriam constantes com o decorrer das gerações.

Gardner (1963) apresentou diversos experimentos envolvendo populações $F_{2}$, em milho, proporcionando algumas evidências favorecendo a hipótese da influência das ligações gênicas na obtenção de estimativas de parâmetros genéticos (variâncias genéticas e grau médio de dominância) e, assim, concluindo que a presença das ligações em fase de repulsão gênica provoca o aparecimento de estimativas do grau médio de dominância, obtidas em populações pouco avançadas de híbridos, na faixa da sobredominância. No entanto, diversas gerações de cruzamentos ao acaso permitem a quebra dos grupos de ligação, assim as populações híbridas alcançam o equilíbrio com respeito às fases das ligações gênicas. $\mathrm{O}$ autor sugeriu, ainda, que o grau médio de dominância para o caráter rendimento de grãos, em milho, encontra-se na amplitude da dominância parcial, hipótese que não excluiria, entretanto, a possibilidade de existência de ação gênica sobredominante em alguns locos, todavia tal fato não parece ser assim tão importante.

Moll et al. (1964) conduziram quatro experimentos, em milho, para obter estimativas do grau médio de dominância e também para investigar os efeitos das ligações gênicas nas estimativas de variâncias genéticas. As populações envolvidas no estudo eram gerações $F_{2}$ de dois diferentes cruzamentos e as respectivas gerações avançadas derivadas de cruzamentos totalmente ao acaso nas duas gerações $F_{2}$ iniciais. 
Os caracteres quantitativos estudados foram o rendimento de grãos, o número de espigas, o diâmetro da espiga, o comprimento da espiga, a altura da espiga, a altura da planta e o número de dias para o florescimento masculino. Os dois diferentes cruzamentos proporcionaram evidência de possivel sobredominância nas gerações $F_{2}$ para o rendimento de grãos. As gerações avançadas foram desenvolvidas através de cruzamentos ao acaso, visando assim permitir a ocorrência de recombinação genética com a subsequente dissipação da possivel pseudo-sobredominância verificada em virtude das ligações gênicas. Houve redução nas estimativas da variância dominante e do grau médio de dominância para todos os caracteres com os cruzamentos ao acaso, indicando, assim, que os efeitos das ligações haviam causado uma elevação nas estimativas obtidas nas populações $F_{2}$. Estimativas do grau médio de dominância para 0 rendimento de grãos, nas gerações avançadas, não foram significativamente diferentes de 1,0, o valor da dominância completa. Os autores concluíram que a sobredominância não é um tipo de ação gênica preponderante nas populações avaliadas. As conclusões estiveram de acordo com as considerações teóricas dos autores, os quais ponderaram que, na presença do desequilibrio de ligação, as fases de repulsão tendem a simular efeitos de sobredominância, os quais são indistinguiveis dos verdadeiros efeitos de sobredominância quando a frequência de recombinação é quase nula. Entretanto, os efeitos de uma pseudo-sobredominância, em contraste com os efeitos da verdadeira sobredominância, devem diminuir e até mesmo desaparecer gradativamente com a aproximação ao equilíbrio de ligação sob cruzamentos ao acaso a uma taxa proporcional à frequência de recombinação entre os locos gênicos.

Moreno-Gonzalez et al. (1975) avaliaram as gerações $F_{2}$ e $F_{6}$ provenientes de um cruzamento entre as linhagens de milho Illinois High Oil (IHO) e Illinois Low Oil (ILO), para o caráter porcentagem de óleo, objetivando: (1) Obter estimativas da variância genética aditiva e da variância genética dominante, como também do grau médio de dominância e (2) Medir o efeito da influência das ligações gênicas em tais estimativas. As conclusões obtidas foram as seguintes: (1) A estimativa da variância genética aditiva foi cerca de oito vezes maior que a estimativa da variância genética dominante na geração $F_{2}$, enquanto, na geração $F_{6}$, apenas cerca de quatro vezes maior; 
(2) A estimativa da variância genética aditiva na geração $F_{6}$ foi metade daquela obtida na geração $F_{2}$, sugerindo assim que muitos locos que controlavam o caráter porcentagem de óleo estavam ligados na fase de associação, nas linhagens parentais; (3) A estimativa da variância genética dominante na geração $F_{6}$ não diferiu daquela obtida na geração $F_{2}$, indicando uma ausência do efeito de ligações gênicas em tal parâmetro, fato que pode ser interpretado como um indício de que locos com ação dominante estavam distribuídos pelo genoma em distâncias cromossômicas que proporcionavam uma segregação independente ou, então, como um indício de que alguns de tais locos apresentavam dominância para baixa porcentagem de óleo, ao passo que outros apresentavam dominância para alta porcentagem de óleo e (4) Estimativas do grau médio de dominância foram 0,50 , para a geração $F_{2}$, e 0,68 , para a geração $F_{6}$ - as duas estimativas são significativamente diferentes de zero e de um, entretanto não diferem significativamente entre si.

\subsubsection{EFEITOS DO DESEQULIBRIO NO MELHORAMENTO}

Hanson (1959), utilizando o milho (Zea mays L.) como modelo, calculou a redução no tamanho de blocos de ligação parentais resultante da inclusão de gerações de intercruzamentos ao acaso, concluindo que três a quatro gerações são desejáveis para proporcionar adequada oportunidade para a recombinação e para estabelecer o equilíbrio de ligação antes de iniciar o processo de seleção. Assim, o autor propôs que um programa de melhoramento, para uma espécie de autofecundação, deva incluir no mínimo uma, mas preferencialmente três a quatro gerações de cruzamentos entre as plantas antes do início das autofecundações.

Hanson \& Hayman (1963) também conduziram uma investigação teórica em populações provenientes de cruzamentos entre parentais homozigotos com diferentes proporções de fases de associação gênica, concluindo que cruzamentos entre as plantas provavelmente diminuiriam a variância genética e a resposta imediata à seleção em programas de melhoramento. 
Pederson (1974) investigou o benefício esperado dos intercruzamentos em uma população $F_{2}$ originada do cruzamento entre parentais homozigotos, observando que tais intercruzamentos apenas são benéficos para dois locos se os alelos estiverem inicialmente em fase de repulsão gênica, conclusão estendida para mais de dois locos por simulação populacional. A teoria proposta sugere que, se as ligações estiverem predominantemente na fase de repulsão gênica, para um caráter governado por múltiplos locos, então os intercruzamentos promoverão as quebras de tais ligações, proporcionando um aumento na variância genética e na frequência relativa de homozigotos desejáveis, ou seja, na frequência relativa de genótipos contendo alelos ligados favoráveis, após repetidas autofecundações. Entretanto, se todos os possíveis arranjos dos alelos forem igualmente prováveis, então fases de associação gênica também ocorrerão e a manutenção das ligações na condição parental se constituirá uma vantagem, pois a quebra de tais fases predominantemente em associação gênica provocará um decréscimo na magnitude da variância genética em decorrência da redução na quantidade de genótipos que apresentariam tanto os alelos favoráveis como também os alelos desfavoráveis ligados. Bos (1977) também realizou uma abordagem sobre o tema, concluindo que a realização de intercruzamentos entre as plantas de uma geração $F_{2}$ não deverá propiciar um aumento na quantidade de indivíduos com genótipos desejados nas diversas culturas de autofecundação.

Alguns estudos em fumo (Nicotiana tabacum L.), sorgo (Sorghum bicolor L.) e trigo (Triticum aestivum L.) sugerem que cruzamentos ao acaso, seguidos por seleção, podem proporcionar aumento na recombinação genética, elevando assim as chances de obtenção de recombinantes desejáveis (Humphrey et al., 1969; Nordquist et al., 1973; Verma et al., 1979; Yunus \& Paroda, 1982). Legg et al. (1965) notaram, em fumo, que a produção decresceu, embora irrisoriamente, após avançadas gerações de cruzamentos ao acaso, mas acrescentaram que o decréscimo poderia ser facilmente superado por seleção. Matzinger \& Wernsman (1968), em fumo, e Redden \& Jensen (1974), em cereais, mostraram evidências de que intercruzamentos em gerações segregantes propiciam mudanças nas correlações genéticas em espécies autógamas. 
Meredith \& Bridge (1971) verificaram que tanto a média como a variância para o rendimento do linho decresceram após duas gerações de intercruzamentos em uma população de algodão (Gossypium hirsutum L.). Gerações de intercruzamentos apresentaram êxito na redução da associação negativa entre o rendimento do linho e a resistência da fibra em algodão, uma relação atribuída a fases de repulsão gênica (Miller \& Rawlings, 1967; Meredith \& Bridge, 1971). Entretanto, para um caráter individual como o rendimento, que deve apresentar tanto fases de repulsão como fases de associação gênica, gerações de intercruzamentos antes da seleção não parecem benéficas. Altman \& Busch (1984) também não encontraram evidência de aumento significativo na variância genética para o rendimento de grãos ou na frequência de recombinantes superiores após três gerações de intercruzamentos em três populações de trigo (Triticum aestivum L.). Os autores concluíram, portanto, que os benefícios proporcionados pelas recombinações genéticas foram inadequados para justificar a realização de intercruzamentos ao acaso, em populações $F_{2}$, como um procedimento preliminar, no melhoramento, antes da seleção.

O ganho genético na seleção recorrente é dependente dos procedimentos empregados nas quatro fases operacionais de cada ciclo: (1) obtenção de progênies para avaliação, (2) avaliação das progênies, (3) seleção das progênies superiores e (4) intercruzamentos das progênies selecionadas para formar a população para o próximo ciclo de seleção. O máximo ganho genético proporcionado pela seleção recorrente requer, portanto, uma eficiente e efetiva estratégia de seleção e de intercruzamentos dos genótipos superiores para formar uma nova população. Programas de seleção recorrente podem ser manipulados com o intuito de ressaltar a necessidade de investigar a extensão conveniente dos testes usados para identificar genótipos superiores e de elucidar o número necessário de gerações de intercruzamentos de tais genótipos entre os ciclos de seleção. Pesquisas conduzidas em soja (Glycine max L.) objetivaram comparar as respostas genéticas de estratégias alternativas da seleção recorrente para o caráter rendimento de grãos, visando, principalmente, determinar o ganho genético relativo com uma ou com três gerações de intercruzamentos entre os sucessivos ciclos seletivos. 
Os resultados indicaram que múltiplas gerações de intercruzamentos não elevaram o ganho genético (Piper \& Fehr, 1987; Guimarães \& Fehr, 1989).

Covarrubias-Prieto et al. (1989) observaram, em milho, uma significativa redução linear no rendimento de grãos, depois de seis gerações de cruzamentos ao acaso, em uma população $F_{2}$ formada por linhagens endogâmicas. Comparando a população $F_{2}$ e as cinco populações resultantes do avanço das gerações, constataram um acréscimo na variância genótipos $\mathrm{x}$ ambientes e na herdabilidade do caráter. Os autores concluíram, todavia, que não houve evidência de que os cruzamentos foram eficientes para aumentar a probabilidade de selecionar recombinantes desejáveis.

Han \& Hallauer (1989) também avaliaram os efeitos de cinco gerações de cruzamentos ao acaso nas populações $F_{2}$ geradas também pelas mesmas linhagens utilizadas por Covarrubias-Prieto et al. (1989) e por mais uma terceira. Os resultados mostraram pequena alteração na variância genética das populações per se após os cruzamentos ao acaso. As estimativas da variância genética aditiva permaneceram praticamente inalteradas, enquanto a variância genética dominante decresceu. Os autores concluíram que as cinco gerações de cruzamentos aleatórios não elevaram, assim, a variabilidade genética aditiva de forma considerável. A prática corrente de amostragem nas populações $F_{2}$, sem a recombinação genética adicional através de cruzamentos ao acaso, tem sido empregada com sucesso. Os dados sugerem que o tempo adicional e o esforço para a realização dos cruzamentos não são necessários. Os efeitos das ligações gênicas, tanto em fases de associação como em fases de repulsão, foram evidentes nas populações $F_{2}$ analisadas, uma vez que as estimativas do grau médio de dominância decresceram após as cinco gerações de cruzamentos ao acaso entre as plantas.

Mackay \& Gibson (1993) estenderam as fórmulas básicas para a predição de respostas à seleção a casos em que houver desequilíbrio gamético, demonstrando a importância da consideração dos efeitos de tal fenômeno na escolha entre esquemas alternativos de seleção recorrente aplicáveis a populações de plantas. Os autores, utilizando um exemplo com beterraba, concluíram que a desconsideração dos efeitos do desequilíbrio pode resultar assim em substancial superestimação de respostas à seleção. 
A seleção pode reduzir, portanto, a variação genética aditiva através da geração do desequilíbrio gamético, um fenômeno ainda desconhecido no melhoramento de plantas. Landi \& Frascaroli (1990) também destacaram que o declínio da variância genética pode resultar não apenas do desequilíbrio de ligação, mas também da seleção.

Lamkey et al. (1995), a partir de experimentos objetivando determinar a importância da epístase e a geração apropriada para o começo do desenvolvimento de linhagens endogâmicas, em milho, sugerem que não há vantagem em realizar intercruzamentos entre plantas de uma geração $F_{2}$ antes de iniciar a seleção e a autofecundação, pois as diferenças encontradas entre as gerações na variância genética e na herdabilidade, para o rendimento de grãos, não foram significativas. Os autores observam, entretanto, que cruzamentos ao acaso entre plantas em populações $F_{2}$ devem elevar a variância genética. A vantagem em intercruzar plantas antes da seleção e das autofecundações é quebrar os blocos de ligação, resultando em uma liberação de variação genética e presumivelmente em uma elevação na frequência de segregantes transgressivos. A desvantagem em intercruzar plantas antes de selecionar e autofecundar, contudo, é a possibilidade de ruptura, pela recombinação, de blocos favoráveis de genes ligados, acarretando assim um decréscimo na probabilidade de retenção de tais blocos nas progênies derivadas. Os autores acrescentam, ainda, que qualquer vantagem potencial oferecida pelos intercruzamentos deve ser ponderada pelo tempo necessário requerido. Para que os intercruzamentos sejam eficientes, o ganho genético proporcionado na população deve ser superior ao ganho genético que seria proporcionado por um período equivalente de seleção em uma população $F_{2}$. Embora, para alguns caracteres, algumas vantagens tenham ocorrido com os intercruzamentos, houve desvantagens maiores para o rendimento de grãos. O aumento observado na variância genética, com os intercruzamentos, foi devido principalmente a uma alta frequência de famílias segregando abaixo da média e a uma baixa frequência de famílias segregando acima da média, em comparação com a geração $F_{2}$. Baseados nas evidências sugeridas pelos experimentos, os autores não recomendam, portanto, a recombinação precedendo a seleção e a autofecundação em populações $\mathrm{F}_{2}$ de milho. 
Na seleção recorrente, a etapa da recombinação dos genótipos selecionados tem como objetivo a geração de variabilidade genética para ser aproveitada no próximo ciclo seletivo (Souza Júnior, 1989; Souza Júnior, 1997). No entanto, a população oriunda do processo da recombinação, ou seja, a população melhorada, está em desequilíbrio de ligação, o qual pode alterar os componentes da variância genética, especialmente a variância aditiva, que, a depender das fases de ligação gênica, pode sofrer uma diminuição e, consequentemente, comprometer a resposta à seleção. $\mathrm{O}$ próprio processo de seleção, gerando desequilíbrio de ligação, pode promover modificações na variância aditiva, reduzindo seu valor (Bulmer, 1971; Bulmer, 1974; Falconer, 1989; Mackay \& Gibson, 1993).

Para programas de obtenção de linhagens empregando populações $F_{2}$, em milho, os resultados experimentais na literatura mostram que não há necessidade de promover a recombinação antes de iniciar o processo de seleção e de autofecundação das plantas (Han \& Hallauer, 1989; Covarrubias-Prieto et al., 1989; Lamkey et al., 1995). Para programas de seleção recorrente em espécies alógamas, como o milho, não há estudos quantificando efeitos de ciclos adicionais de recombinação gênica (Souza Júnior, 1998) ${ }^{1}$. Resultados experimentais relatados em soja, uma espécie autógama, indicaram que gerações adicionais de recombinação entre os sucessivos ciclos seletivos, em programas de seleção recorrente, não elevaram a resposta à seleção e, por conseguinte, não devem ser aconselhadas como uma metodologia eficiente para vir a integrar os programas de melhoramento genético das plantas (Piper \& Fehr, 1987; Guimarães \& Fehr, 1989).

\footnotetext{
'Souza Júnior, C. L. (Escola Superior de Agricultura "Luiz de Queiroz"/USP, Piracicaba, SP). Comunicação pessoal.
} 


\section{MATERIAL E MÉTODOS}

\subsection{MATERIAL}

A população de milho ESALQ-PB 4 utilizada neste trabalho encontra-se sob seleção recorrente recíproca com a população de milho ESALQ-PB 5. Ambas possuem ciclo intermediário e plantas baixas, sendo que a população ESALQ-PB 4 apresenta grãos amarelos dentados e a população ESALQ-PB 5 apresenta grãos flints alaranjados. As populações foram desenvolvidas pelo Departamento de Genética da Escola Superior de Agricultura "Luiz de Queiroz" / USP. A população ESALQ-PB 4 é resultante do intercruzamento das populações Tuxpeño Crema I, MEB I e Antígua GP02 e a população ESALQ-PB 5 foi formada a partir do intercruzamento das populações Eto Blanco, Piracar e Mezcla Amarilla (Sampaio, 1986). O híbrido duplo comercial XL-510 da Empresa Braskalb Agrícola, apresentando ciclo intermediário com grãos alaranjados semidentados, foi utilizado como testemunha.

O processo de seleção recorrente recíproca que está sendo utilizado é descrito a seguir. Um campo com duas mil plantas da população ESALQ-PB 4 e um campo com duas mil plantas da população ESALQ-PB 5 foram plantados em lotes contíguos. Por ocasião do florescimento, uma intensa seleção para altura da planta, para altura da espiga e também para ausência de doenças foi praticada. Em cerca de quinhentas plantas selecionadas da população ESALQ-PB 4, as espigas inferiores foram autofecundadas e as espigas superiores foram polinizadas por uma mistura de pólen da população recíproca. Cada planta gerou, portanto, dois tipos distintos de progênie: uma progênie de meios irmãos interpopulacionais, que se constituiu na unidade de avaliação e de seleção, e uma progênie $S_{1}$, que se constituiu, por sua vez, na unidade de recombinação. 
Por ocasião da colheita, as plantas acamadas ou quebradas foram descartadas, assim como as espigas que apresentavam doenças. Duzentas progênies de meios irmãos interpopulacionais foram avaliadas em experimentos com duas a três repetições em dois a três ambientes, enquanto as progênies $S_{1}$ foram armazenadas em câmara seca. $A$ seleção das progênies foi baseada nos seguintes caracteres: produtividade, altura da planta (AP), altura da espiga (AE), relação (AE/AP), acamamento e quebramento. A intensidade de seleção das progênies foi de $10 \%$. As vinte progênies superiores de meios irmãos interpopulacionais foram, portanto, selecionadas. A recombinação com as progênies $S_{1}$ foi realizada através de linhas com vinte plantas. Assim, como vinte progênies $S_{1}$ (provenientes das plantas que forneceram as vinte melhores progênies de meios irmãos interpopulacionais) participaram do processo de recombinação, cada planta presente em uma linha pertencia a uma das vinte progênies envolvidas. Havia, no total, cem linhas. Intercruzamentos dentro das linhas foram praticados e a mistura eqüitativa de sementes das espigas polinizadas gerou a população do novo ciclo de melhoramento (primeiro ciclo de recombinação).

Para este trabalho, uma geração adicional de recombinação na população ESALQ-PB 4 no segundo ciclo de seleção recorrente recíproca foi realizada. De cada espiga colhida da primeira recombinação, uma semente foi retirada. Cerca de duas mil sementes foram, portanto, obtidas, originando, assim, cerca de duas mil plantas, das quais quinhentas foram polinizadas ao acaso. As plantas doadoras de pólen foram empregadas apenas uma vez e apenas como machos, enquanto as plantas polinizadas foram utilizadas apenas como fềmeas. As polinizações foram efetuadas em intervalos de três dias para evitar a seleção de plantas precoces e nenhuma seleção para os demais caracteres foi praticada. A mistura eqüitativa das sementes das quinhentas plantas polinizadas originou a população do segundo ciclo de recombinação.

No ano agrícola seguinte (1991/92), quinhentas sementes do primeiro ciclo de recombinação e quinhentas sementes do segundo ciclo de recombinação foram plantadas, originando quinhentas plantas de cada recombinação. Via polinização manual, cem progênies de meios irmãos e cem progênies de irmãos germanos de cada ciclo de recombinação foram obtidas, totalizando-se, portanto, quatrocentas progênies. 
Deve-se ressaltar que nenhum tipo de seleção foi praticado para a obtenção das progênies, bem como que as polinizações foram feitas de três em três dias para evitar a seleção para precocidade.

\subsection{EXECUÇÃO EXPERIMENTAL}

O presente trabalho reuniu, portanto, um total de quatrocentas progênies intrapopulacionais. Das quatrocentas progênies, cem eram progênies de meios irmãos com um ciclo de recombinação, cem eram progênies de irmãos germanos com um ciclo de recombinação, cem eram progênies de meios irmãos com dois ciclos de recombinação e cem eram progênies de irmãos germanos com dois ciclos de recombinação.

As progênies foram igualmente distribuídas em quatro experimentos, de tal forma que cada experimento continha cem progênies, das quais vinte e cinco eram progênies de meios irmãos com um ciclo de recombinação, vinte e cinco eram progênies de irmãos germanos com um ciclo de recombinação, vinte e cinco eram progênies de meios irmãos com dois ciclos de recombinação e vinte e cinco eram progênies de irmãos germanos com dois ciclos de recombinação. Os experimentos consistiam em látices $10 \times 10$ com duas repetições.

Os experimentos foram instalados em três ambientes: na área experimental Caterpillar nos anos agrícolas 1992/93 e 1993/94 e na área experimental Areião no ano agrícola 1992/93. As duas áreas experimentais pertencem ao Departamento de Genética da Escola Superior de Agricultura "Luiz de Queiroz" / USP.

As parcelas foram constituídas por fileiras de quatro metros, as quais estavam espaçadas entre si por um metro. O espaçamento entre as plantas dentro das parcelas foi de vinte centímetros. Depois da prática do desbaste, as parcelas apresentavam cerca de vinte plantas, o que corresponde, portanto, a um estande de cinqüenta mil plantas por hectare. 


\subsection{CARACTERES AVALIADOS}

\section{- Peso de espigas por parcela (PE)}

Através do peso de espigas despalhadas, o peso total de cada parcela foi obtido, em gramas. Antes da pesagem, as espigas foram postas para secar, a fim de uniformizar o teor de umidade. Os dados foram corrigidos para o estande médio de cada experimento através da análise de covariância, de acordo com a metodologia sugerida por Vencovsky \& Barriga (1992). Em seguida, o peso de cada parcela foi dividido pelo número médio de plantas por parcela, obtendo-se, assim, o peso de espigas por planta (g/planta).

\section{- Altura da planta (AP)}

A altura da planta correspondeu à distância, em centímetros, da superfície do solo ao local de inserção da última folha. Em cada parcela, cinco plantas foram aleatoriamente tomadas e uma média entre os cinco valores foi calculada.

\section{- Altura da espiga (AE)}

A altura da espiga correspondeu à distância, em centímetros, da superfície do solo ao nó de inserção da espiga superior. As cinco plantas de cada parcela que forneceram os valores da altura da planta foram tomadas para o recolhimento dos valores da altura da espiga. Também uma média entre os cinco valores foi obtida.

\section{- Posição relativa da espiga (PR)}

A posição relativa da espiga, caráter adimensional, correspondeu, em cada parcela, ao quociente entre a altura média da espiga e a altura média da planta.

- Índice de espigas (IE)

$\mathrm{O}$ índice de espigas, caráter também adimensional, representou, para cada parcela, o quociente entre o número total de espigas produzidas e o número total de plantas (estande). 


\subsection{ANÁLISES ESTATÍSTICAS}

As análises de variância foram realizadas para os quatro experimentos, individualmente. Em seguida, as quatro análises de variância individuais foram agrupadas. O procedimento foi realizado tanto para cada ambiente, separadamente, como para os três ambientes juntos (análises conjuntas). As análises de covariância foram realizadas da mesma forma, porém apenas envolvendo os três ambientes, conjuntamente, considerando-se todas as combinações possíveis entre os cinco caracteres avaliados, totalizando-se, assim, dez combinações.

\subsubsection{ANÁLISES DE VARIÂNCIA}

\subsubsection{ANÁLISES DE VARIÂNCIA POR AMBIENTE}

Para cada ambiente e para os cinco caracteres avaliados, as quatro análises de variância individuais foram, portanto, realizadas. O modelo estatístico para cada análise individual, considerado aleatório, foi:

$$
Y_{i j k}=m+p_{i}+b_{j(k)}+r_{k}+e_{i j k}
$$

em que:

$Y_{\mathrm{ijk}}$ é a observação referente à progênie $i$ no bloco $j$ da repetição $k$;

$\mathrm{m}$ é a média geral do experimento;

$\mathrm{p}_{\mathrm{i}}$ é o efeito da progênie $i$;

$\mathrm{b}_{\mathrm{j}(\mathrm{k})}$ é o efeito do bloco $j$ dentro da repetição $k$;

$\mathrm{r}_{\mathrm{k}}$ é o efeito da repetição $k \mathrm{e}$

$\mathrm{e}_{\mathrm{ijk}}$ é o erro associado à parcela $i j k$.

A fonte de variação geral para todas as progênies foi decomposta para as quatro classes de progênie (meios irmãos 1, meios irmãos 2, irmãos germanos $1 \mathrm{e}$ irmãos germanos 2) e para os diferentes grupos. Em seguida, as quatro análises de variância individuais por ambiente foram agrupadas através do somatório das somas dos quadrados e dos graus de liberdade de todas as fontes de variação contidas nas análises. 
O esquema das análises de variância individuais e também o esquema das análises de variância agrupadas por ambiente estão assim apresentados respectivamente nas Tabelas 1 e 2 .

Para cada análise agrupada realizada por ambiente, o coeficiente de variação experimental $\left(\mathrm{CV}_{\mathrm{e}}\right)$ foi calculado, de acordo com a seguinte fórmula, em porcentagem

$(\%): \mathrm{CV}_{\mathrm{e}}(\%)=\left(\frac{\sqrt{Q M_{E}}}{\bar{x}}\right) 100$, em que $\mathrm{QM}=$ quadrado médio do erro experimental $\mathrm{e}$ $\bar{x}=$ média geral experimental.

Para as análises agrupadas por ambiente, além do coeficiente de variação experimental e da média geral, as médias das quatro classes de progênie (meios irmãos 1 , meios irmãos 2 , irmãos germanos 1 e irmãos germanos 2) foram calculadas, assim como as médias dos dois ciclos de recombinação (primeiro e segundo) e as médias dos dois tipos de progênie (meios irmãos e irmãos germanos), visando assim verificar se o processo da recombinação adicional propiciaria alguma alteração estatisticamente significativa.

\subsubsection{ANÁLISES DE VARIÂNCIA CONJUNTAS}

Depois das análises de variância individuais realizadas para cada ambiente, separadamente, análises conjuntas foram realizadas, reunindo-se os três ambientes estudados. Assim, para cada experimento, uma análise conjunta foi realizada. Os ambientes foram considerados aleatórios e constituem anos e locais representativos da região de Piracicaba. O teste de homocedasticidade dos quadrados médios, proposto por Gomes (1990), foi aplicado, indicando, portanto, que havia a possibilidade de realização das análises conjuntas. O modelo estatístico para cada análise conjunta, considerado aleatório, foi:

$$
Y_{i j k l}=m+p_{i}+b_{j(k l)}+r_{k(l)}+a_{l}+(p a)_{i l}+e_{i j k l}
$$

em que: 
$Y_{\mathrm{ijkl}}$ é a observação referente à progênie $i$ no bloco $j$ da repetição $k$ no ambiente $l$;

$\mathrm{m}$ é a média geral do experimento;

$\mathrm{p}_{\mathrm{i}}$ é o efeito da progênie $i$;

$b_{\mathrm{j}(\mathrm{kl})}$ é o efeito do bloco $j$ dentro da repetição $k$ no ambiente $l$;

$\mathrm{r}_{\mathrm{k}(\mathrm{l})}$ é o efeito da repetição $k$ no ambiente $l$;

$a_{1}$ é efeito do ambiente $l$;

(pa) il é o efeito da interação da progênie $i$ com o ambiente $l$ e

$\mathrm{e}_{\mathrm{ijkl}}$ é o erro associado à parcela $i j k l$.

A fonte de variação geral para todas as progênies foi decomposta para as quatro classes de progênie (meios irmãos 1 , meios irmãos 2 , irmãos germanos 1 e irmãos germanos 2) e para os diferentes grupos, assim como a fonte de variação geral para as interações dos ambientes com todas as progênies foi decomposta para as interações dos ambientes com as quatro classes de progênie (meios irmãos 1, meios irmãos 2, irmãos germanos 1 e irmãos germanos 2) e para as interações dos ambientes com os diferentes grupos. Em seguida, as quatro análises de variância conjuntas foram agrupadas, através do somatório das somas dos quadrados e dos graus de liberdade de todas as fontes de variação contidas nas análises. O esquema das análises de variância conjuntas por experimento e o esquema da análise de variância conjunta agrupada estão apresentados respectivamente nas Tabelas 3 e 4 .

$\mathrm{O}$ teste $\mathrm{F}$ para a fonte de variação Ambientes/Experimentos (Tabela 4) é um teste composto, logo os graus de liberdade do numerador $\left(n_{1}\right)$ e do denominador $\left(n_{2}\right)$ são, respectivamente (Vencovsky \& Barriga, 1992):

$$
\begin{aligned}
& \mathrm{n}_{1}=\frac{\left(Q M_{A}+Q M_{E}\right)^{2}}{\frac{Q M_{A}^{2}}{8}+\frac{Q M_{E}^{2}}{972}} \mathrm{e} \\
& \mathrm{n}_{2}=\frac{\left(Q M_{R}+Q M_{P A}\right)^{2}}{\frac{Q M_{R}^{2}}{12}+\frac{Q M_{P .4}^{2}}{792}},
\end{aligned}
$$

em que: 
$\mathrm{QM}_{\mathrm{A}}=$ quadrado médio dos Ambientes/Experimentos (E),

$\mathrm{QM}_{\mathrm{E}}=$ quadrado médio do Erro médio experimental,

$\mathrm{QM}_{\mathrm{R}}=$ quadrado médio das Repetições/Ambientes/Experimentos (E) e

$\mathrm{QM}_{\mathrm{PA}}=$ quadrado médio das Interações (Progênies $\mathrm{x}$ Ambientes) / $\mathrm{E}$.

Para a análise conjunta agrupada, além da média geral experimental, as médias das quatro classes de progênie (meios irmãos 1 , meios irmãos 2, irmãos germanos 1 e irmãos germanos 2) foram calculadas, assim como as médias dos dois ciclos de recombinação (primeiro e segundo) e as médias dos dois tipos de progênie (meios irmãos e irmãos germanos), visando verificar se o processo da recombinação adicional proporcionaria ou não alguma alteração estatisticamente significativa.

\subsubsection{ESTIMATIVAS DOS PARÂMETROS GENÉTICOS}

Os parâmetros genéticos estimados para os cinco caracteres avaliados a partir da análise de variância conjunta agrupada foram os seguintes, obtidos de acordo com os procedimentos descritos por Vencovsky \& Barriga (1992):

- Variância genética de progênies $\left(\sigma_{P}^{2}\right)$ :

$\sigma_{P}^{2}=\frac{Q M_{P}-Q M_{P A}}{j k}$

- Variância das interações de progênies com ambientes $\left(\sigma_{P_{A}}^{2}\right)$ :

$\sigma_{P A}^{2}=\frac{Q M_{P A}-Q M_{E}}{j}$ 
- Variância do erro experimental $\left(\sigma_{E}^{2}\right)$ :

$\sigma_{E}^{2}=\mathrm{QM}_{\mathrm{E}}$

- Variância fenotípica de médias de progênies $\left(\sigma_{\bar{F}}^{2}\right)$ :

$\sigma_{\bar{F}}^{2}=\frac{Q M_{P}}{j k}$

- Herdabilidade ao nível de médias de progênies $\left(h_{x}^{2}\right)$ :

$$
h_{x}^{2}=\frac{\sigma_{P}^{2}}{\sigma_{\bar{F}}^{2}}
$$

- Resposta esperada à seleção entre progênies $\left(\mathrm{R}_{\mathcal{S}}\right)$ :

$$
\mathrm{R}_{\mathrm{S}}=\mathrm{i}\left(\frac{\sigma_{P}^{2}}{\sqrt{\sigma_{\bar{F}}^{2}}}\right),
$$

em que $\mathrm{i}=1,75$ corresponde ao diferencial de seleção estandardizado, referente a uma intensidade de seleção de $10 \%$.

Em termos percentuais,

$$
\mathrm{R}_{\mathrm{S}}(\%)=\left(\frac{R s}{\bar{x}}\right) 100 \text {, em que } \bar{x} \text { é a média experimental. }
$$


Nas expressões, $\mathrm{QM}_{\mathrm{P}}, \mathrm{QM}_{\mathrm{PA}}, \mathrm{QM}_{\mathrm{E}}, j$ e $k$ referem-se, respectivamente, ao quadrado médio das progênies, ao quadrado médio das interações das progênies com os ambientes, ao quadrado médio do erro experimental, ao número de repetições por ambiente e ao número de ambientes nos quais os experimentos foram instalados.

Entretanto, para cada caráter avaliado, há quatro classes de progênie: progênies de meios irmãos com um ciclo de recombinação, progênies de irmãos germanos com um ciclo de recombinação, progênies de meios irmãos com dois ciclos de recombinação e progênies de irmãos germanos com dois ciclos de recombinação. Assim, cada classe de progênie terá a sua própria variância genética $\left(\sigma_{P}^{2}\right)$, a sua própria variância das interações com ambientes $\left(\sigma_{P A}^{2}\right)$, a sua própria variância fenotípica de médias $\left(\sigma_{\bar{F}}^{2}\right)$, a sua própria herdabilidade ao nível de médias $\left(h_{x}^{2}\right)$ e a sua própria resposta esperada à seleção ( $R_{S}$, tanto na unidade do caráter considerado - ou ainda em valor absoluto - como em percentual da média).

Além dos parâmetros genéticos mencionados, o coeficiente de variação experimental $\left(\mathrm{CV}_{\mathrm{e}}\right)$ e o coeficiente de variação genética $\left(\mathrm{CV}_{\mathrm{g}}\right)$, ambos em porcentagem (\%), também foram estimados, de acordo com as seguintes expressões, para a análise de variância conjunta agrupada:

$$
\begin{aligned}
& \mathrm{CV}_{\mathrm{e}}(\%)=\left(\frac{\sqrt{\sigma_{E}^{2}}}{\bar{x}}\right) 100 \mathrm{e} \\
& \mathrm{CV}_{\mathrm{g}}(\%)=\left(\frac{\sqrt{\sigma_{P}^{2}}}{\bar{x}}\right) 100,
\end{aligned}
$$

em que:

$\sigma_{E}^{2}=$ variância do erro experimental (comum a todas as progênies), $\sigma_{P}^{2}=$ variância genética de todas as progênies e $\bar{x}=$ média geral experimental. 


\subsubsection{INTERVALOS DE CONFIANÇA ASSOCIADOS AOS PARÂMETROS GENÉTICOS}

As estimativas dos intervalos de confiança associados às variâncias genéticas de progênies, às variâncias das interações de progênies com ambientes, às variâncias fenotípicas de médias de progênies e às variâncias do erro experimental foram calculadas de acordo com as expressões sugeridas por Barbin (1993), enquanto as estimativas dos intervalos de confiança associados aos coeficientes de herdabilidade ao nível de médias de progênies foram calculadas de acordo com a expressão sugerida por Knapp et al. (1985):

- Intervalo de confiança (IC) associado à variância do erro experimental $\left(\sigma_{E}^{2}\right)$

$$
\mathrm{IC}=\mathrm{P}\left[\frac{f \sigma_{E}^{2}}{\chi_{f ; 0,975}^{2}} \leq \sigma_{E}^{2} \leq \frac{f \sigma_{E}^{2}}{\chi_{f ; 0,025}^{2}}\right]=0,95,
$$

em que:

$$
\begin{aligned}
\sigma_{E}^{2} & =\text { variância do erro experimental, } \\
\chi^{2} & =\text { qui-quadrado tabelado e }
\end{aligned}
$$

$f=$ número de graus de liberdade do erro experimental.

- Intervalo de confiança (IC) associado à variância fenotípica de médias de progênies $\left(\sigma_{\bar{F}}^{2}\right)$ :

$$
\mathrm{IC}=\mathrm{P}\left[\frac{f \sigma_{\bar{F}}^{2}}{\chi_{f ; 0,975}^{2}} \leq \sigma_{\bar{F}}^{2} \leq \frac{f \sigma_{\bar{F}}^{2}}{\chi_{f ; 0,025}^{2}}\right]=0,95,
$$

em que:

$$
\begin{aligned}
& \sigma_{\bar{F}}^{2}=\text { variância fenotípica de médias de progênies, } \\
& \chi^{2}=\text { qui-quadrado tabelado e } \\
& f=\text { número de graus de liberdade das progênies. }
\end{aligned}
$$


- Intervalo de confiança (IC) associado à variância genética de progênies $\left(\sigma_{P}^{2}\right)$ :

$$
\mathrm{IC}=\mathrm{P}\left[\frac{n t \sigma_{P}^{2}}{\chi_{n t ; 0,975}^{2}} \leq \sigma_{P}^{2} \leq \frac{n t \sigma_{P}^{2}}{\chi_{n t ; 0,025}^{2}}\right]=0,95,
$$

em que:

$$
\begin{aligned}
\sigma_{P}^{2} & =\text { variância genética de progênies } \\
\chi^{2} & =\text { qui-quadrado tabelado e } \\
n t & =\text { número de graus de liberdade associados à estimativa da variância }
\end{aligned}
$$
genética de progênies $\left(\sigma_{P}^{2}\right)$.

O valor de $n t$ foi obtido através da expressão de Satterthwaite, que é uma fórmula empregada para calcular o número de graus de liberdade associados a uma estimativa de variância obtida da combinação linear de dois quadrados médios referentes a duas fontes de variação com números de graus de liberdade conhecidos (Barbin, 1993):

$$
n t=\frac{\left(Q M_{P}-Q M_{P A}\right)^{2}}{\frac{Q M_{P}^{2}}{f_{1}}+\frac{Q M_{P A A}^{2}}{f_{2}}},
$$

em que:

$\mathrm{QM}_{\mathrm{P}}=$ quadrado médio das progênies,

$\mathrm{QM}_{\mathrm{PA}}=$ quadrado médio das interações das progênies com os ambientes,

$f_{l}=$ número de graus de liberdade das progênies e

$f_{2}=$ número de graus de liberdade das interações das progênies com os ambientes.

- Intervalo de confiança (IC) associado à variância das interações de progênies com ambientes $\left(\sigma_{P A}^{2}\right)$ :

$$
\mathrm{IC}=\mathrm{P}\left[\frac{n t \sigma_{P A}^{2}}{\chi_{n t ; 0,975}^{2}} \leq \sigma_{P A}^{2} \leq \frac{n t \sigma_{P A}^{2}}{\chi_{n t ; 0,025}^{2}}\right]=0,95,
$$


em que:

$$
\begin{aligned}
& \sigma_{P A}^{2}=\text { variância das interações de progênies com ambientes, } \\
& \chi^{2}=\text { qui-quadrado tabelado e } \\
& n t=\text { número de graus de liberdade associados à estimativa da variância das }
\end{aligned}
$$
interações de progênies com ambientes $\left(\sigma_{P A}^{2}\right)$.

$$
n t=\frac{\left(Q M_{P A}-Q M_{E}\right)^{2}}{\frac{Q M_{P A}^{2}}{f_{1}}+\frac{Q M_{E}^{2}}{f_{2}}}
$$

em que:

$\mathrm{QM}_{\mathrm{PA}}=$ quadrado médio das interações das progênies com os ambientes,

$\mathrm{QM}_{\mathrm{E}}=$ quadrado médio do erro experimental,

$f_{1}=$ número de graus de liberdade das interações das progênies com os ambientes e

$f_{2}=$ número de graus de liberdade do erro experimental.

- Intervalo de confiança (IC) associado ao coeficiente de herdabilidade ao nível de médias de progênies $\left(h_{x}^{2}\right)$ :

$\mathrm{IC}=\mathrm{P}\left\{1-\frac{1}{\left[\left(\frac{Q M_{P}}{Q M_{P A}}\right) F_{(0,975): G L_{P} ; G L_{P A}}\right]} \leq h_{x}^{2} \leq 1-\frac{1}{\left[\left(\frac{Q M_{P}}{Q M_{P A}}\right) F_{(0,025): G L_{P} ; G L_{P A}}\right]}\right]=0,95$,

em que:

$\mathrm{QM}_{\mathrm{P}}=$ quadrado médio das progênies,

$\mathrm{QM}_{\mathrm{PA}}=$ quadrado médio das interações das progênies com os ambientes,

$\mathrm{GL}_{\mathrm{P}}=$ número de graus de liberdade das progênies,

$\mathrm{GL}_{\mathrm{PA}}=$ número de graus de liberdade das interações das progênies com os ambientes e

$$
\mathrm{F}=\text { valor } \mathrm{F} \text { tabelado. }
$$




\subsubsection{TESTES DE COMPARAÇÕES DE VARIÂNCIAS E DE MÉDIAS}

Para cada caráter avaliado, a variância genética das progênies de meios irmãos com um ciclo de recombinação foi comparada com a variância genética das progênies de meios irmãos com dois ciclos de recombinação, assim como a variância

genética das progênies de irmãos germanos com um ciclo de recombinação foi comparada com a variância genética das progênies de irmãos germanos com dois ciclos de recombinação, utilizando-se o teste F (Sokal \& Rohlf, 1995):

$$
\mathrm{F}_{M I}=\frac{\sigma_{P M I 1}^{2}}{\sigma_{P M I 2}^{2}} \text {, em que } \sigma_{P M I 1}^{2}=\text { variância genética das progênies de meios }
$$

irmãos de maior magnitude e $\sigma_{P M I 2}^{2}=$ variância genética das progênies de meios irmãos de menor magnitude;

$$
\mathrm{F}_{I G}=\frac{\sigma_{P I G 1}^{2}}{\sigma_{P I G 2}^{2}} \text {, em que } \sigma_{P I G 1}^{2}=\text { variância genética das progênies de irmãos }
$$

germanos de maior magnitude e $\sigma_{P I G 2}^{2}=$ variância genética das progênies de irmãos germanos de menor magnitude.

Aos parâmetros $\sigma_{P M g 1}^{2}$ e $\sigma_{P M / 2}^{2}, \mathrm{n}_{1}$ e $\mathrm{n}_{2}$ graus de liberdade estão associados, respectivamente, assim como aos parâmetros $\sigma_{P I G 1}^{2}$ e $\sigma_{P I G 2}^{2}, \mathrm{n}_{3}$ e $\mathrm{n}_{4}$ graus de liberdade estão associados, também respectivamente, de acordo com a expressão de Satterthwaite (Barbin, 1993).

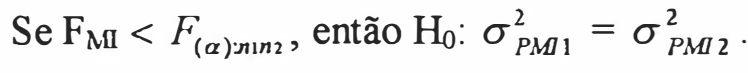

Se $\mathrm{F}_{\mathrm{MI}} \geq F_{(\alpha) \text { nn } 2}$, então $\mathrm{H}_{\mathrm{A}}: \sigma_{P M / 1}^{2} \neq \sigma_{P M / 2}^{2}$.

Se $\mathrm{F}_{\mathrm{IG}}<F_{(\alpha): n 3 n 4}$, então $\mathrm{H}_{0}: \sigma_{P I G 1}^{2}=\sigma_{P I G 2}^{2}$.

Se $\mathrm{F}_{I G} \geq F_{(\alpha): n n n 4}$, então $\mathrm{H}_{\mathrm{A}}: \sigma_{P I G 1}^{2} \neq \sigma_{P I G 2}^{2}$.

Nas expressões, tem-se que:

$\mathrm{F}_{(\alpha)}=$ valor $\mathrm{F}$ tabelado $\mathrm{e}$

$\alpha=$ nível de significância (5 e 1 \%). 
O teste empregado de comparação de médias foi o teste Tukey, calculando-se a diferença mínima significativa $(\Delta)$ (Nogueira, 1994), conforme descrita a seguir:

$$
\Delta=\frac{q_{(n ; ; n 2)} s}{\sqrt{r}},
$$

em que:

$q_{(n ; ; n 2)}=$ amplitude total estudentizada ao nível de $5 \%$,

$n_{l}=$ número total de progênies (tratamentos) da análise,

$n_{2}=$ número de graus de liberdade do erro experimental,

$\mathrm{S}=$ raiz quadrada do quadrado médio do erro experimental $\left(\mathrm{QM}_{\mathrm{E}}\right) \mathrm{e}$

$r=$ número de observações a partir das quais a média foi obtida.

As seguintes médias foram comparadas, tanto referentes às análises agrupadas por ambiente como referentes à análise conjunta agrupada:

$\begin{array}{lll}\bar{x}_{P M I 1} & v S . & \bar{x}_{P M I 2}, \\ \bar{x}_{P I G 1} & v S . & \bar{x}_{P I G 2} \mathrm{e} \\ \bar{x}_{P 1 C R} & v S . & \bar{x}_{P 2 C R} .\end{array}$

Nas expressões, tem-se que:

$x_{P M 1}$ é a média das progênies de meios irmãos com um ciclo de recombinação,

$\bar{x}_{P \text { MI } 2}$ é a média das progênies de meios irmãos com dois ciclos de recombinação,

$x_{P I G 1}$ é a média das progênies de irmãos germanos com um ciclo de recombinação,

$\bar{x}_{P I G 2}$ é a média das progênies de irmãos germanos com dois ciclos de recombinação, 
$x_{P I C R}$ é a média das progênies com um ciclo de recombinação (de ambos os tipos) e

$x_{P 2 C R}$ é a média das progênies com dois ciclos de recombinação (de ambos os tipos).

\subsubsection{ANÁLISES DE COVARIÂNCIA E CÁLCULO DAS ESTIMATIVAS DOS COEFICIENTES DE CORRELAÇÃO}

Coeficientes de correlação genética e coeficientes de correlação fenotípica de médias de progênies foram estimados para as dez combinações possíveis entre os cinco caracteres estudados, a partir da análise conjunta agrupada, para as quatro classes de progênie (meios irmãos com um ciclo de recombinação, irmãos germanos com um ciclo de recombinação, meios irmãos com dois ciclos de recombinação e irmãos germanos com dois ciclos de recombinação).

As correlações foram estimadas através das covariâncias e das variâncias. Considerando-se dois caracteres $(x$ e $y$ ), após as respectivas análises de variância conjuntas agrupadas, uma análise de variância conjunta agrupada correspondente à soma de tais caracteres $(z=x+y)$ foi realizada, incluindo também as quatro classes de progênie avaliadas. Cada análise de variância referente à soma de dois caracteres seguiu exatamente a mesma estrutura apresentada pelas análises de variância para cada caráter, individualmente, segundo a metodologia proposta por Vencovsky \& Barriga (1992). Assim, uma análise de covariância conjunta agrupada foi realizada para cada par de caracteres, cuja estrutura é semelhante à estrutura da análise de variância conjunta agrupada apresentada na Tabela 4, em que os quadrados médios (QM) são substituídos pelos produtos médios (PM) e as variâncias $\left(\sigma^{2}\right)$ são substituídas pelas covariâncias $(\mathrm{COV})$.

Os produtos médios das fontes de covariação foram, portanto, calculados da seguinte maneira: 
$\mathrm{PM}_{\mathrm{FC} \mathrm{xy}}=\left(\frac{1}{2}\right)\left(\mathrm{QM}_{\mathrm{Fvz}}-\mathrm{QM}_{\mathrm{Fv}}-\mathrm{QM}_{\mathrm{Fvy}}\right)$,

em que:

$x$ e $y$ se referem aos caracteres considerados,

$z$ se refere à soma dos dois caracteres,

$\mathrm{PM}_{\mathrm{FCxy}}$ é o produto médio da fonte de covariação considerada da soma $z \mathrm{e}$

$\mathrm{QM}_{\mathrm{Fv}}, \mathrm{QM}_{\mathrm{Fv}}$ e $\mathrm{QM}_{\mathrm{Fv}}$ são os quadrados médios da fonte de variação equivalente dos caracteres $x$ e $y$ e da soma $(z)$, respectivamente.

Assim, o produto médio das progênies $\left(\mathrm{PM}_{\mathrm{Pxy}}\right)$ e o produto médio das interações das progênies com os ambientes ( $\mathrm{PM}_{\mathrm{PAxy}}$ ) entre os caracteres $x$ e $y$ foram calculados da seguinte forma:

$$
\begin{aligned}
& \mathrm{PM}_{\mathrm{PXy}}=\left(\frac{1}{2}\right)\left(\mathrm{QM}_{\mathrm{Pz}}-\mathrm{QM}_{\mathrm{Px}}-\mathrm{QM}_{\mathrm{Py}}\right) \\
& \mathrm{PM}_{\mathrm{PAxy}}=\left(\frac{1}{2}\right)\left(\mathrm{QM}_{\mathrm{PAZ}}-\mathrm{QM}_{\mathrm{PAx}}-\mathrm{QM}_{\mathrm{PAy}}\right),
\end{aligned}
$$

em que:

$x$ e $y$ se referem aos caracteres considerados,

$z$ se refere à soma dos dois caracteres considerados,

$\mathrm{QM}_{\mathrm{PAz}}=$ quadrado médio das interações das progênies com os ambientes para a soma $z$,

$\mathrm{QM}_{\mathrm{PAx}}=$ quadrado médio das interações das progênies com os ambientes para o caráter $x$,

$\mathrm{QM}_{\mathrm{PAy}}=$ quadrado médio das interações das progênies com os ambientes para o caráter $y$,

$\mathrm{QM}_{\mathrm{Pz}_{\mathrm{Z}}}=$ quadrado médio das progênies para a soma $z$,

$\mathrm{QM}_{\mathrm{Px}_{\mathrm{x}}}=$ quadrado médio das progênies para o caráter $x \mathrm{e}$

$\mathrm{QM}_{\mathrm{Py}}=$ quadrado médio das progênies para o caráter $y$.

Em seguida, a covariância genética de progênies $\left(C O V_{P}\right.$ xy $)$ e a covariância fenotípica de médias de progênies $\left(\mathrm{COV}_{\bar{F}}\right.$ xy $)$ entre os caracteres $x$ e $y$ foram assim calculadas: 


$$
\begin{aligned}
& C O V_{P \mathrm{xy}}=\frac{1}{j k}\left(\mathrm{PM}_{\mathrm{Pxy}}-\mathrm{PM}_{\mathrm{PAxy}}\right) \mathrm{e} \\
& C O V_{\bar{F}} \mathrm{xy}=\frac{1}{j k} \mathrm{PM}_{\mathrm{Pxy} .}
\end{aligned}
$$

Os coeficientes de correlação genética $\left(r_{P \text { xy }}\right)$ e os coeficientes de correlação fenotípica de médias de progênies $\left(r_{F}\right.$ xy $)$ entre os caracteres $x$ e $y$ foram, portanto, assim estimados:

$$
\begin{aligned}
& r_{P \mathrm{xy}}=\frac{C O V_{P_{x y}}}{\sqrt{\sigma_{P x}^{2} \sigma_{P y}^{2}}} \mathrm{e} \\
& r_{\bar{F}} \mathrm{xy}=\frac{C O V_{\bar{F} x y}}{\sqrt{\sigma_{\bar{F} x}^{2}}} \frac{\sigma_{\bar{F} y}^{2}}{\sigma_{\bar{F}}^{2}}
\end{aligned}
$$

em que:

$$
\begin{aligned}
& \sigma_{P x}^{2}=\text { variância genética de progênies para o caráter } x, \\
& \sigma_{P y}^{2}=\text { variância genética de progênies para o caráter } y, \\
& \sigma_{\bar{F} x}^{2}=\text { variância fenotípica de médias de progênies para o caráter } x \mathrm{e} \\
& \sigma_{\bar{F} y}^{2}=\text { variância fenotípica de médias de progênies para o caráter } y .
\end{aligned}
$$

\subsubsection{INTERVALOS DE CONFIANÇA ASSOCIADOS ÀS CORRELAÇÕES E TESTES DE SIGNIFICÂNCIA}

Os intervalos de confiança associados aos coeficientes de correlação genética e aos coeficientes de correlação fenotípica de médias de progênies foram obtidos através da metodologia proposta por Snedecor \& Cochran (1967) e Zar (1984). Os coeficientes de correlação genética e de correlação fenotípica de médias de progênies foram convertidos para a variável $z$, através da seguinte fórmula:

$$
\mathrm{z}=\frac{1}{2}[\ln (1+r)-\ln (1-r)], \text { em que } \ln \text { significa o logaritmo neperiano. }
$$


A variável $z$ está, por sua vez, associada ao parâmetro $\sigma$, obtido pela expressão seguinte:

$$
\sigma_{z}=\frac{1}{\sqrt{n-3}} \text {, em que } n \text { corresponde ao número de pares de observações }
$$

Para a variável $z$, há um intervalo de confiança, assim designado:

$z-\left(z_{0,05} \sigma_{z}\right) \leq z \leq z+\left(z_{0,05} \sigma_{z}\right)$, em que $z_{0,05}=1,96$, para $P$ equivalente a 95 $\%$.

Em seguida, ransforma-se o intervalo de confiança encontrado para a variável $z$ em um intervalo de confiança coerente para o coeficiente de correlação genética e para o coeficiente de correlação fenotípica de médias de progênies, aplicando-se a fórmula de conversão de $z$ para $r$, assim expressa:

$$
\mathrm{r}=\frac{\left(e^{2 z}-1\right)}{\left(e^{2 z}+1\right)}, \text { em que } e \text { representa o algarismo neperiano. }
$$

O limite inferior e o limite superior dos intervalos de confiança, expressos em função de $z$, foram, portanto, convertidos em valores equivalentes para os coeficientes de correlação genética e para os coeficientes de correlação fenotípica de médias de progênies, obtendo-se os respectivos intervalos de confiança para as referidas estimativas.

Para os coeficientes de correlação genética e de correlação fenotípica de médias de progênies, testes de significância foram também efetuados com a finalidade de investigar se as estimativas obtidas diferem ou não estatisticamente de zero. A metodologia empregada foi proposta por Vencovsky \& Barriga (1992).

Para a correlação fenotípica de médias de progênies, a significância dos coeficientes foi verificada diretamente em tabela apropriada - Significant values of $r$ and $R$ (Steel \& Torrie, 1980) -, com $(n-2)$ graus de liberdade, em que $n$ representa o conjunto de pares de dados (100). 
Para a correlação genética, a significância dos coeficientes não pôde ser observada diretamente a partir da consulta de uma tabela, mas por intermédio das etapas que se seguem (Vencovsky \& Barriga, 1992). Primeiro, calcula-se a variância do coeficiente, através da fórmula abaixo:

$$
\begin{aligned}
& \operatorname{var}\left(r_{P}\right)=\frac{1}{g_{1} j^{2} t_{1} t_{2}}\left[1+(j-1) t_{1}\right]\left[1+(j-2) t_{2}+r_{f}^{2}\right]+ \\
& +\frac{1}{g_{2} j^{2} t_{1} t_{2}}\left[\left(1-t_{1}\right)\left(1-t_{2}\right)+r_{f}^{2}\right],
\end{aligned}
$$

em que:

$g_{1}$ e $g_{2}$ correspondem ao número de graus de liberdade relativos às progênies e ao erro experimental, respectivamente,

$j$ corresponde ao número de repetições dos ensaios,

$$
\begin{aligned}
& t_{1}=\frac{\sigma_{P x}^{2}}{\sigma_{P x}^{2}+\sigma_{E x}^{2}}, \\
& t_{2}=\frac{\sigma_{P y}^{2}}{\sigma_{P y}^{2}+\sigma_{E y}^{2}} \mathrm{e} \\
& r_{f}=\frac{C O V_{P x y}+C O V_{E x y}}{\sqrt{\left[\left(\sigma_{P x}^{2}+\sigma_{E x}^{2}\right)\left(\sigma_{P y}^{2}+\sigma_{E y}^{2}\right)\right]}},
\end{aligned}
$$

em que:

$C O V_{P x y}=$ covariância genética de progênies entre os caracteres $x$ e $y$,

$C O V_{E x y}=$ covariância do erro experimental entre os caracteres $x$ e $y$,

$\sigma_{P x}^{2}=$ variância genética do caráter $x$,

$\sigma_{E x}^{2}=$ variância do erro experimental do caráter $x$,

$\sigma_{P y}^{2}=$ variância genética do caráter $y$ e

$\sigma_{E y}^{2}=$ variância do erro experimental do caráter $y$.

Em seguida, obtém-se a expressão correspondente ao teste $t$ : 


$$
\mathrm{t}=\frac{r_{P}}{\sqrt{\operatorname{var}\left(r_{P}\right)}} \text {, com aproximadamente }(n-2) \text { graus de liberdade, em que } n
$$

representa o número de progênies avaliadas (100). 


\section{RESULTADOS E DISCUSSÃO}

\subsection{ANÁLISE GERAL DOS DADOS}

Os resultados do presente trabalho foram obtidos a partir de quatro experimentos no delineamento em látice $10 \times 10$, avaliados em três ambientes e com duas repetições por ambiente. Os ambientes nos quais os experimentos foram instalados foram as áreas experimentais Fazenda Caterpillar (anos agrícolas de 1992/93 e 1993/94, ambientes 1 e 3, respectivamente) e Fazenda Areião (ano agrícola de 1992/93, ambiente 2), ambas pertencentes ao município de Piracicaba - SP.

As médias experimentais para os caracteres peso de espigas, altura da planta, altura da espiga, posição relativa da espiga e índice de espigas, referentes às análises agrupadas, para cada ambiente, compreendem a média geral, as médias das progênies de meios irmãos e de irmãos germanos com um e com dois ciclos de recombinação, as médias de todas as progênies de meios irmãos e de irmãos germanos e as médias de todas as progênies do primeiro e do segundo ciclo. Para o peso de espigas, os maiores valores verificados são aqueles do ambiente 3, cuja média geral é igual a 160,87 g/planta, seguidos por aqueles do ambiente 1, cuja média geral é igual a 156,40 g/planta. Os menores valores verificados foram aqueles provenientes do ambiente 2 , cuja média geral eqüivale a 137,52 g/planta. As três médias gerais correspondem a 8,04, 7,82 e 6,88 toneladas/ha, respectivamente. Para os caracteres altura da planta, altura da espiga e posição relativa da espiga, o ambiente 3 também apresentou as mais altas estimativas, seguido em ordem decrescente pelos ambientes 1 e 2 . Para a altura da planta, os valores

encontrados para a média geral, nos três ambientes, foram, respectivamente, 232,51, 227,19 e $211,73 \mathrm{~cm} /$ planta. Para a altura da espiga, 132,43, 123,97 e 105,98 cm/planta. 
Para a posição relativa da espiga, 0,57, 0,55 e 0,50. Para o índice de espigas, ao contrário dos demais caracteres, os valores do ambiente 1 superaram os valores dos outros dois ambientes. Os valores obtidos para a média geral, nos ambientes 1, 3 e 2, foram, respectivamente, 1,10, 1,05 e 1,04 espigas/planta (Tabelas 5, 6, 7, 8 e 9).

As médias experimentais para os caracteres peso de espigas, altura da planta, altura da espiga, posição relativa da espiga e indice de espigas, referentes à análise conjunta agrupada, compreendem também a média geral, as médias das progênies de meios irmãos e de irmãos germanos com um e com dois ciclos de recombinação, as médias de todas as progênies de meios irmãos e de irmãos germanos e as médias de todas as progênies do primeiro e do segundo ciclo. As estimativas encontradas para a média geral foram $151,60 \mathrm{~g} /$ planta, $223,81 \mathrm{~cm} /$ planta, $120,79 \mathrm{~cm} /$ planta, 0,54 e 1,07 espigas/planta, para os caracteres peso de espigas, altura da planta, altura da espiga, posição relativa da espiga e índice de espigas, respectivamente. Para o peso de espigas, a estimativa de $151,60 \mathrm{~g} /$ planta corresponde a uma produção de aproximadamente 7,58 toneladas/ha, superando a produção da testemunha utilizada nos experimentos $(128,28$ g/planta ou 6,41 toneladas/ha). Os valores estimados para a altura da planta e a altura da espiga, $223,81 \mathrm{~cm} /$ planta e $120,79 \mathrm{~cm} /$ planta, também foram superiores àqueles obtidos para a testemunha, $204,96 \mathrm{~cm} /$ planta e $107,36 \mathrm{~cm} /$ planta, respectivamente. Os valores encontrados para a posição relativa da espiga e o índice de espigas foram equivalentes aos obtidos para a testemunha, 0,52 e 1,06 espigas/planta, respectivamente (Tabela 20).

Os valores encontrados para o coeficiente de variação experimental, referentes às análises agrupadas, para cada ambiente, foram 11,16, 15,51 e 20,88 \%, para o peso de espigas, 5,56,6,21 e 6,77\%, para a altura da planta, 5,85, 8,59 e 9,12\%, para a altura da espiga, 3,53,5,47 e 5,74 \%, para a posição relativa da espiga, e 13,15, 15,45 e 20,23 \%, para o índice de espigas. Para o peso de espigas e o índice de espigas, as estimativas correspondem aos ambientes 1, 3 e 2, respectivamente. Para a altura da planta, a altura da espiga e a posição relativa da espiga, as estimativas se referem aos ambientes 1,2 e 3, respectivamente. Para a análise conjunta agrupada, os valores foram $15,94 \%, 6,22 \%, 8,02 \%, 5,01 \%$ e $16,42 \%$, para o peso de espigas, a altura da planta, a altura da espiga, a posição relativa da espiga e o índice de espigas, respectivamente. 
Valores semelhantes aos obtidos são relatados por Terasawa Júnior (1993), Arias (1995), Takeda (1997) e Rezende (1997), em experimentos de avaliação de progênies. Pode-se considerar, portanto, que as estimativas verificadas coincidem com aquelas estimativas normalmente obtidas, concluindo, assim, que a qualidade dos experimentos realizados está dentro dos padrões aceitáveis na experimentação agronômica (Tabelas $10,11,12,13,14$ e 21$)$.

O teste de homocedasticidade dos quadrados médios foi aplicado para avaliar, para cada experimento, a possibilidade de reunião dos três ambientes em estudo e, consequentemente, avaliar a possibilidade de realização das análises de variância conjuntas. Observa-se, assim, que o único quociente entre o maior e o menor quadrado médio do erro experimental superior a 7 é verificado para a posição relativa da espiga, no experimento 1 , mesmo assim apenas levemente superior (aproximadamente 7,49 ). Para os demais caracteres, em nenhum dos experimentos o quociente foi superior a 7. As análises conjuntas foram, portanto, normalmente realizadas, reunindo-se os três ambientes considerados.

Para o peso de espigas, as análises de variância agrupadas por ambiente revelaram que os quadrados médios para todo o conjunto das progênies e para cada uma das quatro classes foram significativos $(\mathrm{P} \leq 1 \%)$, com exceção daquele referente às progênies de meios irmãos 1 , não significativo, e daquele referente às progênies de meios irmãos 2 , significativo porém a outro nível de significância $(\mathrm{P} \leq 5 \%)$, ambos no ambiente 2 , indicando assim a existência de suficiente variabilidade genética tanto para todas as progênies como dentro de cada uma das quatro classes e, consequentemente, a possibilidade de seleção de progênies superiores (excetuando apenas, evidentemente, as progênies de meios irmãos 1 do ambiente 2). Os quadrados médios dos grupos foram significativos nos ambientes 1 e 3 ( $\mathrm{P} \leq 1 \%$ ), bem como os quadrados médios das recombinações $(\mathrm{P} \leq 1 \%$ ), tornando necessário, assim, o teste de comparação de médias para dirimir as eventuais dúvidas (Tabela 10). A análise conjunta agrupada da variância mostrou que as diferenças entre os ambientes foram significativas $(\mathrm{P} \leq 1 \%$ ), como também significativos foram os efeitos de todo o conjunto das progênies e das quatro classes $(\mathrm{P} \leq 1 \%)$, indicando, portanto, a existência de suficiente variabilidade genética. 
A seleção de progênies com médias superiores seria, assim, plenamente possível, tanto em todo o conjunto das progênies como em cada uma das classes. Os quadrados médios para as recombinações e para a interação entre os tipos e as recombinações foram significativos ( $\mathrm{P} \leq 1 \%$ e $\mathrm{P} \leq 5 \%$, respectivamente), indicando, portanto, a necessidade de realização dos testes de comparação de médias. Em relação às interações com os ambientes, os quadrados médios para todo o conjunto das progênies, para as progênies de irmãos germanos 1 e para os tipos foram significativos $(\mathrm{P} \leq 5 \%)$. O coeficiente de variação genética foi igual a 7,60 \% (Tabela 21 ).

Para a altura da planta, as análises de variância agrupadas por ambiente revelaram que os quadrados médios de todo o conjunto das progênies, das progênies de irmãos germanos 1 e também das progênies de irmãos germanos 2 foram significativos ( $\mathrm{P} \leq 1 \%$ ) nos ambientes 1 e 2 , enquanto, no ambiente 3 , apenas o quadrado médio das progênies de meios irmãos 2 revelou-se significativo $(\mathrm{P} \leq 1 \%)$. Nos três ambientes, o efeito das recombinações foi significativo ( $P \leq 5 \%$ ), enquanto que, no ambiente 3 , houve ainda significância ( $\mathrm{P} \leq 1 \%$ ) para a interação entre os tipos e as recombinações $\mathrm{e}$ para os grupos. Os testes de comparação de médias são, portanto, requeridos para apontar as possíveis alterações (Tabela 11). A análise conjunta agrupada da variância mostrou que os quadrados médios para os ambientes, para todo o conjunto das progênies e para cada uma das quatro classes foram significativos ( $\mathrm{P} \leq 1 \%$ ), com exceção apenas do quadrado médio para as progênies de meios irmãos 1 , também significativo, porém a outro nível $(\mathrm{P} \leq 5 \%)$. As diferenças entre os ambientes foram, portanto, significativas. A significância dos quadrados médios para cada classe de progênie revela a existência de variabilidade genética disponível e, por conseguinte, a possibilidade de seleção de progênies superiores. Os efeitos das recombinações e da interação entre os tipos e as recombinações foram significativos ( $\mathrm{P} \leq 5 \%$ ), havendo a necessidade de efetuar os testes de comparação de médias para apontar as possíveis alterações. As interações dos ambientes com as progênies foram não significativas, mas significativas com as recombinações e também com os grupos $(\mathrm{P} \leq 1 \%$ e $\mathrm{P} \leq 5 \%$, respectivamente). O coeficiente de variação genética foi igual a 2,59 \% (Tabela 21). 
Para a altura da espiga, as análises de variância agrupadas por ambiente revelaram que, no ambiente 1 , os quadrados médios para todo o conjunto das progênies e para cada uma das quatro classes foram significativos ( $\mathrm{P} \leq 1 \%$ ), com exceção do quadrado médio para as progênies de meios irmãos 2 , também significativo, porém a outro nível $(\mathrm{P} \leq 5 \%)$. No ambiente 2 , os quadrados médios para todo o conjunto das progênies e para as progênies de irmãos germanos 1 , de meios irmãos 2 e de irmãos germanos 2 foram significativos ( $\mathrm{P} \leq 1 \%$ ), enquanto o quadrado médio para as progênies de meios irmãos 1 não expressou nenhuma significância. No ambiente 3 , considerando-se as progênies, apenas aquelas de meios irmãos 1 apresentaram quadrado médio significativo $(\mathrm{P} \leq 1 \%$ ), constituindo-se a única classe dentro da qual a seleção seria possível, uma vez que as demais não revelaram variabilidade genética. Para os três ambientes, os quadrados médios para os grupos e para as recombinações foram significativos $(\mathrm{P} \leq 1 \%)$, exceção apenas para o quadrado médio das recombinações no ambiente 3, também significativo, porém a outro nível ( $\mathrm{P} \leq 5 \%$ ). Constatou-se ainda significância ( $\mathrm{P} \leq 1 \%$ ), nos ambientes 2 e 3, para a interação entre os tipos e as recombinações. Os testes de comparação de médias são requeridos, assim, para verificar quais alterações ocorreram (Tabela 12). A análise conjunta agrupada da variância indicou que os quadrados médios para os ambientes, para todo o conjunto das progênies e para as quatro classes foram significativos $(\mathrm{P} \leq 1 \%$ ), revelando a existência de diferenças entre os ambientes e a presença de variabilidade genética disponível. Em decorrência, assim, da disponibilidade de variabilidade genética tanto em todo o conjunto das progênies como em cada uma das quatro classes, o procedimento de seleção de progênies com médias superiores é viável. Os quadrados médios para os grupos, para as recombinações e para a interação entre os tipos e as recombinações foram também significativos ( $\mathrm{P} \leq 1 \%$ ), implicando, assim, a necessidade de efetuar os testes de comparação de médias. O conjunto de todas as progênies e as progênies de meios irmãos 1 interagiram significativamente ( $\mathrm{P} \leq 5 \%$ ) com os ambientes, enquanto, para as progênies de irmãos germanos 1 , de meios irmãos 2 e de irmãos germanos 2 , os quadrados médios não revelaram nenhuma interação significativa com os ambientes. 
Constatou-se também que houve uma interação significativa dos ambientes com os grupos ( $\mathrm{P} \leq 5 \%)$ e que houve uma interação significativa dos ambientes com a interação entre os tipos $\mathrm{e}$ as recombinações $(\mathrm{P} \leq 1 \%$ ). $\mathrm{O}$ coeficiente de variação genética foi igual a $3,40 \%$ (Tabela 21 ).

Para a posição relativa da espiga, as análises de variância agrupadas por ambiente revelaram que, no ambiente 1 , os quadrados médios para todo o conjunto das progênies, para as progênies de meios irmãos 1, para as progênies de irmãos germanos 1 e para as progênies de irmãos germanos 2 acusaram significância ( $\mathrm{P} \leq 1 \%$ ), indicando, assim, variabilidade genética suficiente e, portanto, a possibilidade de praticar seleção. $\mathrm{Na}$ classe das progênies de meios irmãos 2 , nenhuma variabilidade genética significativa foi detectada. No ambiente 2 , os quadrados médios para todo o conjunto das progênies e para as progênies de irmãos germanos 2 foram significativos $(P \leq 1 \%)$, enquanto o quadrado médio para as progênies de irmãos germanos 1 foi significativo a outro nível $(\mathrm{P} \leq 5 \%)$. Os quadrados médios para as progênies de meios irmãos 1 e para as progênies de meios irmãos 2 não se revelaram significativos. No ambiente 3 , considerando-se as progênies, apenas as de meios irmãos 1 apresentaram o quadrado médio significativo $(\mathrm{P} \leq 5 \%$ ). $\mathrm{O}$ efeito das recombinações foi significativo nos três ambientes ( $\mathrm{P} \leq 5 \%$, no ambiente 1 , e $\mathrm{P} \leq 1 \%$, nos ambientes 2 e 3 ). As recombinações apresentaram ainda uma significativa interação com os tipos $(\mathrm{P} \leq 1 \%)$ no ambiente 2 . $\mathrm{O}$ efeito dos grupos foi significativo apenas nos ambientes 2 e 3 ( $\mathrm{P} \leq 1 \%$ e $\mathrm{P} \leq 5 \%$, respectivamente). O teste de comparação de médias deve ser, assim, realizado (Tabela 13). A análise conjunta agrupada da variância indicou que os quadrados médios para os ambientes, para o conjunto de todas as progênies e para as progênies de meios irmãos 1 foram significativos $(\mathrm{P} \leq 1 \%$ ), enquanto que as demais classes não apresentaram variabilidade genética significativa. As diferenças entre os ambientes dos experimentos são, pois, significativas. $\mathrm{O}$ efeito das recombinações revelou-se significativo $(\mathrm{P} \leq 1 \%)$, como também significativa $(\mathrm{P} \leq 1 \%)$ foi a interação entre os tipos e as recombinações. $\mathrm{O}$ efeito dos grupos apresentou-se também significativo, porém a outro nível $(\mathrm{P} \leq 5 \%)$. O teste de comparação de médias é necessário para detectar as possíveis alterações. 
Houve interação significativa dos ambientes com todo o conjunto das progênies, com as progênies de irmãos germanos 1 e com as progênies de irmãos germanos $2(\mathrm{P} \leq 5 \%)$. A interação dos ambientes foi também significativa com os grupos $(\mathrm{P} \leq 1 \%)$, com as recombinações ( $\mathrm{P} \leq 5 \%$ ) e com a interação entre os tipos e as recombinações ( $\mathrm{P} \leq 1 \%$ ). O coeficiente de variação genética foi igual a 1,36 \% (Tabela 21).

Para o índice de espigas, as análises de variância agrupadas por ambiente revelaram que, no ambiente 1 , os quadrados médios para todo o conjunto das progênies, para as progênies de meios irmãos 1 e para as progênies de meios irmãos 2 não acusaram significância, contudo os quadrados médios para as progênies de irmãos germanos 1 e para as progênies de irmãos germanos 2 foram significativos $(P \leq 5 \%)$. No ambiente 2, considerando-se as progênies, somente aquelas de irmãos germanos 1 revelaram significância $(\mathrm{P} \leq 1 \%$ ). As demais classes não demonstraram variabilidade genética. Nos ambientes 1 e 2, todas as demais fontes de variação (grupos, tipos, recombinações e tipos $\mathrm{x}$ recombinações) não expressaram nenhuma significância, dispensando, assim, os testes de comparação de médias, os quais, em tais ambientes, não são imprescindíveis. No ambiente 3 , os quadrados médios para o conjunto de todas as progênies ( $\mathrm{P} \leq 1 \%$ ), para as progênies de irmãos germanos 1 ( $\mathrm{P} \leq 1 \%$ ), para as progênies de meios irmãos $2(\mathrm{P} \leq 5 \%)$ e também para as progênies de irmãos germanos $2(\mathrm{P} \leq 1 \%)$ foram significativos. Os efeitos das recombinações e dos grupos também foram significativos ( $\mathrm{P} \leq 5 \%$ e $\mathrm{P} \leq 1 \%$, respectivamente), demandando a realização dos testes de comparação de médias para averiguar as possiveis alterações (Tabela 14). A análise conjunta agrupada da variância indicou que os quadrados médios para o conjunto de todas as progênies, para as progênies de meios irmãos 1 e também para as progênies de irmãos germanos 2 foram significativos ( $\mathrm{P} \leq 5 \%, \mathrm{P} \leq 5 \%$ e $\mathrm{P} \leq 1 \%$, respectivamente). As progênies de meios irmãos $2 \mathrm{e}$ as progênies de irmãos germanos 1 não apresentaram variabilidade genética, tornando inócuo qualquer processo de seleção, já que as progênies não diferiram estatisticamente. $O$ efeito dos ambientes não foi significativo, logo não há diferenças ambientais. Os grupos, os tipos, as recombinações e a interação entre os tipos e as recombinações também não revelaram significância. 
Dispensa-se até mesmo, portanto, o teste de comparação de médias, o qual perde a obrigatoriedade e torna-se opcional. Houve interação significativa dos ambientes com todo o conjunto das progênies, com as progênies de irmãos germanos 1 , com as progênies de meios irmãos 2 , com os grupos e com os tipos ( $\mathrm{P} \leq 1 \%$ ). O coeficiente de variação genética foi igual a 3,34\% (Tabela 21).

\subsection{ANÁLISES ESTATÍSTICO-GENÉTICAS}

As análises estatísticas possibilitam a obtenção dos componentes de variância, os quais expressam a magnitude da variabilidade genética de uma população, bem como da interação dos genótipos com os ambientes, ambas de fundamental importância para o melhoramento genético das plantas. Os caracteres foram analisados separadamente, visando assim estudar os efeitos de um ciclo adicional de recombinação para a seleção recorrente.

\subsubsection{PESO DE ESPIGAS}

Para o peso de espigas, todos os testes Tukey efetuados entre as diversas médias obtidas, nos três ambientes, foram não significativos. Assim, os contrastes efetuados entre as progênies das duas recombinações (progênies do $1^{\circ}$ ciclo x progênies do $2^{\underline{o}}$ ciclo, considerando-se os dois tipos - meios irmãos e irmãos germanos - tanto separadamente como juntos) foram estatisticamente não significativos, contrariando os resultados fornecidos pelas análises agrupadas da variância dos ambientes 1 e 3 , através dos quadrados médios das recombinações, que haviam expressado significância, mas confirmando o quadrado médio das recombinações da análise agrupada da variância do ambiente 2, o qual não havia apresentado significância (Tabela 10). Um ciclo adicional de recombinação não foi, portanto, suficiente para alterar nem a média das progênies de meios irmãos nem a média das progênies de irmãos germanos nos três ambientes em estudo (Tabela 15). 
Para a análise conjunta agrupada, todos os testes Tukey efetuados entre as diversas médias obtidas foram também estatisticamente não significativos. Os contrastes efetuados entre as progênies das duas recombinações (progênies do $1^{0}$ ciclo x progênies do $2^{0}$ ciclo, considerando-se as progênies de meios irmãos e as progênies de irmãos germanos tanto separadamente como juntas) não indicaram, assim, significância alguma. Embora o quadrado médio das recombinações (Tabela 21) tenha sido significativo, os testes de comparação de médias indicaram que nenhuma alteração ocorreu, concluindo-se, portanto, que um ciclo adicional de recombinação não produziu nenhuma alteração estatisticamente significativa nas médias das progênies de meios irmãos e de irmãos germanos (Tabela 22).

As estimativas da variância genética de progênies, da variância das interações de progênies com ambientes, da variância fenotípica de médias de progênies, todas em ( $\mathrm{g} / \mathrm{planta})^{2}$, da herdabilidade ao nivel de médias de progênies, em porcentagem, e da resposta esperada à seleção entre progênies (tanto em valor absoluto, em g/planta, como em porcentagem da média) foram obtidas para cada uma das quatro classes de progênie. A estimativa da variância do erro experimental, também em $(\mathrm{g} / \mathrm{planta})^{2}$, comum às quatro classes, também foi obtida. Todas as estimativas, com os respectivos intervalos de confiança (com exceção daquelas da resposta esperada à seleção), encontram-se na Tabela 23.

A estimativa da variância genética das progênies de meios irmãos 1 foi de $123,40$ (g/planta) $)^{2}$, próxima de valores obtidos por Lima Neto (1994) e Takeda (1997). A estimativa da variância genética das progênies de meios irmãos $2,81,48$ ( $\mathrm{g} / \mathrm{planta})^{2}$, sofreu, portanto, um decréscimo em relação àquela encontrada no ciclo anterior, 123,40 $(\mathrm{g} / \text { planta })^{2}$. Valores próximos à estimativa da segunda recombinação foram relatados por Geraldi et al. (1985), Tosello et al. (1987) e Lima Neto (1994). Ambas as estimativas foram, entretanto, superiores aos valores relatados, na literatura, por Souza Júnior (1983), Santos \& Naspolini Filho (1986a), Santos \& Naspolini Filho (1986b), Souza Júnior \& Miranda Filho (1989), Santos \& Miranda Filho (1992) e Souza Júnior et al. (1993). 
A estimativa da variância genética das progênies de irmãos germanos 1 foi de $167,68(\mathrm{~g} / \text { planta })^{2}$, enquanto a estimativa da variância genética das progênies de irmãos germanos 2 foi de 155,53 (g/planta) ${ }^{2}$. Tais estimativas foram similares a alguns valores relatados por Valois (1982) e por Araújo (1992), porém inferiores a outras estimativas relatadas por Valois (1982) e por Araújo (1992), bem como por Nass (1992) e por Lima Neto (1994), e superiores a estimativas relatadas por Farias Neto (1995) e por Rezende (1997).

A variância das interações de progênies com ambientes foi negativa para as progênies de meios irmãos $1,-5,32$ (g/planta $)^{2}$, o que é um indício de que o parâmetro deve ser estatisticamente nulo, porém positiva para as progênies de meios irmãos 2 , 43,03 (g/planta) $)^{2}$. Para as progênies de irmãos germanos, o parâmetro apresentou um decréscimo, do $1^{\circ}$ para o $2^{\circ}$ ciclo de recombinação, de 67,28 (g/planta) ${ }^{2}$ para 45,77 (g/planta $)^{2}$. A variância fenotípica de médias de progênies oscilou de 218,95 (g/planta ${ }^{2}$ para $193,14(\mathrm{~g} / \text { planta })^{2}$ e de $287,43(\mathrm{~g} / \text { planta })^{2}$ para $268,10(\mathrm{~g} / \text { planta })^{2}$, do $1^{\circ}$ para o $2^{\circ}$ ciclo de recombinação, considerando-se as progênies de meios irmãos e as progênies de irmãos germanos, respectivamente.

A herdabilidade ao nível de médias de progênies foi equivalente a $56,36 \%$, para as progênies de meios irmãos 1, valor semelhante a estimativas obtidas por Aguilar Moran (1984), Santos (1985), Soares Filho (1987), Arias (1995), Camargo Buitrago (1996) e Takeda (1997). O valor verificado para as progênies de meios irmãos 2 foi inferior, 42,19\%, aproximando-se das estimativas relatadas por Santos (1985), Bigoto (1988) e Pellicano (1990). Os valores encontrados para as progênies de irmãos germanos 1 e de irmãos germanos 2 foram de $58,34 \%$ e $58,01 \%$, respectivamente, próximos daqueles obtidos por Valois (1982) e por Lima Neto (1994).

A resposta esperada à seleção entre progênies decresceu de 14,59 g/planta para $10,26 \mathrm{~g} /$ planta, das progênies de meios irmãos 1 para as progênies de meios irmãos 2 , ou de 9,54\% para 6,80 \%, em percentual da média. Para as progênies de irmãos germanos 1 e de irmãos germanos 2, as respostas esperadas foram 17,31 g/planta e $16,62 \mathrm{~g} /$ planta ou, em percentual da média, $11,19 \%$ e $11,24 \%$, respectivamente. As estimativas foram, pois, praticamente as mesmas do $1^{\circ}$ para o $2^{\circ}$ ciclo de recombinação. 
Os valores, em percentual da média, são superiores nas progênies de irmãos germanos em comparação com aqueles verificados nas progênies de meios irmãos, pois incluem, além de uma maior quantidade da variância genética aditiva, também uma porcentagem da variância genética dominante, a qual, na seleção recorrente, não é aproveitada. Lima Neto (1994) registrou respostas esperadas à seleção entre progênies de irmãos germanos, empregando a mesma intensidade de seleção (10\%), ainda mais elevadas. As respostas esperadas são relativamente altas, porque a seleção seria truncada para somente um caráter, o que não acontece comumente na prática, já que o processo seletivo envolve geralmente vários caracteres, simultaneamente. As respostas esperadas tanto entre as progênies de meios irmãos como entre as progênies de irmãos germanos, em percentual da média, podem ser consideradas altas quando comparadas com algumas estimativas obtidas, na literatura, por Paterniani \& Vencovsky (1977), Hallauer (1984), Moll \& Hanson (1984), Stromberg \& Compton (1989), Moll (1991) e Lamkey (1992). As respostas esperadas entre as progênies de meios irmãos 1 e entre as progênies de meios irmãos 2 são similares à estimativa relatada por Landi \& Frascaroli (1993).

Os testes $\mathrm{F}$ para comparação da variância genética das progênies de meios irmãos do primeiro ciclo de recombinação com a variância genética das progênies de meios irmãos do segundo ciclo de recombinação e para comparação da variância genética das progênies de irmãos germanos do primeiro ciclo de recombinação com a variância genética das progênies de irmãos germanos do segundo ciclo de recombinação encontram-se na Tabela 28 . Verifica-se que, do $1^{\circ}$ para o $2^{\circ}$ ciclo, houve um decréscimo tanto na variância genética das progênies de meios irmãos como na variância genética das progênies de irmãos germanos - de 123,40 para 81,48 (g/planta) ${ }^{2}$, nas progênies de meios irmãos, e de 167,68 para 155,53 (g/planta) ${ }^{2}$, nas progênies de irmãos germanos -, porém estatisticamente não significativo, já que os valores calculados do teste $F$ foram inferiores àqueles tabelados. Assim, conclui-se que um ciclo adicional de recombinação não foi suficiente nem para elevar a média (Tabelas 15 e 22) nem para elevar a variabilidade genética do caráter peso de espigas. Observa-se, ainda, que também não houve nenhum aumento significativo nem no coeficiente de herdabilidade ao nível de médias de progênies e nem na resposta esperada à seleção (Tabela 23). 
Analisando os resultados experimentais relatados na literatura, tanto em uma espécie autógama, como a soja (Piper \& Fehr, 1987; Guimarães \& Fehr, 1989), como no próprio milho, uma espécie alógama (Covarrubias-Prieto et al., 1989; Han \& Hallauer, 1989; Lamkey et al., 1995), pode-se inferir que os resultados obtidos no presente trabalho não modificam o panorama geral a respeito da eficiência da estratégia proposta, ou seja, da efetividade de um ciclo adicional de recombinação precedendo o processo seletivo. Os trabalhos mencionados na literatura também não recomendam a realização de intercruzamentos entre as plantas visando elevar a média ou incrementar a variabilidade genética de uma população.

\subsubsection{Altura da PLANTA, ALTURA DA ESPIGA E RELAÇÃO AE/AP}

Os caracteres altura da planta, altura da espiga e posição relativa da espiga (relação $\mathrm{AE} / \mathrm{AP}$ ) são caracteres altamente correlacionados e apresentam elevados valores para o coeficiente de herdabilidade, assim serão abordados e discutidos em conjunto neste trabalho.

Para a altura da planta e a altura da espiga, todos os testes Tukey efetuados entre as diversas médias obtidas, nos três ambientes, foram também não significativos. Da mesma maneira, os contrastes observados entre as progênies da $1^{\underline{a}}$ recombinação e as progênies da $2^{a}$ recombinação, considerando-se, analogamente, os dois tipos (meios irmãos e irmãos germanos) tanto separadamente como juntos, também não acusaram significância, confrontando-se com a hipótese previamente formulada a partir dos quadrados médios das recombinações, que haviam expressado significância, fornecidos pelas análises agrupadas da variância dos três ambientes considerados (Tabelas 11 e 12, respectivamente). Os testes de comparação de médias permitem, portanto, rejeitar a hipótese de ocorrência de alguma alteração, nas médias das progênies de meios irmãos e de irmãos germanos, provocada por um ciclo adicional de recombinação, para a altura da planta e a altura da espiga (Tabelas 16 e 17, respectivamente), nos três ambientes considerados. 
Para a posição relativa da espiga, todos os testes Tukey efetuados entre as diversas médias obtidas foram não significativos, com exceção apenas do contraste verificado entre as progênies de meios irmãos 1 e as progênies de meios irmãos 2 , no ambiente 2, o qual foi significativo. Observando-se as Tabelas 8 e 18, constata-se que houve realmente uma redução superior à diferença mínima significativa na média das progênies de meios irmãos com um ciclo adicional de recombinação. Conclui-se, portanto, após a realização do teste de comparação das duas médias, que a hipótese previamente formulada, em virtude da significância do quadrado médio das recombinações, fornecido pela análise agrupada da variância do ambiente 2 (Tabela 13), deve ser aceita. Assim, pode-se inferir que um ciclo adicional de recombinação gerou um decréscimo na média das progênies de meios irmãos, no ambiente 2. No entanto, nos ambientes 1 e 3, os testes de comparação de médias não confirmaram a hipótese suscitada pelos quadrados médios das recombinações fornecidos pelas análises agrupadas da variância (Tabela 13), já que os contrastes entre as progênies das duas recombinações não foram estatisticamente significativos. Nos ambientes 1 e 3 , portanto, um ciclo adicional de recombinação não propiciou mudanças nem na média das progênies de meios irmãos nem na média das progênies de irmãos germanos (Tabela 18).

Para a análise conjunta agrupada, todos os testes Tukey efetuados entre as diversas médias obtidas foram estatisticamente não significativos, para os três caracteres avaliados. Todos os contrastes observados entre as progênies das duas recombinações (progênies do $1^{\circ}$ ciclo $\times$ progênies do $2^{0}$ ciclo, considerando-se, de maneira análoga, as progênies de meios irmãos e as progênies de irmãos germanos tanto separadamente como juntas) não assinalaram significância. Os resultados das análises conjuntas agrupadas da variância dos três caracteres (Tabela 21) não estiveram, entretanto, de acordo com os testes de comparação de médias envolvendo as progênies das duas recombinações, pois os quadrados médios das recombinações haviam assinalado significância. Os testes Tukey não confirmaram, portanto, os resultados previamente sugeridos pelas análises conjuntas agrupadas, pois os valores das diferenças mínimas significativas superaram todos os contrastes verificados entre as médias obtidas. 
Conclui-se, assim, para os três caracteres avaliados, a partir dos testes de comparação de médias, que um ciclo adicional de recombinação não produziu nenhuma alteração estatisticamente significativa nas médias das progênies de meios irmãos e de irmãos germanos (Tabela 22).

As estimativas, para os caracteres altura da planta e altura da espiga, da variância genética de progênies, da variância das interações de progênies com ambientes, da variância fenotípica de médias de progênies, todas em $(\mathrm{cm} / \mathrm{planta})^{2}$, da herdabilidade ao nível de médias de progênies, em porcentagem, e da resposta esperada à seleção entre progênies (tanto em valor absoluto, em $\mathrm{cm} /$ planta, como em porcentagem da média) foram obtidas para cada uma das quatro classes de progênie. A estimativa da variância do erro experimental, também em $(\mathrm{cm} / \text { planta })^{2}$, comum às quatro classes, também foi obtida. Todas as estimativas, com os respectivos intervalos de confiança (com exceção daquelas da resposta esperada à seleção), encontram-se nas Tabelas 24 e 25 , respectivamente. Para o caráter posição relativa da espiga, caráter adimensional, as estimativas dos mesmos parâmetros genéticos e fenotípicos mencionados encontram-se na Tabela 26.

Para a altura da planta, a estimativa da variância genética de progênies alcançou os valores de 15,58 (cm/planta) $)^{2}$ e $23,14(\mathrm{~cm} / \text { planta) })^{2}$, para as progênies de meios irmãos 1 e de meios irmãos 2 , respectivamente. Tais estimativas são inferiores àquelas relatadas por Lima Neto (1994) e Takeda (1997), porém próximas a outras verificadas por Pellicano (1990), Arias (1995), Camargo Buitrago (1996) e Takeda (1997). As estimativas da variância genética das progênies de irmãos germanos 1 e das progênies de irmãos germanos 2 foram, respectivamente, 53,83 (cm/planta) ${ }^{2}$ e 43,77 $(\mathrm{cm} / \text { planta })^{2}$, resultados que se aproximam de um dos encontrados por Benitez Torres (1986) e daqueles encontrados por Lima Neto (1994), porém inferiores àqueles obtidos por Araújo (1992), Nass (1992), Farias Neto (1995) e Rezende (1997). A variância das interações de progênies com ambientes foi ligeiramente positiva, $0,97(\mathrm{~cm} / \text { planta })^{2}$, para as progênies de meios irmãos 1, e um pouco maior, porém também de baixa magnitude, $9,55(\mathrm{~cm} / \text { planta })^{2}$, para as progênies de meios irmãos 2 . As estimativas sugerem que as progênies de meios irmãos não foram afetadas de maneira significativa pelos ambientes. 
Os valores verificados para as progênies de irmãos germanos 1 e de irmãos germanos 2 foram negativos, respectivamente $-14,84\left(\mathrm{~cm} / \text { planta) }{ }^{2} \text { e }-11,57 \text { ( } \mathrm{cm} / \text { planta }\right)^{2}$, revelando, portanto, que o parâmetro é estatisticamente nulo, ou seja, os ambientes não exerceram significativa influência no comportamento das progênies de irmãos germanos. A variância fenotípica de médias de progênies oscilou suavemente de 48,16 (cm/planta) ${ }^{2}$ para 58,58 (cm/planta) $)^{2}$, das progênies de meios irmãos 1 para as progênies de meios irmãos 2. A oscilação verificada das progênies de irmãos germanos 1 para as progênies de irmãos germanos 2 foi da mesma magnitude observada para as progênies de meios irmãos - o parâmetro, do $1^{\circ}$ para o $2^{\circ}$ ciclo, oscilou de $81,14(\mathrm{~cm} / \text { planta })^{2}$ para 72,17 $(\mathrm{cm} / \text { planta })^{2}$. Os coeficientes de herdabilidade ao nível de médias de progênies foram $32,35 \%$ e $39,50 \%$, para as progênies de meios irmãos 1 e de meios irmãos 2 , respectivamente. Tais valores são próximos daqueles reportados por Mariote (1993) e superiores às estimativas relatadas por Zanotto (1986) e por Silva (1990), mas inferiores àquelas descritas por Pellicano (1990), Lima Neto (1994), Arias (1995), Camargo Buitrago (1996) e Takeda (1997). As estimativas da herdabilidade ao nível de médias de progênies foram $66,34 \%$ e $60,65 \%$, para as progênies de irmãos germanos 1 e de irmãos germanos 2, respectivamente, próximas, portanto, daquelas obtidas por Lima Neto (1994) e de uma das estimativas encontradas por Farias Neto (1995), mas inferiores àquelas descritas por Rezende (1997). A resposta esperada à seleção entre progênies apresentou um pequeno acréscimo, das progênies de meios irmãos 1 para as progênies de meios irmãos 2 , de $3,93 \mathrm{~cm} /$ planta para $5,29 \mathrm{~cm} /$ planta ou, em percentual da média, de $1,76 \%$ para $2,37 \%$ e, das progênies de irmãos germanos 1 para as progênies de irmãos germanos 2 , um pequeno decréscimo de $10,46 \mathrm{~cm} /$ planta para 9,02 $\mathrm{cm} /$ planta ou, em percentual da média, de $4,65 \%$ para $4,05 \%$.

Para a altura da espiga, os valores da variância genética de progênies foram $9,52(\mathrm{~cm} / \text { planta })^{2}$ e $10,26(\mathrm{~cm} / \text { planta })^{2}$, para as progênies de meios irmãos 1 e de meios irmãos 2, respectivamente. Tais estimativas são inferiores a algumas relatadas, na literatura, por Arias (1995), Camargo Buitrago (1996) e Takeda (1997), porém próximas a algumas reportadas por Pellicano (1990) e Lima Neto (1994), assim como a outros valores obtidos também por Arias (1995), Camargo Buitrago (1996) e Takeda (1997). 
As estimativas da variância genética das progênies de irmãos germanos 1 e de irmãos germanos 2 foram, respectivamente, 22,69 (cm/planta) ${ }^{2}$ e 20,09 (cm/planta) ${ }^{2}$, valores próximos aos relatados por Lima Neto (1994), mas inferiores àqueles relatados por Araújo (1992), Nass (1992), Farias Neto (1995) e Rezende (1997). Os valores obtidos para a variância das interações de progênies com ambientes foram 11,98 (cm/planta) ${ }^{2} \mathrm{e}$ $0,83(\mathrm{~cm} / \text { planta })^{2}$, para as progênies de meios irmãos 1 e de meios irmãos 2 , respectivamente, enquanto que, para as progênies de irmãos germanos 1 e de irmãos germanos 2, foram 1,92 (cm/planta) ${ }^{2}$ e 3,15 (cm/planta) ${ }^{2}$, também respectivamente. Todas as estimativas foram, assim, de baixa magnitude, o que é um indício de que as progênies, de forma geral, não interagiram de maneira significativa com os ambientes. A variância fenotípica de médias de progênies praticamente não se alterou, tanto nas progênies de meios irmãos como nas progênies de irmãos germanos. Nas progênies de meios irmãos 1 e de meios irmãos 2 , as estimativas obtidas foram $29,16(\mathrm{~cm} / \text { planta })^{2}$ e $26,18(\mathrm{~cm} / \text { planta })^{2}$, respectivamente, enquanto que, nas progênies de irmãos germanos 1 e de irmãos germanos 2 , as estimativas encontradas foram 38,97 (cm/planta) ${ }^{2}$ e 36,78 $(\mathrm{cm} / \text { planta })^{2}$, também respectivamente. Os coeficientes de herdabilidade ao nível de médias de progênies foram 32,65 \% e 39,19 \%, nas progênies de meios irmãos 1 e de meios irmãos 2, respectivamente, estimativas próximas àquelas relatadas por Aguilar Moran (1984), Zanotto (1986) e Mariote (1993). Os valores encontrados são superiores àqueles verificados por Silva (1990), mas inferiores àqueles constatados por Pellicano (1990), Lima Neto (1994), Arias (1995), Camargo Buitrago (1996) e Takeda (1997). Para as progênies de irmãos germanos 1 e de irmãos germanos 2 , os valores encontrados foram, respectivamente, 58,22\% e 54,62 \%, próximos às estimativas obtidas por Lima Neto (1994) e Farias Neto (1995). A resposta esperada à seleção entre progênies não apresentou nenhuma modificação substancial das progênies de meios irmãos 1 para as progênies de meios irmãos 2, correspondendo a $3,09 \mathrm{~cm} /$ planta e a $3,51 \mathrm{~cm} /$ planta ou, em percentual da média, a $2,54 \%$ e a $2,93 \%$, respectivamente. De maneira análoga, nenhuma alteração expressiva das progênies de irmãos germanos 1 para as prcgênies de irmãos germanos 2 foi verificada - a resposta à seleção foi de $6,36 \mathrm{~cm} /$ planta e de 5,80 $\mathrm{cm} /$ planta ou, em percentual da média, de $5,21 \%$ e de $4,84 \%$, respectivamente. 
Para a posição relativa da espiga, as estimativas da variância genética de progênies foram $0,69 \times 10^{-4}$, para as progênies de meios irmãos 1 , e $0,05 \times 10^{-4}$, para as progênies de meios irmãos 2 , ambas inferiores aos valores obtidos por Souza Júnior et al. (1980a), Arias (1995), Cunha (1996) e Takeda (1997), mas relativamente próximas de algumas estimativas encontradas por Lima Neto (1994). Para as progênies de irmãos germanos 1 e de irmãos germanos 2 , o parâmetro apresentou os valores de $0,43 \times 10^{-4} \mathrm{e}$ $0,49 \times 10^{-4}$, respectivamente, semelhantes, portanto, a uma das estimativas relatadas por Lima Neto (1994), mas inferiores, todavia, às estimativas relatadas por Rezende (1997). A variância das interações de progênies com ambientes decresceu, das progênies de meios irmãos 1 para as progênies de meios irmãos 2 , de $0,44 \times 10^{-4}$ para $-0,37 \times 10^{-4}$. A estimativa negativa para as progênies de meios irmãos 2 revela que o parâmetro é estatisticamente nulo. Os valores expressos pelas progênies de irmãos germanos 1 e de irmãos germanos 2 foram, respectivamente, $0,69 \times 10^{-4}$ e $0,94 \times 10^{-4}$. Contrariamente ao ocorrido com as progênies de meios irmãos, verificou-se, nas progênies de irmãos germanos, uma elevação na magnitude do parâmetro, embora de pouca relevância. A variância fenotípica de médias de progênies decresceu de $2,05 \times 10^{-4}$ para $1,14 \times 10^{-4}$, das progênies de meios irmãos 1 para as progênies de meios irmãos 2. Entretanto, das progênies de irmãos germanos 1 para as progênies de irmãos germanos 2 , o parâmetro permaneceu estável, revelando os valores de $1,87 \times 10^{-4}$ e $2,02 \times 10^{-4}$, respectivamente. A herdabilidade ao nível de médias de progênies apresentou uma acentuada oscilação, tal qual a variância genética de progênies, das progênies de meios irmãos 1 para as progênies de meios irmãos 2, decaindo vertiginosamente de 33,66 \% para 4,39 \%, estimativas muito inferiores àquelas constatadas por Arias (1995) e Takeda (1997). Das progênies de irmãos germanos 1 para as progênies de irmãos germanos 2, o parâmetro revelou-se estável, apresentando, como valores, 22,99\% e $24,26 \%$, respectivamente, números praticamente idênticos à estimativa calculada por Lima Neto (1994), mas muito inferiores às estimativas registradas por Rezende (1997). Ainda como reflexo do abrupto decréscimo notado na estimativa da variância genética das progênies de meios irmãos do $1^{\circ}$ para o $2^{\mathfrak{0}}$ ciclo de recombinação, a resposta esperada à seleção decaiu de $84,34 \times 10^{-4}$ para $8,20 \times 10^{-4}$ ou, em percentual da média, de $1,56 \%$ para $0,15 \%$. 
Contudo, das progênies de irmãos germanos 1 para as progênies de irmãos germanos 2 , o parâmetro não variou sensivelmente, demonstrando, portanto, estabilidade. Os valores encontrados foram, respectivamente, $55,03 \times 10^{-4}$ e $60,33 \times 10^{-4}$ ou, em percentual da média, $1,02 \%$ e $1,12 \%$.

Os testes $\mathrm{F}$ para comparação da variância genética das progênies de meios irmãos do primeiro ciclo de recombinação com a variância genética das progênies de meios irmãos do segundo ciclo de recombinação e para comparação da variância genética das progênies de irmãos germanos do primeiro ciclo de recombinação com a variância genética das progênies de irmãos germanos do segundo ciclo de recombinação encontram-se na Tabela 28. Constata-se, para a altura da planta e a altura da espiga, que a variância genética das progênies praticamente não se alterou, apresentando um pequeno acréscimo, nas progênies de meios irmãos - respectivamente de 15,58 para $23,14$ (cm/planta $)^{2}$ e de 9,52 para 10,26 (cm/planta $)^{2}$-, e um discreto decréscimo, nas progênies de irmãos germanos - respectivamente de 53,83 para $43,77\left(\mathrm{~cm} /\right.$ planta) ${ }^{2}$ e de 22,69 para 20,09 (cm/planta) $)^{2}$. Os testes $\mathrm{F}$ calculados foram inferiores aos valores $\mathrm{F}$ tabelados, o que demonstra que a variabilidade genética da população não foi incrementada com um ciclo adicional de recombinação. Para a posição relativa da espiga, a variância genética das progênies de meios irmãos diminuiu consideravelmente do primeiro para o segundo ciclo de recombinação (de $0,69 \times 10^{-4}$ para $0,05 \times 10^{-4}$ ), todavia o valor $\mathrm{F}$ tabelado foi superior ao teste $\mathrm{F}$ calculado, indicando, portanto, que o parâmetro não decaiu significativamente do primeiro para o segundo ciclo. Nas progênies de irmãos germanos, no entanto, a variância genética praticamente não variou, apresentando um pequeno acréscimo do primeiro para o segundo ciclo de recombinação (de $0,43 \times 10^{-4}$ para $0,49 \times 10^{-4}$ ). $\mathrm{O}$ teste $\mathrm{F}$ calculado também foi menor que o valor $\mathrm{F}$ tabelado, o que sugere que não houve incremento na variabilidade genética. Para os três caracteres, conclui-se que um ciclo adicional de recombinação não foi eficaz nem para modificar as médias das progênies de meios irmãos e de irmãos germanos, com exceção apenas da média das progênies de meios irmãos, no ambiente 2 , para a posição relativa da espiga (Tabelas $16,17,18$ e 22), nem para aumentar a variabilidade genética da população, pois os testes $\mathrm{F}$ efetuados foram não significativos. 
Para a altura da planta e a altura da espiga, os coeficientes de herdabilidade e as respostas esperadas à seleção também não se alteraram substancialmente, permanecendo praticamente com os mesmos valores do primeiro para o segundo ciclo, tanto nas progênies de meios irmãos como nas progênies de irmãos germanos, e, portanto, apresentando o mesmo comportamento da variância genética (Tabelas 24 e 25). Para a posição relativa da espiga, entretanto, em virtude do decréscimo sofrido pela variância genética das progênies de meios irmãos, do primeiro para o segundo ciclo, o coeficiente de herdabilidade e a resposta esperada à seleção também diminuíram bruscamente. Contudo, já que o teste $\mathrm{F}$ calculado para a variância genética não acusou significância, a redução observada nos dois parâmetros mencionados também não deve ser considerada relevante. Nas progênies de irmãos germanos, não houve nenhuma mudança apreciável nem no coeficiente de herdabilidade e nem na resposta esperada à seleção, assim como ocorreu com a variância genética, que não demonstrou nenhuma alteração expressiva (Tabela 26).

Verifica-se que os caracteres altura da planta e altura da espiga apresentaram a mesma tendência com um ciclo adicional de recombinação, pois, enquanto para as progênies de meios irmãos a variância genética, o coeficiente de herdabilidade e a resposta à seleção (em percentual da média) revelaram um acréscimo, embora muito discreto, para as progênies de irmãos germanos os parâmetros mencionados sofreram um decréscimo, embora também de baixa magnitude. Sabendo-se que os dois referidos caracteres são altamente correlacionados, esperava-se realmente que apresentassem o mesmo comportamento. Assim, mesmo que o acréscimo e o decréscimo nos parâmetros não tenham sido significativos, percebe-se que os caracteres demonstraram a mesma tendência. O caráter posição relativa da espiga, entretanto, não se comportou de maneira similar à altura da planta e à altura da espiga, pois a variância genética, o coeficiente de herdabilidade e a resposta esperada à seleção decresceram com um ciclo adicional de recombinação, nas progênies de meios irmãos, embora não significativamente, enquanto que, nas progênies de irmãos germanos, revelaram um acréscimo, embora também não significativo. 


\subsection{3. ÍNDICE DE ESPIGAS}

$\mathrm{O}$ número médio de espigas por planta é um caráter muito importante por apresentar alta correlação com a produção de grãos e por ser um parâmetro relevante na recomendação da densidade de plantio do cultivar (Buren et al., 1974; Duvick, 1974).

Para o índice de espigas, todos os testes Tukey efetuados entre as diversas médias obtidas, nos três ambientes, foram não significativos. Os contrastes observados entre as progênies das duas recombinações não expressaram significância, corroborando os resultados fornecidos pelas análises agrupadas da variância, através dos quadrados médios das recombinações, dos ambientes 1 e 2, que não foram significativos. Todavia, no ambiente 3 , o quadrado médio referente às recombinações foi significativo. Os testes de comparação de médias não confirmaram, no entanto, a hipótese previamente formulada de que um ciclo adicional de recombinação havia sido eficiente para modificar a média das progênies de meios irmãos e/ou a média das progênies de irmãos germanos (Tabela 14). A partir dos testes de comparação de médias, percebe-se, assim, que um ciclo adicional de intercruzamentos entre as plantas de uma população não foi efetivo para alterar as médias das progênies de meios irmãos e de irmãos germanos (Tabela 19).

Para a análise conjunta agrupada, todos os testes Tukey efetuados entre as diversas médias obtidas foram também estatisticamente não significativos. Assim, todos os contrastes observados entre as progênies das duas recombinações (progênies do $1^{\circ}$ ciclo $\mathrm{x}$ progênies do $2^{-}$ciclo, considerando-se as progênies de meios irmãos e as progênies de irmãos germanos tanto separadamente como juntas) não revelaram significância. Os testes de comparação de médias envolvendo as progênies das duas recombinações confirmaram, portanto, os resultados fornecidos pela análise conjunta agrupada da variância (Tabela 21 ), através do quadrado médio das recombinações, que não expressou significância. Conclui-se, assim, a partir dos testes de comparação de médias, que um ciclo adicional de recombinação não produziu nenhuma alteração estatisticamente significativa nas médias das progênies de meios irmãos e de irmãos germanos (Tabela 22). 
As estimativas da variância genética de progênies, da variância das interações de progênies com ambientes, da variância fenotípica de médias de progênies, da herdabilidade ao nível de médias de progênies, em porcentagem, e da resposta esperada à seleção entre progênies (tanto em valor absoluto como em porcentagem da média) foram obtidas para cada uma das quatro classes de progênie. A estimativa da variância do erro experimental, comum às quatro classes, também foi obtida. Todas as estimativas, com os respectivos intervalos de confiança (com exceção daquelas da resposta esperada à seleção), encontram-se na Tabela 27.

A variância genética de progênies diminuiu de $0,17 \times 10^{-2}$ para $-0,12 \times 10^{-2}$, das progênies de meios irmãos 1 para as progênies de meios irmãos 2, atingindo, pois, um valor negativo. A estimativa para as progênies de meios irmãos 2 é, na verdade, estatisticamente nula. A estimativa para as progênies de meios irmãos $1,0,17 \times 10^{-2}$, está próxima dos valores obtidos por Souza Júnior et al. (1980a), Pellicano (1990), Lima Neto (1994), Arias (1995) e Takeda (1997). As estimativas para as progênies de irmãos germanos 1 e de irmãos germanos $2,0,20 \times 10^{-2}$ e $0,35 \times 10^{-2}$, respectivamente, se assemelham às registradas por Lima Neto (1994) e Rezende (1997).

A variância das interações de progênies com ambientes apresentou uma substancial elevação, das progênies de meios irmãos 1 para as progênies de meios irmãos 2 , de $-0,33 \times 10^{-2}$ para $0,43 \times 10^{-2}$. O parâmetro, para as progênies de meios irmãos 1, pode ser considerado como estatisticamente nulo. Das progênies de irmãos germanos 1 para as progênies de irmãos germanos 2 , o processo verificado foi exatamente o inverso, ou seja, constatou-se uma diminuição do parâmetro de $0,65 \times 10^{-2}$ para $0,19 \times 10^{-2}$, interpretada como uma decorrência de interações pouco significativas entre as progênies de irmãos germanos 2 e os ambientes.

A variância fenotípica de médias de progênies apresentou-se estável, tanto nas progênies de meios irmãos como nas progênies de irmãos germanos. Nas progênies de meios irmãos, o parâmetro oscilou de $0,57 \times 10^{-2}$ para $0,54 \times 10^{-2}$, do $1^{\circ}$ para o $2^{\circ}$ ciclo de recombinação, enquanto que, nas progênies de irmãos germanos, o parâmetro oscilou de $0,93 \times 10^{-2}$ para $0,92 \times 10^{-2}$, do $1^{\circ}$ para o $2^{\circ}$ ciclo de recombinação. 
O coeficiente de herdabilidade ao nível de médias de progênies apresentou, para as progênies de meios irmãos 1 , o valor de $29,82 \%$, estimativa próxima daquelas relatadas por Pellicano (1990), Arias (1995), Lima Neto (1994) e Takeda (1997). O valor para as progênies de meios irmãos 2 não pôde ser calculado, em virtude da estimativa negativa da variância genética de tais progênies. Para as progênies de irmãos germanos 1 e de irmãos germanos 2, os valores encontrados foram, respectivamente, $21,51 \%$ e $38,04 \%$, verificando-se, assim, um aumento na estimativa do $1^{\circ}$ para o $2^{-0}$ ciclo de recombinação, tal qual aconteceu com a variância genética de tais progênies. Rezende (1997) obteve uma estimativa intermediária entre os dois valores.

A resposta esperada à seleção entre progênies foi equivalente a $3,94 \times 10^{-2}, \mathrm{o}$ que eqüivaleria a um acréscimo de 3,94 espigas por 100 plantas, ou a 3,69\%, em percentual da média, para as progênies de meios irmãos 1. Para as progênies de meios irmãos 2, a resposta esperada não pôde ser obtida, em função da estimativa negativa da variância genética de tais progênies. Das progênies de irmãos germanos 1 para as progênies de irmãos germanos 2 , o parâmetro seguiu a mesma tendência da variância genética. Assim, do $1^{\circ}$ para o $2^{\underline{0}}$ ciclo, a resposta esperada à seleção entre progênies sofreu uma elevação, em números absolutos, de $3,63 \times 10^{-2}$ para $6,39 \times 10^{-2}$, valores que eqüivaleriam a acréscimos de 3,63 e 6,39 espigas por 100 plantas, respectivamente, ou, em percentual da média, de 3,40\% para 6,02 \%.

$\mathrm{O}$ teste $\mathrm{F}$ para comparação da variância genética das progênies de irmãos germanos do primeiro ciclo de recombinação com a variância genética das progênies de irmãos germanos do segundo ciclo de recombinação foi realizado. O teste $\mathrm{F}$ para comparação das variâncias genéticas das progênies de meios irmãos dos dois ciclos de recombinação, no entanto, não pôde ser realizado, em virtude do valor negativo da variância genética do $2^{2}$ ciclo (Tabela 28). Em relação às progênies de irmãos germanos, o teste $\mathrm{F}$ realizado revela que o acréscimo verificado do $1^{\circ}$ para o $2^{-}$ciclo (de $0,20 \times 10^{-2}$ para $0,35 \times 10^{-2}$ ) não foi estatisticamente significativo, já que a estimativa obtida foi inferior ao correspondente valor tabelado. Conclui-se, assim, para o índice de espigas, que um ciclo adicional de recombinação não proporcionou nenhuma alteração devidamente expressiva na variância genética das progênies de irmãos germanos. 
Nenhuma modificação relevante foi também constatada nem na média das progênies de meios irmãos nem na média das progênies de irmãos germanos, conforme os testes Tukey efetuados (Tabelas 19 e 22). Para as progênies de meios irmãos do $2^{0}$ ciclo, não foi possivel obter o coeficiente de herdabilidade e a resposta esperada à seleção, em decorrência da estimativa negativa da variância genética. Para as progênies de irmãos germanos, os dois parâmetros, assim como a variância genética, apresentaram uma substancial elevação no $2^{\circ}$ ciclo. Contudo, já que o acréscimo verificado na variância genética de progênies não foi significativo, conforme o teste $\mathrm{F}$ realizado, também o aumento constatado no coeficiente de herdabilidade e na resposta esperada à seleção não deve ser considerado expressivo. Para as progênies de meios irmãos, verifica-se que não foi possível realizar o teste $\mathrm{F}$ em virtude da estimativa negativa da variância genética do $2^{2}$ ciclo. No entanto, o decréscimo constatado na estimativa de tal parâmetro e o aumento não significativo observado nas progênies de irmãos germanos permitem concluir, assim, que um ciclo adicional de recombinação não foi eficaz para elevar a variabilidade genética da população, como também não demonstrou eficiência para modificar a média populacional do índice de espigas (Tabela 27).

\subsection{CORRELAÇÕES GENÉTICAS E FENOTÍPICAS}

A correlação entre caracteres visualizada diretamente ao nível de um experimento é de natureza fenotípica, a qual se deve a dois fatores, os genéticos e os ambientais. No melhoramento de plantas, a correlação genética entre caracteres requer, evidentemente, uma maior atenção, uma vez que, em geral, aprimoram-se os materiais genéticos para um conjunto de caracteres simultaneamente. A correlação genética pode ser causada por efeitos pleiotrópicos dos genes ou por desequilibrio de ligação. A pleiotropia é uma causa permanente, enquanto que o desequilíbrio de ligação pode gerar correlações transitórias, manifestando-se especialmente nas gerações iniciais de populações obtidas de cruzamentos de genitores geneticamente divergentes (Falconer, 1989; Vencovsky \& Barriga, 1992). 
As estimativas dos coeficientes de correlação genética e dos coeficientes de correlação fenotípica de médias de progênies relativas às dez associações possíveis entre os cinco caracteres analisados e para as quatro classes de progênie avaliadas, com os respectivos limites inferiores e limites superiores dos intervalos de confiança e com os respectivos testes de significância, encontram-se na Tabela 30.

Os coeficientes de correlação genética entre o peso de espigas e a altura da planta (PE x AP) foram 0,49 e 0,47, para as progênies de meios irmãos 1 e de meios irmãos 2, e 0,42 e 0,50, para as progênies de irmãos germanos 1 e de irmãos germanos 2 , respectivamente. As quatro estimativas obtidas foram estatisticamente significativas (P $\leq 1 \%$ ). Os intervalos de confiança associados mostram que os valores encontrados não diferiram entre si. Os coeficientes de correlação fenotípica de médias de progênies, 0,35 e 0,28 , para as progênies de meios irmãos 1 e de meios irmãos 2 , e 0,34 e 0,36, para as progênies de irmãos germanos 1 e de irmãos germanos 2 , respectivamente, foram inferiores aos coeficientes de correlação genética, porém apresentaram o mesmo padrão de comportamento.

Os coeficientes de correlação genética entre o peso de espigas e a altura da espiga (PE x AE) foram 0,39 e 0,41, para as progênies de meios irmãos 1 e de meios irmãos 2 , respectivamente, e 0,34 , tanto para as progênies de irmãos germanos 1 como para as progênies de irmãos germanos 2. A correlação genética PE x AE apresentou tanto estimativas semelhantes como um comportamento similar à correlação PE x AP, fato realmente esperado já que os caracteres altura da planta e altura da espiga possuem valores elevados para a correlação genética. As quatro estimativas encontradas foram também significativas ( $\mathrm{P} \leq 1 \%$ ). Os intervalos de confiança associados se sobrepõem, mostrando, portanto, que as estimativas obtidas não diferiram entre si. Os coeficientes de correlação fenotípica de médias de progênies, 0,31 e 0,27 , para as progênies de meios irmãos 1 e de meios irmãos 2, e 0,30 e 0,29, para as progênies de irmãos germanos 1 e de irmãos germanos 2 , respectivamente, foram levemente inferiores aos coeficientes de correlação genética, entretanto o padrão de comportamento apresentado foi exatamente o mesmo. 
A correlação genética entre o peso de espigas e a posição relativa da espiga (PE x PR) apresentou, como coeficientes, 0,33 e 0,29, para as progênies de meios irmãos 1 e de meios irmãos 2 , e 0,26 e 0,22, para as progênies de irmãos germanos 1 e de irmãos germanos 2 , respectivamente. Apenas os valores obtidos para as progênies de meios irmãos 1 e de irmãos germanos 1 foram significativos $(\mathrm{P} \leq 1 \%$ e $\mathrm{P} \leq 5 \%$, respectivamente). A semelhança notada entre os intervalos de confiança sugere que as estimativas não diferiram entre si. Os coeficientes de correlação fenotípica de médias de progênies foram um pouco inferiores - 0,19 e 0,13 , para as progênies de meios irmãos 1 e de meios irmãos 2, e 0,16 e 0,13, para as progênies de irmãos germanos 1 e de irmãos germanos 2 , respectivamente. As quatro estimativas obtidas não foram significativas.

A correlação genética entre o peso de espigas e o índice de espigas (PE $\times$ IE) apresentou, como coeficientes, 0,73 , para as progênies de meios irmãos 1 , e 0,66 e 0,63, para as progênies de irmãos germanos 1 e de irmãos germanos 2 , respectivamente. $\mathrm{O}$ valor referente às progênies de meios irmãos 2 não pôde ser obtido, em decorrência da estimativa negativa da variância genética de tais progênies, para o índice de espigas. Todas as estimativas foram significativas $(\mathrm{P} \leq 1 \%)$. A similaridade dos intervalos de confiança sugere que as estimativas não diferiram entre si. Os coeficientes de correlação fenotípica de médias de progênies foram 0,53 e 0,49 , para as progênies de meios irmãos 1 e de meios irmãos 2 , e 0,45 e 0,49 , para as progênies de irmãos germanos 1 e de irmãos germanos 2 , respectivamente. As estimativas foram inferiores àquelas obtidas para a correlação genética, contudo o padrão de comportamento foi o mesmo.

Os coeficientes de correlação genética entre a altura da planta e a altura da espiga ( $\mathrm{AP} \times \mathrm{AE}$ ) foram 0,87 e 0,97, para as progênies de meios irmãos 1 e de meios irmãos 2 , e 0,98 e 0,97 , para as progênies de irmãos germanos 1 e de irmãos germanos 2 , respectivamente. As quatro estimativas foram significativas ( $\mathrm{P} \leq 1 \%)$. Os intervalos de confiança associados indicam que os valores não diferiram entre si. Os coeficientes de correlação fenotípica de médias de progênies foram 0,81 e 0,89 , para as progênies de meios irmãos 1 e de meios irmãos 2 , respectivamente, e 0,88 , tanto para as progênies de irmãos germanos 1 como para as progênies de irmãos germanos 2 , estimativas quase tão altas quanto aquelas da correlação genética. O padrão de comportamento foi o mesmo. 
A correlação genética entre a altura da planta e a posição relativa da espiga (AP x PR) apresentou, como coeficientes, 0,51 e 0,58, para as progênies de meios irmãos 1 e de meios irmãos 2 , e 0,45 e 0,57, para as progênies de irmãos germanos 1 e de irmãos germanos 2, respectivamente. Excetuando o valor correspondente às progênies de meios irmãos 2, não significativo, todas as estimativas obtidas foram estatisticamente significativas $(\mathrm{P} \leq 1 \%$ ). Para as progênies de meios irmãos, a similaridade entre as estimativas encontradas e os intervalos de confiança associados sugere que os valores não diferiram entre si. Para as progênies de irmãos germanos, observa-se que houve um acréscimo, na estimativa do parâmetro, do $1^{\circ}$ para o $2^{\circ}$ ciclo de recombinação, como também um deslocamento ascendente do intervalo de confiança associado. Em relação à significância das estimativas, o valor encontrado para as progênies de meios irmãos do $2^{\underline{0}}$ ciclo não foi significativo, embora superior àquele obtido para o $1^{0}$ ciclo e àqueles obtidos para as progênies de irmãos germanos, significativos $(\mathrm{P} \leq 1 \%)$, possivelmente em virtude da baixa estimativa verificada para a variância genética do caráter PR nas progênies de meios irmãos do $2^{\circ}$ ciclo. Os coeficientes de correlação fenotípica de médias de progênies foram 0,21 e 0,24 , para as progênies de meios irmãos 1 e de meios irmãos 2 , e 0,21 e 0,26, para as progênies de irmãos germanos 1 e de irmãos germanos 2 , respectivamente. $O$ valor para as progênies de irmãos germanos 2 foi significativo ( $\mathrm{P} \leq 1 \%$ ), tal como os demais, mas a outro nível $(\mathrm{P} \leq 5 \%)$. O padrão de comportamento foi diferente daquele das correlações genéticas.

A correlação genética entre a altura da planta e o índice de espigas (AP x IE) apresentou, como coeficientes, 0,17 , para as progênies de meios irmãos 1 , e 0,09 e 0,07, para as progênies de irmãos germanos 1 e de irmãos germanos 2 , respectivamente. A estimativa para as progênies de meios irmãos 2 não pôde ser obtida, em virtude da variância genética negativa de tais progênies, para o índice de espigas. Todos os valores foram não significativos. Os intervalos de confiança mostram que as estimativas não diferiram entre si. Os coeficientes de correlação fenotípica de médias de progênies foram 0,12 e 0,07, para as progênies de meios irmãos 1 e de meios irmãos 2, e 0,06 e 0,05 , para as progênies de irmãos germanos 1 e de irmãos germanos 2 , respectivamente, valores similares aos da correlação genética. O padrão de comportamento foi o mesmo. 
A correlação genética entre a altura da espiga e a posição relativa da espiga (AE x PR) apresentou, como coeficientes, 0,67 e 0,76, para as progênies de meios irmãos 1 e de meios irmãos 2, e 0,67 e 0,73, para as progênies de irmãos germanos 1 e de irmãos germanos 2, respectivamente. Excetuando o valor referente às progênies de meios irmãos 2 , não significativo, todas as estimativas obtidas foram estatisticamente significativas $(\mathrm{P} \leq 1 \%)$. Os intervalos de confiança associados indicam que os valores não diferiram entre si. Em relação à significância das estimativas, o valor encontrado para as progênies de meios irmãos do $2^{\circ}$ ciclo não foi significativo, embora superior àquele obtido para o $1^{0}$ ciclo e também àqueles obtidos para as progênies de irmãos germanos, significativos ( $\mathrm{P} \leq 1 \%$ ), assim como se verificou com a correlação AP $\mathrm{x} P \mathrm{R}$. De maneira análoga, o fenômeno deve ter se repetido possivelmente em virtude da baixa estimativa verificada para a variância genética do caráter PR nas progênies de meios irmãos do $2^{0}$ ciclo. Os coeficientes de correlação fenotípica de médias de progênies foram 0,73 e 0,63 , para as progênies de meios irmãos 1 e de meios irmãos 2 , e 0,65 e 0,68 , para as progênies de irmãos germanos 1 e de irmãos germanos 2 , respectivamente. As estimativas foram significativas $(\mathrm{P} \leq 1 \%)$ e muito próximas daquelas da correlação genética. $\mathrm{O}$ padrão de comportamento verificado foi semelhante àquele constatado para as correlações genéticas, embora tenha havido uma pequena diferença em relação à significância das estimativas.

A correlação genética entre a altura da espiga e o índice de espigas (AE x IE) apresentou, como coeficientes, 0,25 , para as progênies de meios irmãos 1 , e 0,14 e 0,20, para as progênies de irmãos germanos 1 e de irmãos germanos 2 , respectivamente. A estimativa para as progênies de meios irmãos 2 não pôde ser obtida, em virtude da variância genética negativa de tais progênies, para o índice de espigas. Todas as estimativas foram não significativas. Os intervalos de confiança associados revelam que os valores não diferiram entre si. Os coeficientes de correlação fenotípica de médias de progênies foram 0,19 e 0,11 , para as progênies de meios irmãos 1 e de meios irmãos 2 , respectivamente, e 0,10 , tanto para as progênies de irmãos germanos 1 como para as progênies de irmãos germanos 2 , estimativas de baixa magnitude, assim como aquelas da correlação genética. O padrão de comportamento foi basicamente o mesmo. 
Os coeficientes de correlação genética entre a posição relativa da espiga e o indice de espigas ( $\mathrm{PR} \times \mathrm{IE}$ ) foram 0,18, para as progênies de meios irmãos 1 , e $0,11 \mathrm{e}$ 0,06 , para as progênies de irmãos germanos 1 e de irmãos germanos 2 , respectivamente. $\mathrm{O}$ valor referente às progênies de meios irmãos 2 não pôde ser obtido, porque tais progênies apresentaram variância genética negativa no índice de espigas. As estimativas foram não significativas. Os intervalos de confiança associados sugerem que os valores não diferiram entre si. Os coeficientes de correlação fenotípica de médias de progênies foram 0,16 e 0,08, para as progênies de meios irmãos 1 e de meios irmãos 2, e 0,09 e 0,05 , para as progênies de irmãos germanos 1 e de irmãos germanos 2 , respectivamente, estimativas próximas daquelas encontradas para os coeficientes de correlação genética. O padrão de comportamento foi o mesmo apresentado pelas correlações genéticas.

Os coeficientes de correlação genética envolvendo todos os pares entre os caracteres avaliados apresentaram valores próximos daqueles normalmente encontrados na literatura, em populações de milho, tais como Souza Júnior et al. (1980b), Sampaio (1986), Bianco et al. (1987), Araújo (1992), Lima Neto (1994), Farias Neto (1995), Pinto (1996), Cunha (1996) e Rezende (1997).

O desequilibrio de ligação em uma determinada população pode ser causado pela seleção (Falconer, 1989). Assim, como o desequilibrio de ligação pode provocar o aparecimento de correlações genéticas transitórias, espera-se que, em populações sob seleção, as correlações genéticas permanentes devidas aos efeitos pleiotrópicos possam vir a ser perturbadas pelas ligações gênicas. Nos programas de melhoramento genético, portanto, a seleção dos genótipos superiores da população avaliada pode desencadear o desequilibrio de ligação, principalmente se a intensidade empregada for muito elevada e, consequentemente, o novo tamanho efetivo populacional for, assim, muito pequeno. Esperava-se, portanto, que as correlações genéticas com um e com dois ciclos de recombinação diferissem. Entretanto, no presente trabalho, um ciclo adicional de recombinação não modificou o panorama geral das correlações genéticas, já que as estimativas encontradas no $1^{\circ}$ e no $2^{\circ}$ ciclo foram muito próximas. Evidencia-se que o desequilíbrio gerado pela seleção não deve apresentar magnitude muito elevada, embora a generalização só seja possível se outros estudos confirmarem os resultados obtidos. 


\subsection{CONSIDERAÇÕES GERAIS}

A seleção recorrente é uma metodologia muito importante no melhoramento de populações de milho, pois visa prepará-las para servir como fontes de linhagens e de híbridos. Diversos aspectos das fases que compõem um ciclo de seleção recorrente em milho já foram estudados, como o tipo de progênie que constituirá a unidade de seleção e a unidade de recombinação, o número adequado de repetições e de locais para avaliação das progênies, o qual é limitado pela quantidade de sementes, o número ideal de progênies (Lima Neto, 1994; Pinto, 1996), o tamanho apropriado da parcela (Chaves \& Miranda Filho, 1992) e as diferentes formas de proceder à seleção e à recombinação (Souza Júnior, 1997).

Entretanto, pratica-se normalmente apenas uma geração de recombinação entre as progênies (provenientes das plantas que produziram as progênies selecionadas) empregadas para tal fim, com o intuito assim de gerar variabilidade genética para ser aproveitada no ciclo seguinte da seleção recorrente. Os resultados teóricos da literatura mostram que a seleção e a redução do tamanho efetivo (que ocorre em conjunto com a seleção) geram o desequilíbrio de ligação, o qual altera não apenas a variância genética de uma determinada população (Weir et al., 1980), como também a covariância entre parentes (Cockerham, 1956; Schnell, 1963; Gallais, 1974) e a covariância genética entre caracteres (Falconer, 1989).

Falconer (1989) demonstra que, na presença do desequilíbrio de ligação, a variância genética causada por dois locos juntos é alterada por uma covariância, a qual representa a correlação entre os valores genotípicos, podendo ser positiva ou negativa. Assim, a variância genética que, em condições de equilibrio, eqüivale ao somatório das variâncias genéticas dos diversos locos, individualmente, na presença do desequilíbrio é modificada por um novo componente, a covariância genética que surge entre os locos em questão.

Comstock \& Robinson $(1948 ; 1952)$ esclarecem que, em populações sob presença do desequilíbrio de ligação, a magnitude dos componentes da variância genética de um determinado caráter quantitativo pode vir a sofrer algumas alterações. 
Assim, a variância genética aditiva $\left(\sigma_{A}^{2}\right)$ entre dois locos será igual ao somatório de suas variâncias aditivas individuais acrescido ou subtraído da covariância que surge entre seus efeitos aditivos $\left(\sigma_{A}^{2}=\sigma_{A 1}^{2}+\sigma_{A 2}^{2} \pm 2 C O V_{A 1 A_{2}}\right)$, enquanto a variância genética dominante $\left(\sigma_{D}^{2}\right)$ entre os tais locos será igual ao somatório de suas variâncias dominantes individuais acrescido da covariância que surge entre seus efeitos de dominância $\left(\sigma_{D}^{2}=\sigma_{D_{1}}^{2}+\sigma_{D_{2}}^{2}+2 C O V_{D_{1} D_{2}}\right)$. Portanto, a $\sigma_{A}^{2}$ poderá aumentar ou diminuir a depender das fases predominantes de ligação (fases de associação ou fases de dispersão), enquanto a $\sigma_{D}^{2}$ sempre crescerá com o desequilíbrio de ligação, seja qual for a fase predominante.

Falconer (1989) discorre sobre a alteração na magnitude da $\sigma_{A}^{2}$ em virtude do processo de seleção. A expressão que descreve a alteração é $\sigma_{A}^{2^{\prime}}=\left(1-\mathrm{h}^{2} \mathrm{k}\right) \sigma_{A}^{2}$, em que $h^{2}$ e $k$ são, respectivamente, o coeficiente de herdabilidade e uma função da intensidade de seleção. Assim, quanto maior a intensidade de seleção, maior será a redução na $\sigma_{A}^{2}$ com a seleção.

Gerações adicionais de recombinação podem alterar radicalmente o grau médio de dominância. Em populações $\mathrm{F}_{2}$ ou $\mathrm{F}_{3}$, ou seja, em populações que ainda se encontram em desequilíbrio de ligação, a $\sigma_{A}^{2}$ pode estar subestimada e a $\sigma_{D}^{2}$ pode estar superestimada, a depender das fases predominantes de ligação gênica, o que acarreta uma elevação no grau médio de dominância, o qual pode apresentar, para a produção de grãos, estimativas superiores a 1, indicando, portanto, sobredominância. Após algumas gerações de recombinação, entretanto, a população se aproxima do equilíbrio e o grau médio de dominância para a produção de grãos passa a apresentar valores em torno de 1, indicando, portanto, apenas dominância completa. Para os demais caracteres, nos quais o nível de dominância é menor, resultados semelhantes foram obtidos (Robinson et al., 1949; Robinson et al., 1955; Robinson et al., 1960; Gardner et al., 1953; Gardner \& Lonnquist, 1959; Gardner, 1963; Moll et al., 1964; Moreno-Gonzalez et al., 1975; Hallauer \& Miranda Filho, 1988). 
Todavia, para fins de melhoramento, os resultados teóricos e experimentais têm mostrado que populações $F_{2}$ não devem sofrer diversas gerações de recombinação antes de que linhagens sejam extraídas, pois a alteração na magnitude da variância genética $\left(\sigma_{G}^{2}\right)$ não é de relevância tal que justifique o aumento substancial no tempo necessário para efetuar os intercruzamentos adicionais entre as plantas (Pederson, 1974; Bos, 1977; Piper \& Fehr, 1987; Guimarães \& Fehr, 1989; Covarrubias-Prieto et al., 1989; Han \& Hallauer, 1989; Lamkey et al., 1995).

Para a seleção recorrente, contudo, há uma situação diferente daquela de populações $\mathrm{F}_{2}$, uma vez que o desequilíbrio é causado de forma conjunta pela seleção e pelo tamanho efetivo reduzido. Espera-se, portanto, a priori, que gerações adicionais de recombinação possam vir a alterar a $\sigma_{A}^{2}$ de forma que a resposta à seleção no próximo ciclo seletivo seja maior do que aquela que seria obtida com apenas uma geração de recombinação. Deve-se ressaltar, porém, que o aumento na $\sigma_{A}^{2}$ deve ser de magnitude tal que a resposta à seleção compense uma geração adicional de recombinação, já que a realização de cruzamentos entre as plantas implicaria maior dispêndio de tempo.

Os resultados das comparações das médias, das variâncias genéticas e dos coeficientes de herdabilidade dos diferentes caracteres, bem como das correlações genéticas encontradas, no presente estudo, mostraram que os parâmetros mencionados não se alteraram de forma substancial com um ciclo adicional de recombinação na população analisada. Consideradas no presente trabalho por constituírem os esquemas mais comuns em programas de seleção recorrente, nem as progênies de meios irmãos nem as progênies de irmãos germanos revelaram um aumento significativo na variância genética que compensasse a realização de um ciclo adicional de recombinação. A variância genética das progênies de meios irmãos, equivalente a um quarto da variância aditiva da população $\left(\sigma_{P M I}^{2}=\frac{1}{4} \sigma_{A}^{2}\right)$, e a variância genética das progênies de irmãos germanos, equivalente a um meio da variância aditiva mais um quarto da variância dominante da população $\left(\sigma_{P I G}^{2}=\frac{1}{2} \sigma_{A}^{2}+\frac{1}{4} \sigma_{D}^{2}\right)$ (Souza Júnior, 1989), não variaram significativamente entre os dois ciclos de recombinação, para os caracteres avaliados. 
No programa de seleção recorrente recíproca em andamento no presente trabalho, a intensidade de seleção foi de $10 \%$, ou seja, apenas vinte progênies $S_{1}$ (provenientes das plantas que forneceram as vinte melhores progênies de meios irmãos interpopulacionais) foram utilizadas para o processo de recombinação. Assim, apenas vinte genótipos da população inicial originaram a população do primeiro ciclo de recombinação. Percebe-se, então, que o tamanho efetivo populacional foi drasticamente reduzido. Esperava-se, portanto, que o montante do desequilíbrio de ligação gerado pela seleção e pela redução do tamanho efetivo populacional fosse suficiente para propiciar mudanças no padrão das correlações genéticas entre os caracteres avaliados. Contudo, a proximidade entre as estimativas encontradas e a semelhança entre os intervalos de confiança associados sugerem que o montante do desequilíbrio de ligação gerado não deve ter sido muito elevado. As correlações genéticas devidas aos efeitos pleiotrópicos dos genes não parecem ter sido significativamente influenciadas pelo desequilíbrio de ligação, o qual não acarretou, portanto, nenhuma alteração devidamente expressiva nas associações entre os caracteres. Um ciclo adicional de recombinação não parece, assim, necessário para dissipar o desequilíbrio provocado pela seleção e pela diminuição do tamanho efetivo populacional, já que os resultados obtidos neste trabalho comprovam que o fenômeno abordado não atingiu magnitude tal que pudesse proporcionar alterações relevantes nas associações entre os caracteres.

Os únicos trabalhos que avaliaram os efeitos da recombinação na seleção recorrente foram realizados em soja (Glycine $\max$ L.), que é uma espécie autógama. Os resultados obtidos mostraram também que gerações adicionais de recombinação não proporcionam vantagens para o melhoramento (Piper \& Fehr, 1987; Guimarães \& Fehr, 1989). Felizmente, os resultados obtidos no presente trabalho também corroboram as considerações teóricas e experimentais destacadas na literatura em outras condições. Assim, a realização de apenas uma geração de recombinação, que tem sido geralmente o procedimento padrão da seleção recorrente, parece ser mais aconselhável do que a realização de múltiplas gerações. Apenas uma geração de recombinação parece ser, portanto, necessária para gerar variabilidade genética suficiente para o ciclo seletivo seguinte. Uma geração a mais de cruzamentos demandaria mais tempo e mais recursos. 
Obviamente, gerações adicionais estenderiam demasiadamente os ciclos da seleção recorrente e não gerariam a variabilidade genética desejada, como também talvez não alterassem as correlações genéticas entre os caracteres. Como normalmente, na seleção, índices, que são funções das covariâncias entre os caracteres, são utilizados, alterações nas correlações genéticas poderiam também afetar de maneira considerável o processo seletivo. O presente trabalho, porém, além de não descrever modificações nas médias populacionais e nas variâncias genéticas dos caracteres estudados, não relata também mudanças significativas no padrão das correlações genéticas verificadas entre tais caracteres. 


\section{CONCLUSÕES}

Nas condições do presente trabalho, isto é, para a população estudada e nos ambientes em que foi avaliada, as conclusões são as seguintes:

1) As médias dos cinco caracteres avaliados - peso de espigas, altura da planta, altura da espiga, posição relativa da espiga e índice de espigas - não apresentaram diferenças significativas com uma e com duas gerações de recombinação tanto para as progênies de meios irmãos como para as progênies de irmãos germanos.

2) As variâncias genéticas dos cinco caracteres avaliados não apresentaram alterações com uma e com duas gerações de recombinação tanto para as progênies de meios irmãos como para as progênies de irmãos germanos.

3) As correlações genéticas entre os pares de caracteres avaliados também não apresentaram alterações significativas entre as duas gerações de recombinação para os dois tipos de progênie avaliados.

4) Recomenda-se, portanto, em programas de seleção recorrente em milho, a utilização de apenas uma geração de recombinação dos genótipos selecionados, já que uma geração adicional de recombinação não proporcionou nenhum benefício significativo. 


\section{REFERÊNCIAS BIBLIOGRÁFICAS}

AGUILAR MORAN, J. F. Avaliação do potencial genético de linhagens e respectivos testadores obtidos de duas populações de milho (Zea mays L.). Piracicaba, 1984. 118 p. Dissertação (Mestrado) - Escola Superior de Agricultura "Luiz de Queiroz", Universidade de São Paulo.

ALTMAN, D. W.; BUSCH, R. H. Random intermating before selection in spring wheat. Crop Science, v. 24, n. 6, p. 1085-1089, 1984.

ANDRADE, J. A. C. Seleção divergente para tamanho do pendão e posição da espiga na população ESALQ-PB 1 de milho (Zea mays L.). Piracicaba, 1988.136 p. Dissertação (Mestrado) - Escola Superior de Agricultura "Luiz de Queiroz", Universidade de São Paulo.

ANDRADE, J. A. C.; MIRANDA FILHO, J. B. Correlações genéticas e fenotípicas envolvendo caracteres da planta e do pendão do milho. Relatório Científico do Departamento de Genética da Escola Superior de Agricultura "Luiz de Queiroz", v. 14, p. 5-10, 1980.

ARAÚJO, P. M. Variabilidade genética em subpopulações de milho (Zea mays L.) obtidas por seleção divergente. Piracicaba, 1992. 153 p. Dissertação (Mestrado) Escola Superior de Agricultura "Luiz de Queiroz", Universidade de São Paulo. 
ARIAS, C. A. A. Componentes de variància e covariància genética relacionados à seleção recorrente intra e interpopulacional no milho (Zea mays L.). Piracicaba, 1995. 139 p. Tese (Doutorado) - Escola Superior de Agricultura "Luiz de Queiroz", Universidade de São Paulo.

AVERY, P. J. The effect of finite population size on models of linked overdominant loci. Genetical Research, v. 31, n. 3, p. 239-254, 1978.

BANZATTO, D. A.; KRONKA, S. N. Experimentação agrícola. Jaboticabal: FUNEP, 1992. cap. 2, p. 23-52: Testes de significância.

BANZATTO, D. A.; KRONKA, S. N. Experimentação agrícola. Jaboticabal: FUNEP, 1992. cap. 8, p. 213-236: Análise de grupos de experimentos.

BARBIN, D. Componentes de variância. Piracicaba: Escola Superior de Agricultura "Luiz de Queiroz" - Departamento de Matemática e Estatística, 1993. 108 p.

BASSOI, M. C. Avaliação de progênies de meios irmãos de milho (Zea mays L.) em função do tipo de endosperma. Piracicaba, 1987. 127 p. Dissertação (Mestrado) Escola Superior de Agricultura "Luiz de Queiroz", Universidade de São Paulo.

BENITEZ TORRES, L. Avaliação de progênies de irmãos germanos obtidas por cruzamentos em cadeia em duas populações de milho (Zea mays L.). Piracicaba, 1986. 102 p. Dissertação (Mestrado) - Escola Superior de Agricultura "Luiz de Queiroz", Universidade de São Paulo.

BETRAN, F. J.; HALLAUER, A. R. Hybrid improvement after reciprocal recurrent selection in BSSS and BSCB1 maize populations. Maydica, v. 41, n. 1, p. 25-33, 1996. 
BIANCO, S. Avaliação do potencial genético de populações de milho (Zea mays L.) braquítico para teor de óleo na semente. Piracicaba, 1984. 98 p. Dissertação (Mestrado) - Escola Superior de Agricultura "Luiz de Queiroz", Universidade de São Paulo.

BIANCO, S.; TOSELlO, G. A.; SOUZA JÚNIOR, C. L. Correlações genéticas e fenotípicas em duas populações de milho (Zea mays L.) braquítico e suas implicações no melhoramento do teor de óleo do grão. Anais da Escola Superior de Agricultura "Luiz de Queiroz", v. 44, n. 1, p. 801-810, 1987.

BIGOTO, C. A. Estudo da população ESALQ-PB 1 de milho (Zea mays L.) em cinco ciclos de seleção recorrente. Piracicaba, 1988. 124 p. Dissertação (Mestrado) Escola Superior de Agricultura "Luiz de Queiroz", Universidade de São Paulo.

BOS, 1. More arguments against intermating $F_{2}$ plants of a self-fertilizing crop. Euphytica, v. 26, n. 1/2, p. 33-46, 1977.

BROWN, A. H. D. Sample sizes required to detect linkage disequilibrium between two or three loci. Theoretical Population Biology, v. 8, n. 2, p. 184-201, 1975.

BULMER, M. G. The effect of selection on genetic variability. American Naturalist, v. 105, n. 943, p. 201-211, 1971.

BULMER, M. G. Linkage disequilibrium and genetic variability. Genetical Research, v. 23, n. 3, p. 281-289, 1974.

BUREN, L. L.; MOCK, J. J.; ANDERSON, I. C. Morphological and physiological traits in maize associated with tolerance to high plant density. Crop Science, v. 14, n. 3, p. 426-429, 1974. 
BURGESS, J. C.; WEST, D. R. Selection for grain yield following selection for ear height in maize. Crop Science, v. 33, n. 4, p. 679-682, 1993.

CAMARGO BUITRAGO, I. Comparação de três processos seletivos para a identificação de linhagens $S_{1}$ superiores em milho (Zea mays L.). Piracicaba, 1996. 148 p. Tese (Doutorado) - Escola Superior de Agricultura "Luiz de Queiroz", Universidade de São Paulo.

CANTON, T. Avaliação de oito ciclos de seleção recorrente na população de milho (Zea mays L.) Suwan DMR. Piracicaba, 1988. 112 p. Dissertação (Mestrado) Escola Superior de Agricultura "Luiz de Queiroz", Universidade de São Paulo.

CAVIEDES CEPEDA, G. M. Seleção recorrente em milho. Piracicaba: Escola Superior de Agricultura "Luiz de Queiroz" - Departamento de Genética, 1995. 42 p.

CHAVES, L. J. Tamanho da parcela para seleção de progênies de milho (Zea mays L.). Piracicaba, 1985. 148 p. Tese (Doutorado) - Escola Superior de Agricultura 'Luiz de Queiroz", Universidade de São Paulo.

CHAVES, L. J.; MIRANDA FILHO, J. B. Plot size for progeny selection in maize (Zea mays L.). Theoretical and Applied Genetics, v. 84, n. 7/8, p. 963-970, 1992.

COCHRAN, W. G.; COX, G. M. Experimental designs. New York: John Wiley \& Sons, 1957. cap. 10, p. 396-438: Lattice designs.

COCHRAN, W. G.; COX, G. M. Experimental designs. New York: John Wiley \& Sons, 1957. cap. 14, p. 545-568: Analysis of the results of a series of experiments. 
COCKERHAM, C. C. Effects of linkage on the covariance between relatives. Genetics, v. 41, n. 1, p. 138-141, 1956.

COMSTOCK, R. E.; ROBINSON, H. F. The components of genetic variance in populations of biparental progenies and their use in estimating the average degree of dominance. Biometrics, v. 4, n. 4, p. 254-266, 1948.

COMSTOCK, R. E.; ROBINSON, H. F. Estimation of average dominance of genes. In: GOWEN, J. W. Heterosis. Ames: Iowa State College Press, 1952. cap. 30, p. 494-516.

COMSTOCK, R. E.; ROBINSON, H. F.; HARVEY, P. H. A breeding procedure designed to make maximum use of both general and specific combining ability. Agronomy Journal, v. 41, n. 8, p. 360-367, 1949.

COVARRUBIAS-PRIETO, J.; HALLAUER, A. R.; LAMKEY, K. R. Intermating $\mathrm{F}_{2}$ populations of maize. Genetika, v. 21, n. 1, p. 111-126, 1989.

CROSSA, J.; GARDNER, C. O. Predicted and realized grain yield responses to full-sib family selection in CIMMYT maize (Zea mays L.) populations. Theoretical and Applied Genetics, v. 77, n. 1, p. 33-38, 1989.

CROW, J. F. Dominance and overdominance. In: GOWEN, J. W. Heterosis. Ames: Iowa State College Press, 1952. cap. 18, p. 282-297.

CROW, J. F. Basic concepts in population, quantitative and evolutionary genetics. New York: W. H. Freeman and Company, 1986. cap. 1, p. 1-28: Genes in populations. 
CUNHA, R. N. V. Potencial genético de populações de milho (Zea mays L.) obtidas de germoplasma exótico. Piracicaba, 1996. 127 p. Dissertação (Mestrado) - Escola Superior de Agricultura "Luiz de Queiroz", Universidade de São Paulo.

DOMANSKI, C. E. Avaliação de dois compostos de milho opaco-2 modificado (Zea mays L.) para o melhoramento interpopulacional. Piracicaba, 1991. $133 \mathrm{p}$. Tese (Doutorado) - Escola Superior de Agricultura "Luiz de Queiroz", Universidade de São Paulo.

DUVICK, D. N. Continuous backcrossing to transfer prolificacy to a single-eared inbred line of maize. Crop Science, v. 14, n. 1, p. 69-71, 1974.

EYHERABIDE, G. H.; HALLAUER, A. R. Reciprocal full-sib recurrent selection in maize: I. Direct and indirect responses. Crop Science, v. 31, n. 4, p. 952-959, 1991a.

EYHERABIDE, G. H.; HALLAUER, A. R. Reciprocal full-sib recurrent selection in maize: II. Contributions of additive, dominance and genetic drift effects. Crop Science, v. 31, n. 6, p. 1442-1448, 1991 b.

FALCONER, D. S. Introduction to quantitative genetics. 3. ed. Harlow: Longman Scientific \& Technical, 1989. 438 p.

FARIAS NETO, A. L. Sexto ciclo de seleção divergente para tamanho do pendão e altura da espiga na população de milho (Zea mays L.) ESALQ-PB 1. Piracicaba, 1995. 108 p. Dissertação (Mestrado) - Escola Superior de Agricultura 'quiz de Queiroz", Universidade de São Paulo. 
FELSENSTEIN, J. Uncorrelated genetic drift of gene frequencies and linkage disequilibrium in some models of linked overdominant polymorphisms. Genetical Research, v. 24, n. 3, p. 281-294, 1974.

FERNANDES, J. S. C. Progressos esperados em linhagens de milho via seleção recomente intra e interpopulacional. Piracicaba, 1990. 235 p. Tese (Doutorado) Escola Superior de Agricultura "Luiz de Queiroz", Universidade de São Paulo.

FISCHER, K. S.; EDMEADES, G. O.; JOHNSON, E. C. Recurrent selection for reduced tassel branch number and reduced leaf area density above the ear in tropical maize populations. Crop Science, v. 27, n. 6, p. 1150-1156, 1987.

GALLAIS, A. Covariances between arbitrary relatives with linkage and epistasis in the case of linkage disequilibrium. Biometrics, v. 30, n. 3, p. 429-446, 1974.

GALLEY, S. J.; CURNOW, R. N. The effects of finite populations size and selection on the correlation between gene frequency changes at two different loci and on the amount of linkage disequilibrium. Theoretical and Applied Genetics, v. 42, n. 7, p. 335-345, 1972.

GARDNER, C. O. Estimates of genetic parameters in cross-fertilizing plants and their inimplications in plant breeding. In: HANSON, W. D.; ROBINSON, H. F. Statistical genetics and plant breeding. Washington: NASNRC, 1963. p. 225252.

GARDNER, C. O.; LONNQUIST, J. H. Linkage and the degree of dominance of genes controlling quantitative characters in maize. Agronomy Journal, v. 51, n. 9, p. 524-528, 1959. 
GARDNER, C. O.; HARVEY, P. H.; COMSTOCK, R. E.; ROBINSON, H. F. Dominance of genes controlling quantitative characters in maize. Agronomy Journal, v. 45, n. 5, p. 186-191, 1953.

GARZA, A. M. Diseños experimentales. Cidade do México: Trillas, 1988. cap. 11, p. 405-459: Diseños de bloques incompletos. Látices.

GERALDI, I. O. Estimação de parâmetros genéticos de caracteres do pendão em milho (Zea mays L.) e perspectivas de melhoramento. Piracicaba, 1977. 103 p. Dissertação (Mestrado) - Escola Superior de Agricultura "Luiz de Queiroz", Universidade de São Paulo.

GERALDI, I. O.; MIRANDA FILHO, J. B.; VENCOVSKY, R. Estimates of genetic parameters for tassel characters in maize (Zea mays L.) and breeding perspectives. Maydica, v. 30, n. 1, p. 1-14, 1985.

GOMES, F. P. Curso de estatística experimental. Piracicaba: Nobel, 1990. cap. 8, p. 126-150: Análise de grupos de experimentos.

GOMES, F. P. Curso de estatística experimental. Piracicaba: Nobel, 1990. cap. 11, p. 206-226: Reticulados quadrados.

GUIMARÃES, E. P.; FEHR, W. R. Alternative strategies of recurrent selection for seed yield of soybean. Euphytica, v. 40, n. 1/2, p. 111-120, 1989.

HALLAUER, A. R. Genetic variability for yield after four cycles of reciprocal recurrent selection in maize. Crop Science, v. 10, n. 5, p. 482-485, 1970

HALLAUER, A. R. Reciprocal full-sib selection in maize. Crop Science, v. 24, n. 4, p. $755-757,1984$. 
HALLAUER, A. R.; EBERHART, S. A. Reciprocal full-sib selection. Crop Science, v. 10, n. 3, p. $315-316,1970$.

HALLAUER, A. R.; MIRANDA FILHO, J. B. Quantitative genetics in maize breeding. 2. ed. Ames: Iowa State University Press, 1988. 468 p.

HAN, GENG-CHEN; HALLAUER, A. R. Estimates of genetic variability in $F_{2}$ maize populations. Journal of the Iowa Academy of Science, v. 96, n. 1, p. 14-19, 1989.

HANSON, W. D. The breakup of initial linkage blocks under selected mating systems. Genetics, v. 44, n. 5, p. 857-868, 1959.

HANSON, W. D.; HAYMAN, B. I. Linkage effects on additive genetic variance among homozygous lines arising from the cross between two homozygous parents. Genetics, v. 48, n. 1, p. 755-766, 1963.

HELMS, T. C.; HALLAUER, A. R.; SMITH, O. S. Genetic drift and selection evaluated from recurrent selection programs in maize. Crop Science, v. 29, n. 3, p. 602-607, 1989a.

HELMS, T. C.; HALLAUER, A. R; SMITH, O. S. Genetic variability estimates in improved and nonimproved "Iowa Stiff Stalk Synthetic" maize populations. Crop Science, v. 29, n. 4, p. 959-962, 1989b.

HILL, W. G. Disequilibrium among several linked neutral genes in finite population. I. Mean changes in disequilibrium. Theoretical Population Biology, v. 5, n. 3, p. 366-392, 1974a. 
HILL, W. G. Disequilibrium among several linked neutral genes in finite population. II. Variances and covariances of disequilibria. Theoretical Population Biology, v. 6, n. 2 , p. $184-198,1974 b$.

HILL, W. G. Linkage disequilibrium among multiple neutral alleles produced by mutation in finite population. Theoretical Population Biology, v. 8, n. 1, p. 117126, 1975.

HILL, W. G. Non-random association of neutral linked genes in finite populations. In: KARLIN, S.; NEVO, E. Population genetics and ecology. New York: Academic Press, 1976. p. 339-376.

HILL, W. G. Correlation of gene frequencies between neutral linked genes in finite populations. Theoretical Population Biology, v. 11, n. 2, p. 239-248, 1977.

HILL, W. G.; ROBERTSON, A. Linkage disequilibrium in finite populations. Theoretical and Applied Genetics, v. 38, n. 5, p. 226-231, 1968.

HULL, F. H. Recurrent selection for specific combining ability in corn. Journal of the American Society of Agronomy, v. 37, p. 134-145, 1945.

HULL, F. H. Recurrent selection and overdominance. In: GOWEN, J. W. Heterosis. Ames: Iowa State College Press, 1952. cap. 28, p. 451-473.

HUMPHREY, A. B.; MATZINGER, D. F.; COCKERHAM, C. C. Effects of random intercrossing in a naturally self-fertilizing species, Nicotiana tabacum L. Crop Science, v. 9, n. 4, p. 495-497, 1969. 
KARLIN, S.; MCGREGOR, J. Rates and probabilities of fixation for two-locus and random mating finite populations without selection. Genetics, v. 58, n. 1, p. 141$159,1968$.

KEERATINIJAKAL, V.; LAMKEY, K. R. Responses to reciprocal recurrent selection in BSSS and BSCB1 maize populations. Crop Science, v. 33, n. 1, p. 73-77, 1993a.

KEERATINIJAKAL, V.; LAMKEY, K. R. Genetic effects associated with reciprocal recurrent selection in BSSS and BSCB1 maize populations. Crop Science, v. 33, n. 1, p. $78-82,1993$ b.

KNAPP, S. J.; STROUP, W. W.; ROSS, W. M. Exact confidence intervals for heritability on a progeny mean basis. Crop Science, v. 25, n. 1, p. 192-194, 1985.

LAMKEY, K. R. Fifty years of recurrent selection in the Iowa Stiff Stalk Synthetic maize population. Maydica, v. 37, n. 1, p. 19-28, 1992.

LAMKEY, K. R.; HALLAUER, A. R. Heritability estimated from recurrent selection experiments in maize. Maydica, v. 32, n. 1, p. 61-78, 1987.

LAMKEY, K. R.; SCHNICKER, B. J.; MELCHINGER, A. E. Epistasis in an elite maize hybrid and choice of generation for inbred line development. Crop Science, v. 35, n. 5 , p. $1272-1281,1995$.

LANDI, P.; FRASCAROLI, E. Effects of intermating on the genetic variability of $F_{2}$ maize populations. Agriculture Mediterranean, v. 120, n. 1, p. 25-30, 1990.

LANDI, P.; FRASCAROLI, E. Responses to four cycles of full-sib family recurrent selection in an $F_{2}$ maize population. Maydica, v. 38, n. 1, p. 31-37, 1993. 
LEGG, P. D.; MATZINGER, D. F.; MANN, T. J. Genetic variation and covariation in a Nicotiana tabacum L. synthetic two generations after synthesis. Crop Science, v. 5, n. 1, p. 30-33, 1965.

LI, C. C. First course in population genetics. Pacific Grove: Boxwood, 1974. cap. 1, p. 1-15: Large random-mating populations.

LI, C. C. First course in population genetics. Pacific Grove: Boxwood, 1974. cap. 10, p. 177-208: Two pairs of genes.

LIMA NETO, F. P. Tamanhos de amostras para estimação de parâmetros genéticos em milho (Zea mays L.). Piracicaba, 1994. 81 p. Dissertação (Mestrado) - Escola Superior de Agricultura "Luiz de Queiroz", Universidade de São Paulo.

LIMA NETO, F. P. Desequilíbrio de ligação. Piracicaba: Escola Superior de Agricultura "Luiz de Queiroz" - Departamento de Genética, 1994. 22 p.

LIMA NETO, F. P. Grau médio de dominância em presença de desequilíbrio de ligação. Piracicaba: Escola Superior de Agricultura 'Luiz de Queiroz" Departamento de Genética, 1995. 19 p.

LITTLER, R. A. Linkage disequilibrium in two-locus finite random mating models without selection or mutation. Theoretical Population Biology, v. 4, n. 2, p. 259275, 1973.

MACKAY, I. J.; GIBSON, J. P. The effect of gametic-phase disequilibrium on the prediction of response to recurrent selection in plants. Theoretical and Applied Genetics, v. 87, n. 1/2, p. 152-160, 1993. 
MAMEDE, F. B. F. Estimação de parâmetros genéticos e fenotípicos em duas populações de milho (Zea mays L.) opaco. Piracicaba, 1991. 183 p. Tese (Doutorado) - Escola Superior de Agricultura "Luiz de Queiroz", Universidade de São Paulo.

MANGELSDORF, A. J. Gene interaction with heterosis. In: GOWEN, J. W. Heterosis. Ames: Iowa State College Press, 1952. cap. 20, p. 320-329.

MARIOTE, D. Avaliação do potencial genético de duas populações de milho (Zea mays L.) e suas implicações no melhoramento do teor de óleo. Piracicaba, 1993. 101 p. Dissertação (Mestrado) - Escola Superior de Agricultura "Luiz de Queiroz", Universidade de São Paulo.

MARQUES, J. R. B. Seleção recorrente com endogamia em duas populações de milho (Zea mays L.). Piracicaba, 1988. 145 p. Dissertação (Mestrado) - Escola Superior de Agricultura "Luiz de Queiroz", Universidade de São Paulo.

MATHER, K.; JNKS, J. L. Biometrical genetics: the study of continuous variation. 3. ed. London: Chapman \& Hall, 1982. 396 p.

MATZINGER, D. F.; WERNSMAN, E. A. Four cycles of mass selection in a synthetic variety of an autogamous species, Nicotiana tabacum L. Crop Science, v. 8, n. 2, p. $239-243,1968$.

MEREDITH JR., W. R.; BRIDGE, R. R. Breakup of linkage blocks in cotton, Gossypium hirsutum L. Crop Science, v. 11, n. 5, p. 695-698, 1971.

METTLER, L. E.; GREGG, T. G. Population genetics and evolution. New Jersey: Prentice-Hall, 1969. cap. 3, p. 29-60: Genes in demes. 
MILLER, P. A.; RAWLINGS, J. O. Breakup of initial linkage blocks through intermating in a cotton breeding population. Crop Science, v. 7, n. 3, p. 199-204, 1967.

MIRANDA FILHO, J. B. Mating schemes to predict gain on heterosis in reciprocal recurrent selection. Revista Brasileira de Genética, v. 5, n. 4, p. 745-760, 1982.

MIRANDA FILHO, J. B.; PATERNIANI, E. Intra and interpopulation genetic parameter estimates and implications in selection. Revista Brasileira de Genética, v. 6, n. 1, p. $15-27,1983$.

MOLL, R. H. Sixteen cycles of recurrent full-sib family selection for grain weight in two maize populations. Crop Science, v. 31, n. 4, p. 959-964, 1991.

MOLL, R. H.; HANSON, W. D. Comparisons of effects of intrapopulation vs. interpopulation selection in maize. Crop Science, v. 24, n. 6, p. 1047-1052, 1984.

MOLL, R. H.; SMITH, O. S. Genetic variances and selection responses in an advanced generation of a hybrid of widely divergent populations of maize. Crop Science, $v$. 21, n. 3, p. 387-391, 1981.

MOLL, R. H.; JACKSON, W. A.; MIKKELSEN, R. L. Recurrent selection for maize grain yield: dry matter and nitrogen accumulation and partitioning changes. Crop Science, v. 34, n. 4, p. 874-881, 1994.

MOLL, R. H.; LINDSEY, M. F.; ROBINSON, H. F. Estimates of genetic variances and level of dominance in maize. Genetics, v. 49, n. 3, p. 411-423, 1964. 
MORAES, M. L. T.; PATIÑO-VALERA, F.; MORI, E. S.; KAGEYAMA, P. Y. Aspectos práticos dos delineamentos em látice. Piracicaba: Escola Superior de Agricultura "Luiz de Queiroz" - Instituto de Pesquisas e Estudos Florestais, 1988. 21 p. (Série técnica, 14).

MORENO-GONZALEZ, J.; DUDLEY, J. W.; LAMBERT, R. J. A design III study of linkage disequilibrium for percent oil in maize. Crop Science, v. 15, n. 6, p. 840$843,1975$.

NASS, L. L. Variabilidade genética de populações semi-exóticas de milho (Zea mays L.). Piracicaba, 1992. 136 p. Tese (Doutorado) - Escola Superior de Agricultura "Luiz de Queiroz", Universidade de São Paulo.

NOGUEIRA, M. C. S. Estatística experimental aplicada à experimentação agronômica. Piracicaba: Escola Superior de Agricultura "Luiz de Queiroz" Departamento de Matemática e Estatística, 1994. cap. 4, p. 47-72: Comparações múltiplas (técnica de comparação de médias).

NOGUEIRA, M. C. S. Estatística experimental aplicada à experimentação agronômica. Piracicaba: Escola Superior de Agricultura "Luiz de Queiroz" Departamento de Matemática e Estatística, 1994. cap. 13, p. 233-245: Grupo de experimentos.

NORDQUIST, P. T.; WEBSTER, O. J.; GARDNER, C. O.; ROSS, W. M. Registration of three sorghum germplasm random mating populations. Crop Science, v. 13, $\mathrm{n}$. 1, p. 132, 1973.

OHTA, T. Effect of initial linkage disequilibrium and epistasis on fixation probability in a small population, with two segregating loci. Theoretical and Applied Genetics, v. 38, n. 6, p. 243-248, 1968. 
OHTA, T.; KIMURA, M. Linkage disequilibrium due to random genetic drift. Genetical Research, v. 13, n. 1, p. 47-55, 1969a.

OHTA, T.; KIMURA, M. Linkage disequilibrium at steady state determined by random genetic drift and recurrent mutation. Genetics, v. 63, n. 1, p. 229-238, 1969 b.

OHTA, T.; KIMURA, M. Development of associative overdominance through linkage disequilibrium in finite populations. Genetical Research, v. 16, n. 2, p. 165-177, 1970.

OHTA, T.; KIMURA, M. Linkage disequilibrium between two segregating nucleotide sites under the steady flux of mutations in a finite population. Genetics, v. 68, n. 3 , p. 571-580, 1971.

PACKER, D. Seleção entre e dentro de famílias de meios irmãos em milho (Zea mays L.) na população ESALQ-VD 2 waxy. Piracicaba, 1991. 88 p. Dissertação (Mestrado) - Escola Superior de Agricultura "Luiz de Queiroz", Universidade de São Paulo.

PANDEY, S.; GARDNER, C. O. Recurrent selection for population, variety and hybrid improvement in tropical maize. Advances in agronomy, v. 48, p. 1-87, 1992.

PANDEY, S.; CEBALlOS, H.; MAGNAVACA, R.; BAHIA FILHO, A. F. C.; DUQUE-VARGAS, J.; VINASCO, L. E. Genetics of tolerance to soil acidity in tropical maize. Crop Science, v. 34, n. 6, p. 1511-1514, 1994.

PATERNIANI, E.; VENCOVSKY, R. Reciprocal recurrent selection in maize (Zea mays L.) based on testcrosses of half-sib families. Maydica, v. 22, n. 3, p. 141$152,1977$. 
PATERNIANI, E.; VENCOVSKY, R. Reciprocal recurrent selection based on half-sib progenies and prolific plants in maize (Zea mays L.). Maydica, v. 23, n. 4, p. 209$219,1978$.

PEDERSON, D. G. Arguments against intermating before selection in a self-fertilizing species. Theoretical and Applied Genetics, v. 45, n. 4, p. 157-162, 1974.

PELLICANO, I. J. Potencial da interpopulação de milho (Zea mays L.) BR-105 x BR106 para o melhoramento genético. Piracicaba, 1990. 139 p. Dissertação (Mestrado) - Escola Superior de Agricultura "Luiz de Queiroz", Universidade de São Paulo.

PINTO, R. M. C. Tamanhos de amostras para seleção recorrente com progênies $S_{1}$ em milho (Zea mays L.). Piracicaba, 1996. 92 p. Dissertação (Mestrado) - Escola Superior de Agricultura “Luiz de Queiroz", Universidade de São Paulo.

PIPER, T. E.; FEHR, W. R. Yield improvement in a soybean population by utilizing alternative strategies of recurrent selection. Crop Science, v. 27, n. 2, p. 172-178, 1987.

REDDEN, R. J.; JENSEN, N. F. Mass selection and mating systems in cereals. Crop Science, v. 14, n. 3, p. 345-350, 1974.

REZENDE, G. D. S. P. Heterose, depressão por endogamia e variabilidade genética associadas à seleção e oscilação genética nas populações de milho BR-105 e BR106. Piracicaba, 1997. 112 p. Tese (Doutorado) - Escola Superior de Agricultura "Luiz de Queiroz", Universidade de São Paulo. 
ROBINSON, H. F.; COMSTOCK, R. E.; HARVEY, P. H. Estimates of heritability and the degree of dominance in corn. Agronomy Journal, v. 41, n. 8, p. 353-359, 1949.

ROBINSON, H. F.; COMSTOCK, R. E.; HARVEY, P. H. Genetic variances in open pollinated varietes of corn. Genetics, v. 40, n. 1, p. 45-60, 1955.

ROBINSON, H. F.; COCKERHAM, C. C.; MOLL, R. H. Studies on estimation of dominance variance and effects of linkage bias. In: KEMPTHORNE, $\mathrm{O}$. Biometrical genetics. New York: Pergamon Press, 1960. p. 171-177.

RODRIGUEZ, O. A.; HALLAUER, A. R. Effects of recurrent selection in corn populations. Crop Science, v. 28, n. 5, p. 796-800, 1988.

RUSSELL, W. A. Comparison of the hybrid performance of maize inbred lines developed from the original and improved cycles of BSSS. Maydica, v. 30, n. 7, p. 407-419, 1985.

SAMPAIO, N. F. Propriedades genéticas e potencial para o melhoramento dos compostos de milho (Zea mays L.) ESALQ-PB 4 e ESALQ-PB 5. Piracicaba, 1986. 105 p. Dissertação (Mestrado) - Escola Superior de Agricultura "Luiz de Queiroz", Universidade de São Paulo.

SANTOS, M. X. Estudo do potencial genético de duas raças brasileiras de milho (Zea mays L.) para fins de melhoramento. Piracicaba, 1985. $186 \mathrm{p}$. Tese (Doutorado) Escola Superior de Agricultura “Luiz de Queiroz", Universidade de São Paulo.

SANTOS, M. X.; MIRANDA FILHO, J. B. Genetic potencial of two brazilian races of maize (Zea mays L.) for breeding purposes. Journal of Genetics and Breeding, $\mathrm{v}$. 46, n. 1, p. $83-90,1992$. 
SANTOS, M. X.; NASPOLINI FILHO, V. Estimativas de parâmetros genéticos em três ciclos de seleção entre e dentro de famílias de meios irmãos no milho (Zea mays L.) Dentado Composto Nordeste. Revista Brasileira de Genética, v. 9, n. 2, p. $307-319,1986 \mathrm{a}$.

SANTOS, M. X; NASPOLINI FILHO, V. Estimativas de parâmetros genéticos para peso de espigas na população de milho Flint Composto Nordeste. Pesquisa Agropecuária Brasileira, v. 21, n. 7, p. 739-746, 1986 b.

SCHNELL, F. W. The covariance between relatives in the presence of linkage. In: HANSON, W. D.; ROBINSON, H. F. Statistical genetics and plant breeding. Washington: NASNRC, 1963. p. 468-483.

SCHNICKER, B. J.; LAMKEY, K. R. Interpopulation genetic variance after reciprocal recurrent selection in BSSS and BSCB1 maize populations. Crop Science, v. 33, n. 1, p. 90-95, 1993

SILVA, S. O. Estimativas de parâmetros genéticos em populações de milho braquítico, pelo delineamento I, de Comstock e Robinson. Piracicaba, 1990. 138 p. Tese (Doutorado) - Escola Superior de Agricultura "Luiz de Queiroz", Universidade de São Paulo.

SMITH, O. S. A model for evaluating progress from recurrent selection. Crop Science, v. 19, n. 2, p. 223-226, 1979a.

SMITH, O. S. Application of a modified diallel analysis to evaluate recurrent selection for grain yield in maize. Crop Science, v. 19, n. 6, p. 819-822, 1979 b.

SMITH, O. S. Evaluation of recurrent selection in BSSS, BSCB1 and BS13 maize populations. Crop Science, v. 23, n. 1, p. 35-40, 1983. 
SNEDECOR, G. W.; COCHRAN, W. G. Statistical methods. 6. ed. Ames: The Iowa State University Press, 1967. 593 p.

SOARES FILHO, W. S. Características fenotípicas e genéticas das populações de milho (Zea mays L.) braquítico Piranão-VD-2B e Piranão-VF-1B. Piracicaba, 1987. 185 p. Tese (Doutorado) - Escola Superior de Agricultura "Luiz de Queiroz", Universidade de São Paulo.

SOKAL, R. R.; ROHLF, F. J. Biometry: the principles and practice of statistics in biological research. New York: W. H. Freeman and Company, 1995. cap. 8, p. 179-206: Introduction to the analysis of variance.

SOKAL, R R.; ROHLF, F. J. Biometry: the principles and practice of statistics in biological research. New York: W. H. Freeman and Company, 1995. cap. 13, p. 392-450: Assumptions of analysis of variance.

SOUZA JÚNIOR, C. L. Variabilidade genética em milho (Zea mays L.) e relações com a seleção recorrente intra e interpopulacional. Piracicaba, 1983. 148 p. Tese (Doutorado) - Escola Superior de Agricultura "Luiz de Queiroz", Universidade de São Paulo.

SOUZA JÚNIOR, C. L. Procedures for estimating expected genetic progress in inbred lines via recurrent intrapopulation selection. Revista Brasileira de Genética, v. 8, n. 2, p. 329-342, 1985.

SOUZA JÚNIOR, C. L. Reciprocal recurrent selection with half-sib progenies obtained alternately from non-inbred $\left(\mathrm{S}_{0}\right)$ and inbred $\left(\mathrm{S}_{1}\right)$ plants in maize (Zea mays $\mathrm{L}$.). Maydica, v. 32, n. 1, p. 19-31, 1987. 
SOUZA JÚNIOR, C. L. Componentes da variância genética e suas implicações no melhoramento vegetal. Piracicaba: FEALQ, 1989. $134 \mathrm{p}$.

SOUZA JÚNIOR, C. L. Comparisons of intra-, interpopulation and modified recurrent selection methods. Revista Brasileira de Genética, v. 16, n. 1, p. 91-105, 1993.

SOUZA JÚNIOR, C. L. Seleção recorrente e desenvolvimento de híbridos. Piracicaba: Escola Superior de Agricultura "Luiz de Queiroz" - Departamento de Genética, 1997. $22 \mathrm{p}$.

SOUZA JÚNIOR, C. L.; MIRANDA FILHO, J. B. Alterações na heterose via seleção intra e interpopulacional. Pesquisa Agropecuária Brasileira, v. 20, n. 10, p. 1197-1201, 1985.

SOUZA JÚNIOR, C. L.; MIRANDA FILHO, J. B. Genetic variability in two maize (Zea mays L.) populations and its relationship with intra and interpopulation recurrent selection. Revista Brasileira de Genética, v. 12, n. 2, p. 271-285, 1989.

SOUZA JÚNIOR, C. L.; GERALDI, I. O.; ZINSLY, J. R. Estimativas de parâmetros genéticos e fenotípicos de alguns caracteres na população de milho (Zea mays $\mathrm{L}$.) Suwan. Relatório Científico do Departamento de Genética da Escola Superior de Agricultura "Luiz de Queiroz", v. 14, p. 139-145, 1980a.

SOUZA JÚNIOR, C. L.; GERALDI, I. O.; ZINSLY, J. R. Correlações genéticas e fenotípicas entre seis caracteres da população de milho (Zea mays L.) Suwan. Relatório Científico do Departamento de Genética da Escola Superior de Agricultura "Luiz de Queiroz", v. 14, p. 146-152, 1980b 
SOUZA JÚNIOR, C. L.; SANTOS, M. X.; MAGNAVACA, R.; GAMA, E. E. G. Estimativas de parâmetros genéticos na interpopulação de milho BR-105 x BR-106 e suas implicações no melhoramento. Pesquisa Agropecuária Brasileira, v. 28, $\mathrm{n}$. 4, p. 473-479, 1993.

STEEL, R. G. D.; TORRIE, J. H. Principles and procedures of statistics. New York: McGraw-Hill Book Company, 1980. cap. 5, p. 86-121: Comparisons involving two sample means.

STEEL, R. G. D.; TORRIE, J. H. Principles and procedures of statistics. New York: McGraw-Hill Book Company, 1980. cap. 8, p. 172-194: Multiple comparisons.

STOJSIN, D.; KANNENBERG, L. W. Genetic changes associated with different methods of recurrent selection in five maize populations: I. Directly selected traits. Crop Science, v. 34, n. 6, p. 1466-1472, 1994a.

STOJSIN, D.; KANNENBERG, L. W. Genetic changes associated with different methods of recurrent selection in five maize populations: II. Indirectly selected traits. Crop Science, v. 34, n. 6, p. 1473-1479, 1994b.

STROMBERG, L. D.; COMPTON, W. A. Ten cycles of full-sib selection in maize. Crop Science, v. 29, n. 5, p. 1170-1172, 1989.

SVED, J. A. The stability of linked systems of loci with a small population size. Genetics, v. 59, n. 4, p. 543-563, 1968.

SVED, J. A. Linkage disequilibrium and homozygosity of chromosome segments in finite populations. Theoretical Population Biology, v. 2, n. 2, p. 125-141, 1971. 
TAKEDA, C. Estimativas dos efeitos da seleção recorrente intra e interpopulacional em linhagens de milho (Zea mays L.). Piracicaba, 1997. 133 p. Tese (Doutorado) Escola Superior de Agricultura "Luiz de Queiroz", Universidade de São Paulo.

TANNER, A. H.; SMTTH, O. S. Comparison of half-sib and $\mathrm{S}_{1}$ recurrent selection in the Krug Yellow Dent maize populations. Crop Science, v. 27, n. 3, p. 509-513, 1987.

TERASAWA JÚNIOR, F. Seleção recorrente com endogamia em duas populações de milho: avaliação quantitativa e perspectivas para seleção de híbridos. Piracicaba, 1993. 169 p. Dissertação (Mestrado) - Escola Superior de Agricultura "Luiz de Queiroz", Universidade de São Paulo.

TOSELLO, G. A.; GERALDI, I. O. Estimativas de parâmetros genéticos e fenotípicos para caracteres da planta e da qualidade do grão na população de milho ESALQVD Opaco. Relatório Científico do Departamento de Genética da Escola Superior de Agricultura "Luiz de Queiroz", v. 14, p. 183-189, 1980a.

TOSELLO, G. A.; GERALDI, I. O. Correlações genéticas e fenotípicas envolvendo caracteres da planta e da qualidade do grão na população ESALQ-VD Opaco de milho. Relatório Científico do Departamento de Genética da Escola Superior de Agricultura "Luiz de Queiroz", v. 14, p. 190-193, 1980 b.

TOSELLO, G. A.; SOUZA JÚNIOR, C. L.; GERALDI, I. O. Estimativas de parâmetros genéticos de caracteres da planta e da qualidade do grão em uma população de milho opaco (Zea moxys L.). Anais da Escola Superior de Agricultura "Luiz de Queiroz", v. 44, n. 1, p. 627-642, 1987. 
TRAGESSER, S. L.; YOUNGQUIST, W. C.; SMITH, O. S.; COMPTON, W. A. Drift vs. selection effects from five recurrent selection programs in maize. Maydica, $v$. 34, n. 1, p. 23-32, 1989.

VALOIS, A. C. C. Eficiência comparativa de quatro métodos de seleção em uma população melhorada de milho (Zea mays L.). Piracicaba, 1982. 119 p. Tese (Doutorado) - Escola Superior de Agricultura "Luiz de Queiroz", Universidade de São Paulo.

VENCOVSKY, R.; BARRIGA, P. Genética biométrica no fitomelhoramento. Ribeirão Preto: Revista Brasileira de Genética, 1992. 486 p.

VERMA, M. M.; KOCHHAR, S.; KAPOOR, W. R. The assessment of biparental approach in a wheat cross. Zeitschrift für Pflanzenzüchtung, v. 82, n. 2, p. 174$181,1979$.

WALTERS, S. P.; RUSSELL, W. A; LAMKEY, K. R. Performance and genetic variance among $S_{1}$ lines and testcrosses of Iowa Stiff Stalk Synthetic maize. Crop Science, v. 31, n. 1, p. 76-80, 1991a.

WALTERS, S. P.; RUSSELL, W. A; LAMKEY, K. R.; WHITE, P. R. Performance and inbreeding depression between a synthetic and three improved populations of maize. Crop Science, v. 31, n. 1, p. 80-83, 1991 b.

WEIR, B. S.; COCKERHAM, C. C.; REYNOLDS, J. The effects of linkage and linkage disequilibrium on the covariances of noninbred relatives. Heredity, v. 45, n. 3, p. 351-359, 1980.

YAMAZAKI, T. The effects of overdominance on linkage in a multilocus system. Genetics, v. 86, n. 1, p. 227-236, 1977. 
YUNUS, M.; PARODA, R. S. Impact of biparental mating on correlation coefficients in bread wheat. Theoretical and Applied Genetics, v. 62, n. 4, p. 337-343, 1982.

ZANETTE, V. A. Avaliação da produtividade de cultivares de milho (Zea mays L.) braquítico. Piracicaba, 1985. 119 p. Tese (Doutorado) - Escola Superior de Agricultura "Luiz de Queiroz", Universidade de São Paulo.

ZANOTTO, M. D. Variabilidade genética e endogamia em duas populações de milho (Zea mays L.) contrastantes para teor de óleo. Piracicaba, 1986. 62 p. Dissertação (Mestrado) - Escola Superior de Agricultura "Luiz de Queiroz", Universidade de São Paulo.

ZAR, J. H. Biostatistical analysis. New Jersey: Prentice Hall, 1984. cap. 19, p. 306327: Simple linear correlation.

ZIMBACK, L. Estimação de parâmetros genéticos e fenotípicos em uma variedade de milho dentado braquítico opaco (Zea mays L.). Piracicaba, 1985. 169 p. Dissertação (Mestrado) - Escola Superior de Agricultura "Luiz de Queiroz", Universidade de São Paulo. 
TABELAS 


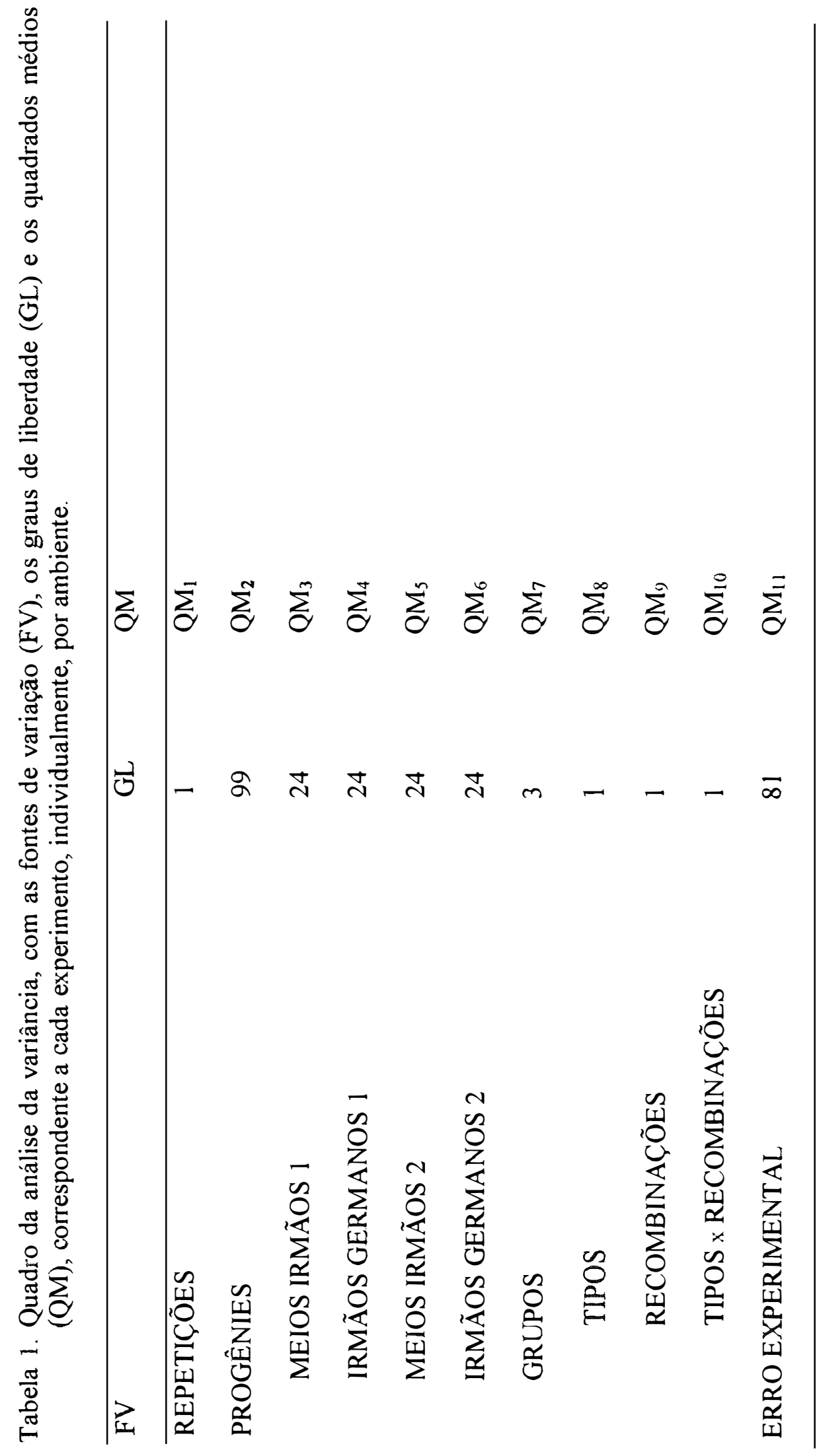




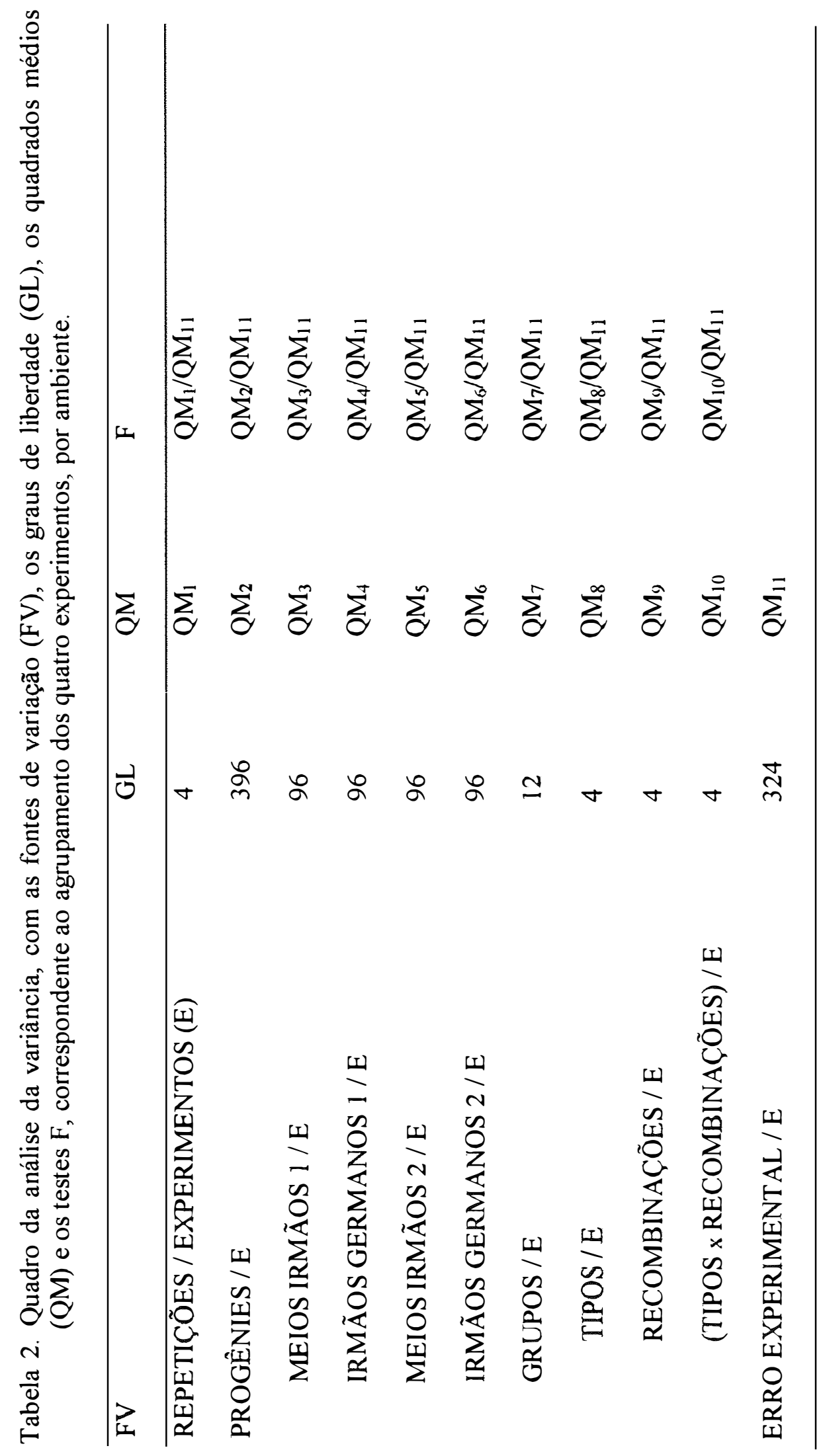




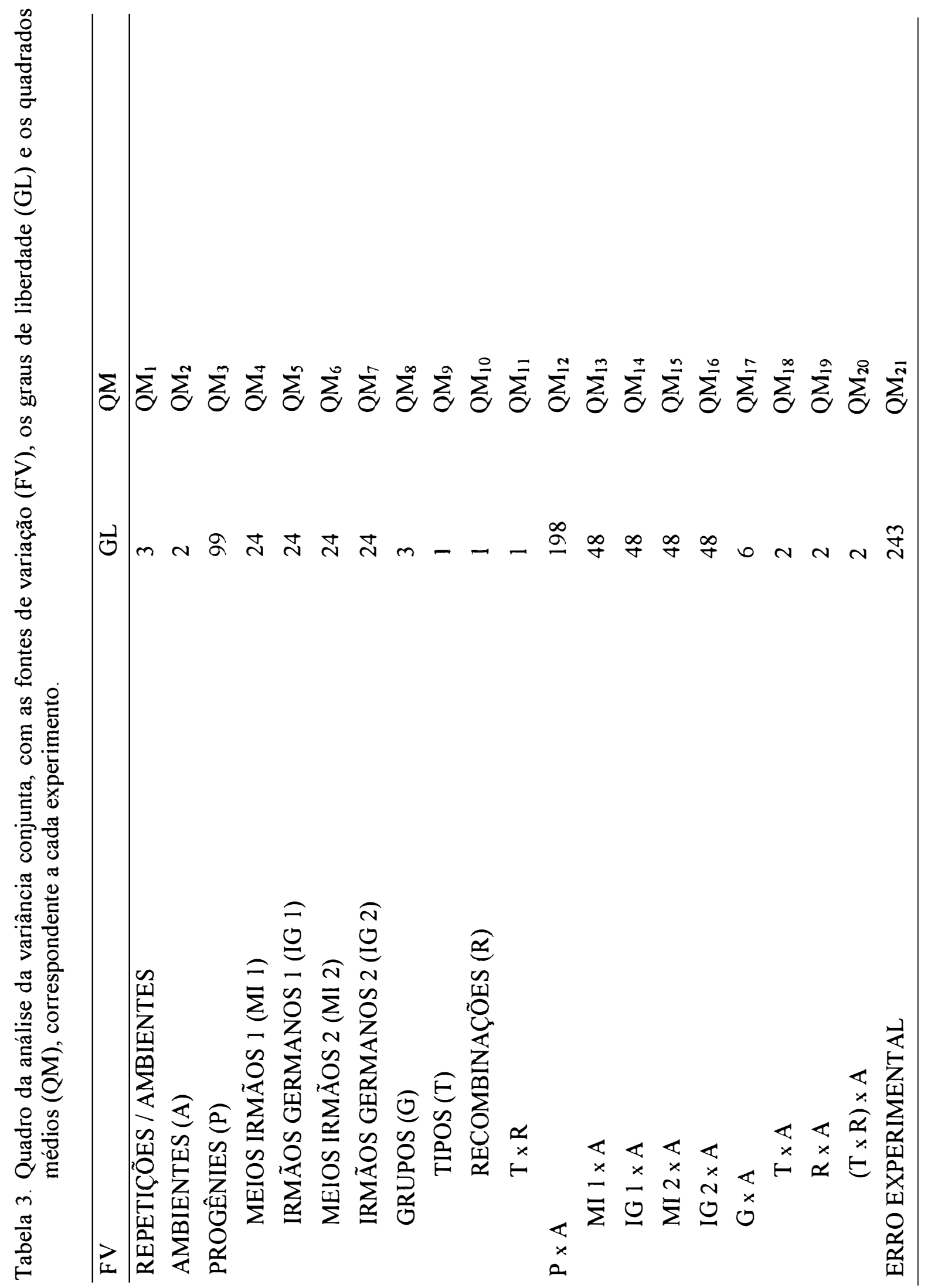




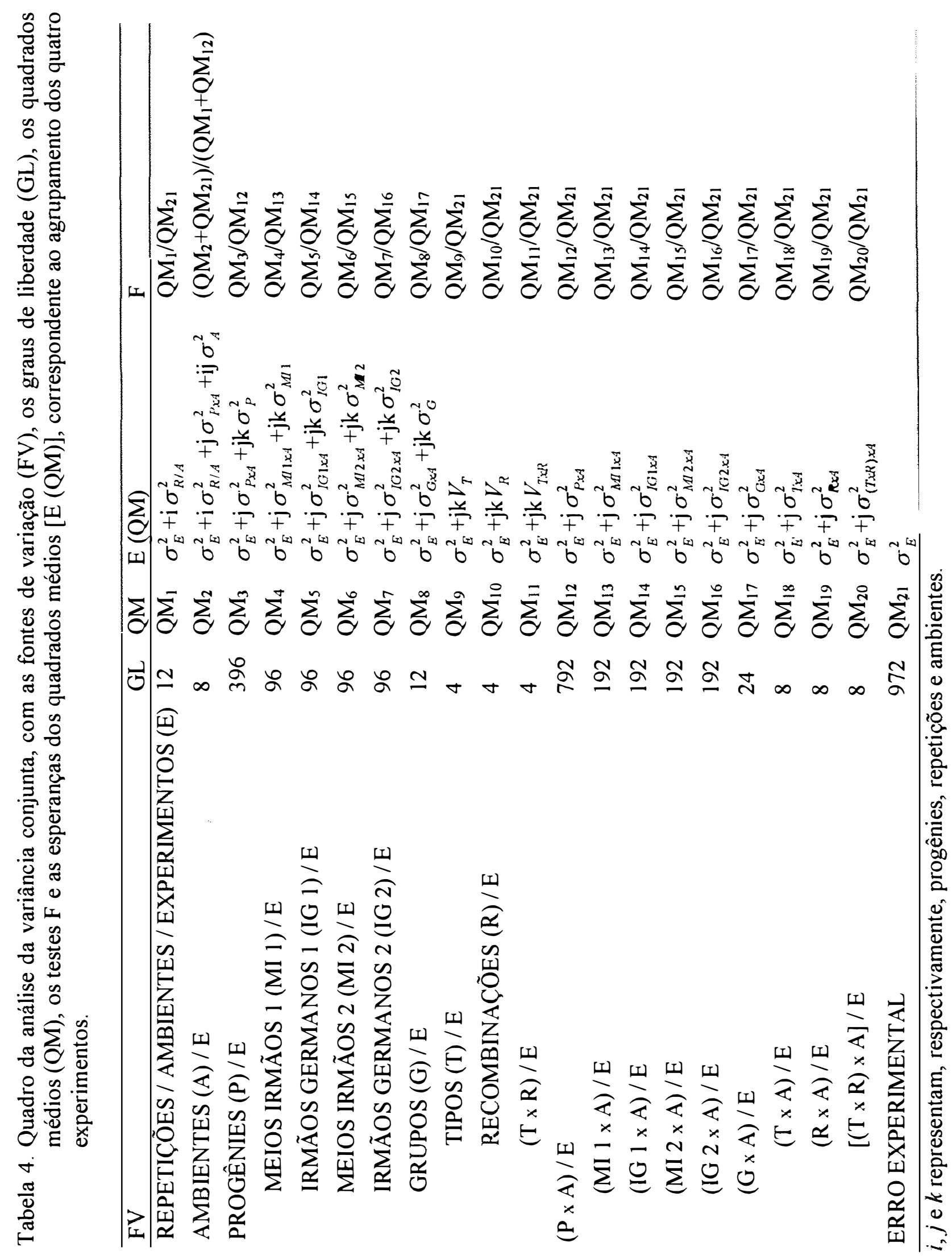


Tabela 5. Valores das diversas médias populacionais (geral, progênies de meios irmãos da $1^{\underline{a}}$ recombinação, progênies de meios irmãos da $2^{\underline{a}}$ recombinação, progênies de irmãos germanos da $1^{\mathfrak{a}}$ recombinação, progênies de irmãos germanos da $2^{2}$ recombinação, progênies de meios irmãos dos dois ciclos de recombinação, progênies de irmãos germanos dos dois ciclos de recombinação, progênies da $1^{\underline{a}}$ recombinação e progênies da $2^{\underline{a}}$ recombinação) e das respectivas diferenças mínimas significativas $(\Delta)$, ao nível de $5 \%$ de significância, para o caráter peso de espigas (PE), analisado em (g/planta), referentes às análises agrupadas, por ambiente.

\section{AMBIENTES}

\begin{tabular}{|c|c|c|c|}
\hline \multirow[b]{2}{*}{ MÉDIAS } & \multirow[b]{2}{*}{1} & \multirow[b]{2}{*}{2} & \multirow[b]{2}{*}{3} \\
\hline & & & \\
\hline PROGENIES DE MEIOS IRMÃOS 1 & 157,79 & 137,52 & 163,48 \\
\hline PROGÊNIES DE MEIOS IRMÃOS 2 & 155,61 & 136,05 & 161,12 \\
\hline PROGÊNIES DE IRMÃOS GERMANOS 1 & 158,81 & 141,76 & 163,34 \\
\hline PROGÊNIES DE IRMÃOS GERMANOS 2 & 153,34 & 134,77 & 155,55 \\
\hline DIFERENÇA MINIMA SIGNIFICATIVA & $\Delta=8,68$ & $\Delta=14,27$ & $\Delta=12,41$ \\
\hline PROGENIES DE MEIOS IRMÃOS & 156,70 & 136,78 & 162,30 \\
\hline PROGÊNIES DE IRMÃOS GERMANOS & 156,07 & 138,26 & 159,44 \\
\hline PROGÊNIES DO CICLO 1 & 158,30 & 139,64 & 163,41 \\
\hline PROGÊNIES DO CICLO 2 & 154,47 & 135,41 & 158,33 \\
\hline DIFERENÇA MINIMA SIGNIFICATIVA & $\Delta=6,14$ & $\Delta=10,09$ & $\Delta=8,77$ \\
\hline GERAL & 156,40 & 137,52 & 160,87 \\
\hline
\end{tabular}


Tabela 6. Valores das diversas médias populacionais (geral, progênies de meios irmãos da $1^{\underline{a}}$ recombinação, progênies de meios irmãos da $2^{\underline{a}}$ recombinação, progênies de irmãos germanos da $1^{\underline{a}}$ recombinação, progênies de irmãos germanos da $2^{\text {a }}$ recombinação, progênies de meios irmãos dos dois ciclos de recombinação, progênies de irmãos germanos dos dois ciclos de recombinação, progênies da $1^{\underline{a}}$ recombinação e progênies da $2^{\underline{a}}$ recombinação) e das respectivas diferenças mínimas significativas $(\Delta)$, ao nivel de $5 \%$ de significância, para o caráter altura da planta (AP), analisado em (cm/planta), referentes às análises agrupadas, por ambiente.

\section{AMBIENTES}

\begin{tabular}{lccc} 
MÉDIAS & 1 & 2 & 3 \\
\cline { 2 - 4 } & & 213,29 & 229,78 \\
PROGĖNIES DE MEIOS IRMÃOS 1 & 226,17 & 210,29 & 234,45 \\
PROGÊNIES DE MEIOS IRMÃOS 2 & 228,43 & 212,55 & 233,85 \\
PROGÊNIES DE IRMÃOS GERMANOS 1 & 225,46 & 210,76 & 231,96 \\
PROGÊNIES DE IRMÃOS GERMANOS 2 & & & \\
\hline DIFERENÇA MINIMA SIGNIFICATIVA & $\Delta=6,28$ & $\Delta=6,54$ & $\Delta=7,83$ \\
\hline PROGENIES DE MEIOS IRMÃOS & 227,43 & 211,79 & 232,11 \\
PROGÊNIES DE IRMÃOS GERMANOS & 226,95 & 211,66 & 232,90 \\
PROGÊNIES DO CICLO 1 & 228,56 & 212,92 & 231,81 \\
PROGÊNIES DO CICLO 2 & 225,82 & 210,53 & 233,20 \\
\hline DIFERENÇA MINIMA SIGNIFICATIVA & $\Delta=4,44$ & $\Delta=4,62$ & $\Delta=5,54$ \\
\hline GERAL & & 211,73 & 232,51 \\
\hline
\end{tabular}


Tabela 7. Valores das diversas médias populacionais (geral, progênies de meios irmãos da $1^{\underline{a}}$ recombinação, progênies de meios irmãos da $2^{\underline{a}}$ recombinação, progênies de irmãos germanos da $1^{\text {ạ }}$ recombinação, progênies de irmãos germanos da $2^{\underline{a}}$ recombinação, progênies de meios irmãos dos dois ciclos de recombinação, progênies de irmãos germanos dos dois ciclos de recombinação, progênies da $1^{\underline{a}}$ recombinação e progênies da $2^{\underline{a}}$ recombinação) e das respectivas diferenças mínimas significativas $(\Delta)$, ao nível de $5 \%$ de significância, para o caráter altura da espiga $(\mathrm{AE})$, analisado em (cm/planta), referentes às análises agrupadas, por ambiente.

\begin{tabular}{|c|c|c|c|}
\hline \multirow[b]{2}{*}{ MÉDIAS } & \multicolumn{3}{|c|}{ AMBIENTES } \\
\hline & 1 & 2 & 3 \\
\hline PROGËNIES DE MEIOS IRMÃOS 1 & 124,78 & 108,23 & 131,32 \\
\hline PROGÊNIES DE MEIOS IRMÃOS 2 & 122,99 & 103,85 & 132,63 \\
\hline PROGÊNIES DE IRMÃOS GERMANOS 1 & 124,94 & 106,64 & 134,48 \\
\hline PROGÊNIES DE IRMÃOS GERMANOS 2 & 123,15 & 105,19 & 131,27 \\
\hline DIFERENÇA MINIMA SIGNIFICATIVA & $\Delta=3,60$ & $\Delta=4,53$ & $\Delta=6,01$ \\
\hline PROGĖNIES DE MEIOS IRMÃOS & 123,89 & 106,04 & 131,97 \\
\hline PROGÊNIES DE IRMÃOS GERMANOS & 124,05 & 105,91 & 132,87 \\
\hline PROGÊNIES DO CICLO 1 & 124,86 & 107,44 & 132,90 \\
\hline PROGÊNIES DO CICLO 2 & 123,07 & 104,52 & 131,95 \\
\hline DIFERENÇA MINIMA SIGNIFICATIVA & $\Delta=2,55$ & $\Delta=3,20$ & $\Delta=4,25$ \\
\hline GERAL & 123,97 & 105,98 & 132,43 \\
\hline
\end{tabular}


Tabela 8. Valores das diversas médias populacionais (geral, progênies de meios irmãos da $1^{\underline{a}}$ recombinação, progênies de meios irmãos da $2^{\underline{a}}$ recombinação, progênies de irmãos germanos da $1^{\underline{a}}$ recombinação, progênies de irmãos germanos da $2^{\underline{a}}$ recombinação, progênies de meios irmãos dos dois ciclos de recombinação, progênies de irmãos germanos dos dois ciclos de recombinação, progênies da $1^{\underline{a}}$ recombinação e progênies da $2^{\underline{a}}$ recombinação) e das respectivas diferenças mínimas significativas $(\Delta)$, ao nível de $5 \%$ de significância, para o caráter posição relativa da espiga (PR), caráter adimensional, referentes às análises agrupadas, por ambiente.

\section{AMBIENTES}

\begin{tabular}{|c|c|c|c|}
\hline \multirow[b]{2}{*}{ MÉDIAS } & \multirow[b]{2}{*}{1} & \multirow[b]{2}{*}{2} & \multirow[b]{2}{*}{3} \\
\hline & & & \\
\hline PROGÊNIES DE MEIOS IRMÃOS 1 & 0,55 & 0,51 & 0,57 \\
\hline PROGÊNIES DE MEIOS IRMÃOS 2 & 0,54 & 0,49 & 0,56 \\
\hline PROGÊNIES DE IRMÃOS GERMANOS 1 & 0,55 & 0,50 & 0,57 \\
\hline PROGÊNIES DE IRMÃOS GERMANOS 2 & 0,55 & 0,50 & 0,57 \\
\hline $\begin{array}{l}\text { DIFERENÇA MÍNIMA SIGNIFICATIVA } \\
\text { (valor multiplicado por } 10^{4} \text { ) }\end{array}$ & $\Delta=95,76$ & $\Delta=136,16$ & $\Delta=162,25$ \\
\hline PROGËNIES DE MEIOS IRMÃOS & 0,54 & 0,50 & 0,57 \\
\hline PROGÊNIES DE IRMÃOS GERMANOS & 0,55 & 0,50 & 0,57 \\
\hline PROGÊNIES DO CICLO 1 & 0,55 & 0,51 & 0,57 \\
\hline PROGÊNIES DO CICLO 2 & 0,55 & 0,50 & 0,57 \\
\hline $\begin{array}{l}\text { DIFERENÇA MINIMA SIGNIFICATIVA } \\
\left(\text { valor multiplicado por } 10^{4}\right)\end{array}$ & $\Delta=67,70$ & $\Delta=96,26$ & $\Delta=114,71$ \\
\hline GERAL & 0,55 & 0,50 & 0,57 \\
\hline
\end{tabular}


Tabela 9. Valores das diversas médias populacionais (geral, progênies de meios irmãos da $1^{\underline{a}}$ recombinação, progênies de meios irmãos da $2^{\underline{a}}$ recombinação, progênies de irmãos germanos da $1^{\underline{a}}$ recombinação, progênies de irmãos germanos da $2^{2}$ recombinação, progênies de meios irmãos dos dois ciclos de recombinação, progênies de irmãos germanos dos dois ciclos de recombinação, progênies da $1^{\underline{a}}$ recombinação e progênies da $2^{\underline{a}}$ recombinação) e das respectivas diferenças mínimas significativas $(\Delta)$, ao nível de $5 \%$ de significância, para o caráter indice de espigas (IE), caráter adimensional, referentes às análises agrupadas, por ambiente.

\section{AMBIENTES}

\begin{tabular}{|c|c|c|c|}
\hline MÉDIAS & 1 & 2 & 3 \\
\hline PROGÉNIES DE MEIOS IRMÃOS 1 & 1,10 & 1,03 & 1,07 \\
\hline PROGÊNIES DE MEIOS IRMÃOS 2 & 1,09 & 1,05 & 1,05 \\
\hline PROGÊNIES DE IRMÃOS GERMANOS 1 & 1,11 & 1,06 & 1,04 \\
\hline PROGÊNIES DE IRMÃOS GERMANOS 2 & 1,11 & 1,03 & 1,05 \\
\hline $\begin{array}{l}\text { DIFERENÇA MINIMA SIGNIFICATIVA } \\
\text { (valor multiplicado por } 10^{2} \text { ) }\end{array}$ & $\Delta=7,20$ & $\Delta=10,49$ & $\Delta=8,08$ \\
\hline PROGÊNIES DE MEIOS IRMÃOS & 1,10 & 1,04 & 1,06 \\
\hline PROGÊNIES DE IRMÃOS GERMANOS & 1,11 & 1,05 & 1,04 \\
\hline PROGÊNIES DO CICLO 1 & 1,11 & 1,05 & 1,05 \\
\hline PROGÊNIES DO CICLO 2 & 1,10 & 1,04 & 1,05 \\
\hline $\begin{array}{l}\text { DIFERENÇA MINIMA SIGNIFICATIVA } \\
\text { (valor multiplicado por } 10^{2} \text { ) }\end{array}$ & $\Delta=5,09$ & $\Delta=7,42$ & $\Delta=5,71$ \\
\hline GERAL & 1,10 & 1,04 & 1,05 \\
\hline
\end{tabular}


Tabela 10. Análises agrupadas da variância, por ambiente, para o caráter peso de espigas $(\mathrm{PE})$, com as fontes de variação (FV), os quadrados médios (QM), em (g/planta $)^{2}$, os testes $\mathrm{F}$ de significância e os coeficientes de variação experimental $\left(\mathrm{CV}_{\mathrm{e}}\right)$, expressos em porcentagem.

\begin{tabular}{|c|c|c|c|}
\hline \multirow[b]{3}{*}{ FV } & \multicolumn{3}{|c|}{ AMBIENTES } \\
\hline & 1 & 2 & 3 \\
\hline & QM & QM & QM \\
\hline REPETIÇŌES & $1779,11^{* *}$ & $4113,62^{* *}$ & $842,6 \operatorname{lns}$ \\
\hline PROGÊNIES & $610,03 * *$ & $1160,68 * *$ & $1046,06^{* *}$ \\
\hline MEIOS IRMÃOS 1 & $575,01^{* *}$ & $862,56 \mathrm{~ns}$ & $1024,86^{* *}$ \\
\hline IRMÃOS GERMANOS 1 & $700,67 * *$ & $1330,29 * *$ & $1180,19 * *$ \\
\hline MEIOS IRMÃOS 2 & $489,67 * *$ & $1073,59 *$ & $942,59 * *$ \\
\hline IRMÃOS GERMANOS 2 & $661,89 * *$ & $1367,34^{* *}$ & $963,74 * *$ \\
\hline GRUPOS & $712,93 * *$ & $1232,33 \mathrm{~ns}$ & $1628,95^{* *}$ \\
\hline TIPOS (T) & $447,86 \mathrm{~ns}$ & $1554,45 \mathrm{~ns}$ & $1234,74 \mathrm{~ns}$ \\
\hline RECOMBINAÇÕES (R) & $1327,91^{* *}$ & $1171,4 \operatorname{lns}$ & $2620,67 * *$ \\
\hline $\mathrm{T} \times \mathrm{R}$ & $363,0 \operatorname{lns}$ & $971,13 \mathrm{~ns}$ & $1031,45 \mathrm{~ns}$ \\
\hline ERRO EXPERIMENTAL & 304,75 & 824,23 & 622,76 \\
\hline $\mathrm{CV}_{\mathrm{e}}(\%)$ & 11,16 & 20,88 & 15,51 \\
\hline \multicolumn{4}{|c|}{ *: significativo ao nivel de $5 \%$ de probabilidade $(\mathrm{P} \leq 5 \%)$} \\
\hline **: significativo ao nível de $1 \% \mathrm{~d}$ & oabilidade & $\%)$ & \\
\hline não significativo. & & & \\
\hline
\end{tabular}


Tabela 11. Análises agrupadas da variância, por ambiente, para o caráter altura da planta $(\mathrm{AP})$, com as fontes de variação (FV), os quadrados médios (QM), em $(\mathrm{cm} / \text { planta })^{2}$, os testes $\mathrm{F}$ de significância e os coeficientes de variação experimental $\left(\mathrm{CV}_{\mathrm{e}}\right)$, expressos em porcentagem.

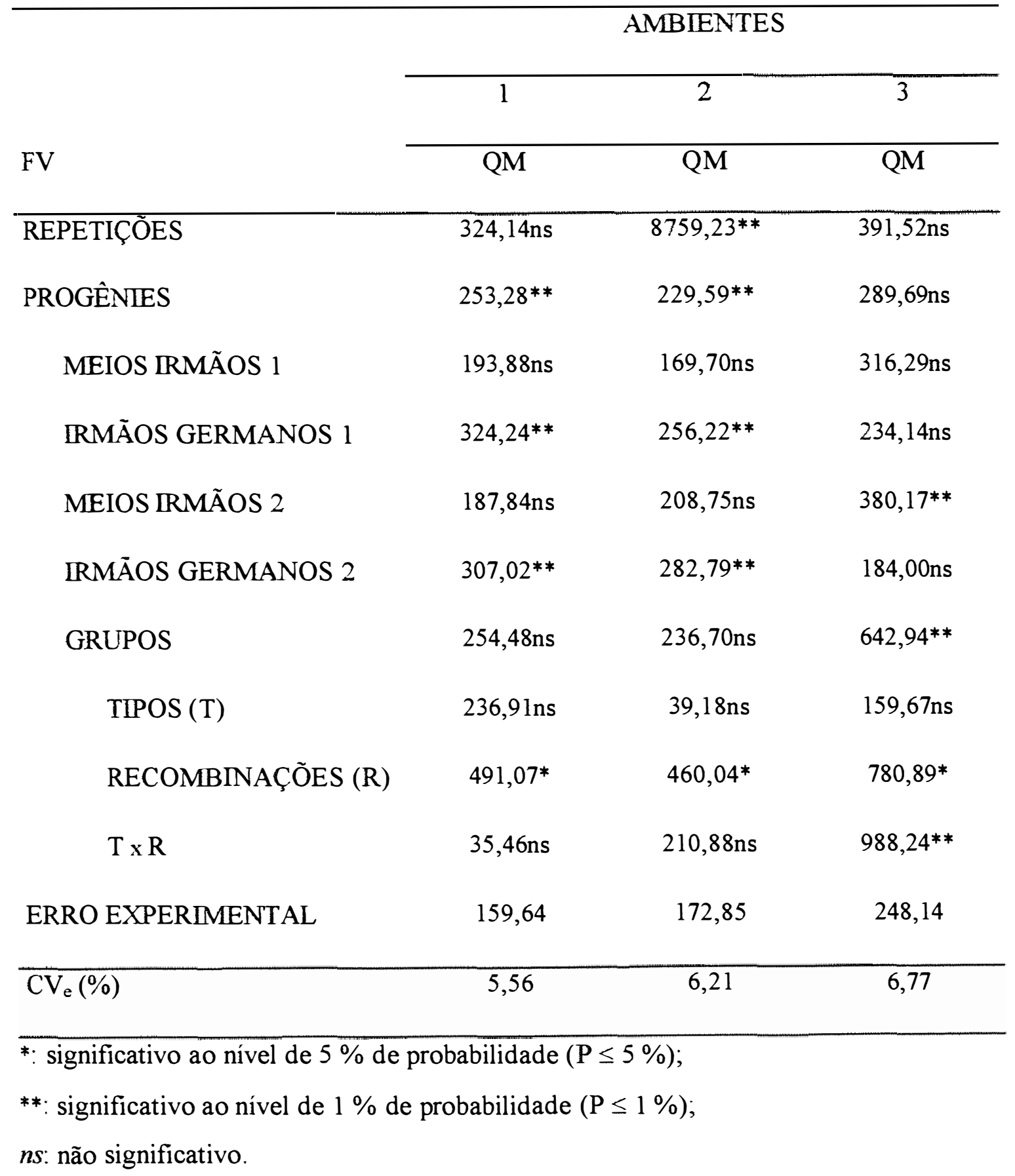


Tabela 12. Análises agrupadas da variância, por ambiente, para o caráter altura da espiga $(\mathrm{AE})$, com as fontes de variação (FV), os quadrados médios (QM), em $(\mathrm{cm} / \text { planta })^{2}$, os testes $\mathrm{F}$ de significância e os coeficientes de variação experimental $\left(\mathrm{CV}_{\mathrm{e}}\right)$, expressos em porcentagem.

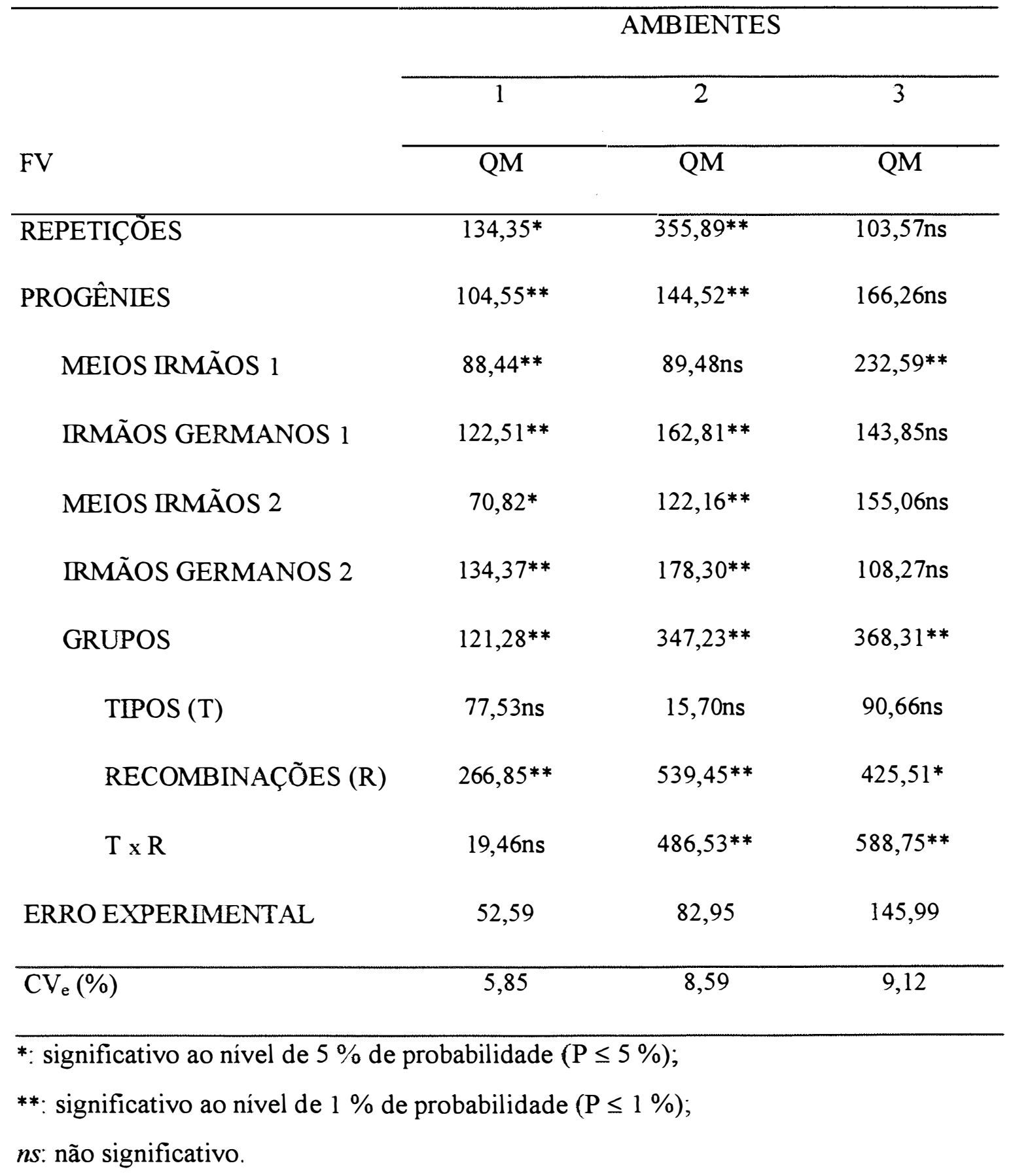


Tabela 13. Análises agrupadas da variância, por ambiente, para o caráter posição relativa da espiga (PR), caráter adimensional, com as fontes de variação (FV), os quadrados médios $\left(\mathrm{QM} \times 10^{-4}\right)$, os testes $\mathrm{F}$ de significância e os coeficientes de variação experimental $\left(\mathrm{CV}_{\mathrm{e}}\right)$, expressos em porcentagem.

\begin{tabular}{|c|c|c|c|}
\hline \multirow[b]{3}{*}{ FV } & \multicolumn{3}{|c|}{ AMBIENTES } \\
\hline & 1 & 2 & 3 \\
\hline & QM & QM & QM \\
\hline REPETIÇŌES & $2,75 \mathrm{~ns}$ & $369,25^{* *}$ & $3,75 \mathrm{~ns}$ \\
\hline PROGÊNIES & $5,64^{* *}$ & $11,05^{* *}$ & $11,65 \mathrm{~ns}$ \\
\hline MEIOS IRMÃOS 1 & $5,85 * *$ & $7,84 \mathrm{~ns}$ & $14,96 *$ \\
\hline IRMÃOS GERMANOS 1 & $5,86^{* *}$ & $10,24^{*}$ & $12,42 \mathrm{~ns}$ \\
\hline MEIOS IRMÃOS 2 & $2,94 \mathrm{~ns}$ & $8,46 \mathrm{~ns}$ & $8,53 \mathrm{~ns}$ \\
\hline IRMÃOS GERMANOS 2 & $7,82^{* *}$ & $13,26^{* *}$ & $9,35 \mathrm{~ns}$ \\
\hline GRUPOS & $6,17 \mathrm{~ns}$ & $46,12^{* *}$ & $22,35^{*}$ \\
\hline TIPOS (T) & $7,23 \mathrm{~ns}$ & $10,16 \mathrm{~ns}$ & $10,34 \mathrm{~ns}$ \\
\hline RECOMBINAÇÕES (R) & $9,82^{*}$ & $51,51^{* *}$ & $37,98^{* *}$ \\
\hline$T \times R$ & $1,48 \mathrm{~ns}$ & $76,69 * *$ & $18,73 \mathrm{~ns}$ \\
\hline ERRO EXPERIMENTAL & 3,71 & 7,50 & 10,65 \\
\hline $\mathrm{CV}_{\mathrm{e}}(\%)$ & 3,53 & 5,47 & 5,74 \\
\hline
\end{tabular}


Tabela 14. Análises agnupadas da variância, por ambiente, para o caráter índice de espigas (IE), caráter adimensional, com as fontes de variação (FV), os quadrados médios ( $\left.\mathrm{QM} \times 10^{-2}\right)$, os testes $\mathrm{F}$ de significância e os coeficientes de variação experimental $\left(\mathrm{CV}_{\mathrm{e}}\right)$, expressos em porcentagem.

\begin{tabular}{|c|c|c|c|}
\hline \multirow[b]{3}{*}{ FV } & \multicolumn{3}{|c|}{ AMBIENTES } \\
\hline & 1 & 2 & 3 \\
\hline & QM & QM & QM \\
\hline REPETIÇÕES & $3,50 \mathrm{~ns}$ & $28,44^{* *}$ & $7,35^{*}$ \\
\hline PROGÊNIES & $2,45 \mathrm{~ns}$ & $5,04 \mathrm{~ns}$ & $4,09 * *$ \\
\hline MEIOS IRMÃOS 1 & $2,00 \mathrm{~ns}$ & $3,03 \mathrm{~ns}$ & $3,20 \mathrm{~ns}$ \\
\hline IRMÃOS GERMANOS 1 & $2,95^{*}$ & $6,96 * *$ & $4,39 * *$ \\
\hline MEIOS IRMÃOS 2 & $2,10 \mathrm{~ns}$ & $5,36 \mathrm{~ns}$ & $3,60^{*}$ \\
\hline IRMÃOS GERMANOS 2 & $2,86 *$ & $4,65 \mathrm{~ns}$ & $4,89 * *$ \\
\hline GRUPOS & $1,73 \mathrm{~ns}$ & $6,18 \mathrm{~ns}$ & $6,42 * *$ \\
\hline TIPOS (T) & $3,29 \mathrm{~ns}$ & $9,39 \mathrm{~ns}$ & $5,87 \mathrm{~ns}$ \\
\hline RECOMBNAÇÕES (R) & $1,00 \mathrm{~ns}$ & $2,53 \mathrm{~ns}$ & $8,64^{*}$ \\
\hline $\mathrm{T} \times \mathrm{R}$ & $0,9 \operatorname{lns}$ & $6,6 \operatorname{lns}$ & $4,74 \mathrm{~ns}$ \\
\hline ERRO EXPERIMENTAL & 2,10 & 4,45 & 2,64 \\
\hline $\mathrm{CV}_{\mathrm{e}}(\%)$ & 13,15 & 20,23 & 15,45 \\
\hline *: significativo ao nível de $5 \%$ de & ilidad & & \\
\hline
\end{tabular}


Tabela 15. Testes Tukey de comparação entre as diversas médias obtidas para o caráter peso de espigas ( $\mathrm{PE}$ ), analisado em ( $\mathrm{g} / \mathrm{planta}$ ), referentes às análises agrupadas, por ambiente.

\begin{tabular}{|c|c|}
\hline CONTRASTES & AMBIENTE 1 \\
\hline MEIOS IRMÃOS $1 \times$ MEIOS IRMÃOS 2 & $2,18 \mathrm{~ns}$ \\
\hline IRMÃOS GERMANOS $1 \times$ IRMÃOS GERMANOS 2 & $5,47 \mathrm{~ns}$ \\
\hline \multirow[t]{2}{*}{ PROGÊNIES DO CICLO $1 \times$ PROGÊNIES DO CICLO 2} & $3,83 \mathrm{~ns}$ \\
\hline & AMBIENTE 2 \\
\hline MEIOS IRMÃOS 1 x MEIOS IRMÃOS 2 & $1,47 \mathrm{~ns}$ \\
\hline IRMÃOS GERMANOS $1 \times$ IRMÃOS GERMANOS 2 & $6,99 \mathrm{~ns}$ \\
\hline \multirow[t]{2}{*}{ PROGÊNIES DO CICLO 1 x PROGÊNIES DO CICLO 2} & $4,23 \mathrm{~ns}$ \\
\hline & AMBIENTE 3 \\
\hline MEIOS IRMÃOS 1 x MEIOS IRMÃOS 2 & $2,36 \mathrm{~ns}$ \\
\hline IRMÃOS GERMANOS 1 x IRMÃOS GERMANOS 2 & $7,79 \mathrm{~ns}$ \\
\hline PROGÊNIES DO CICLO $1 \times$ PROGÊNIES DO CICLO 2 & $5,08 \mathrm{~ns}$ \\
\hline
\end{tabular}

*: significativo ao nível de $5 \%$ de probabilidade $(\mathrm{P} \leq 5 \%)$; ns: não significativo. 
Tabela 16. Testes Tukey de comparação entre as diversas médias obtidas para o caráter altura da planta (AP), analisado em ( $\mathrm{cm} /$ planta), referentes às análises agrupadas, por ambiente.

\begin{tabular}{|c|c|}
\hline CONTRASTES & AMBIENTE 1 \\
\hline MEIOS IRMÃOS $1 \times$ MEIOS IRMÃOS 2 & $2,53 \mathrm{~ns}$ \\
\hline IRMÃOS GERMANOS $1 \times$ IRMÃOS GERMANOS 2 & $2,97 \mathrm{~ns}$ \\
\hline \multirow[t]{2}{*}{ PROGÊNIES DO CICLO $1 \times$ PROGÊNIES DO CICLO 2} & $2,74 \mathrm{~ns}$ \\
\hline & AMBIENTE 2 \\
\hline MEIOS IRMÃOS 1 x MEIOS IRMÃOS 2 & $3,00 \mathrm{~ns}$ \\
\hline IRMÃOS GERMANOS 1 x IRMÃOS GERMANOS 2 & $1,79 \mathrm{~ns}$ \\
\hline \multirow[t]{2}{*}{ PROGÊNIES DO CICLO $1 \times$ PROGÊNIES DO CICLO 2} & $2,39 \mathrm{~ns}$ \\
\hline & AMBIENTE 3 \\
\hline MEIOS IRMÃOS $1 \times$ MEIOS IRMÃOS 2 & $4,67 \mathrm{~ns}$ \\
\hline IRMÃOS GERMANOS $1 \times$ IRMÃOS GERMANOS 2 & $1,89 \mathrm{~ns}$ \\
\hline PROGÊNIES DO CICLO $1 \times$ PROGÊNIES DO CICLO 2 & $1,39 \mathrm{~ns}$ \\
\hline
\end{tabular}

*: significativo ao nível de $5 \%$ de probabilidade (P $\leq 5 \%)$; $n s$ : não significativo. 
Tabela 17. Testes Tukey de comparação entre as diversas médias obtidas para o caráter altura da espiga ( $\mathrm{AE})$, analisado em ( $\mathrm{cm} / \mathrm{planta})$, referentes às análises agrupadas, por ambiente.

\begin{tabular}{|c|c|}
\hline CONTRASTES & AMBIENTE 1 \\
\hline MEIOS IRMÃOS $1 \times$ MEIOS IRMÃOS 2 & $1,79 \mathrm{~ns}$ \\
\hline IRMÃOS GERMANOS $1 \times$ IRMÃOS GERMANOS 2 & $1,79 \mathrm{~ns}$ \\
\hline \multirow[t]{2}{*}{ PROGÊNIES DO CICLO $1 \times$ PROGÊNIES DO CICLO 2} & $1,79 \mathrm{~ns}$ \\
\hline & AMBIENTE 2 \\
\hline MEIOS IRMÃOS $1 \times$ MEIOS IRMÃOS 2 & $4,38 \mathrm{~ns}$ \\
\hline IRMÃOS GERMANOS $1 \times$ IRMÃOS GERMANOS 2 & $1,45 \mathrm{~ns}$ \\
\hline \multirow[t]{2}{*}{ PROGÊNIES DO CICLO 1 x PROGÊNIES DO CICLO 2} & $2,92 \mathrm{~ns}$ \\
\hline & AMBIENTE 3 \\
\hline MEIOS IRMÃOS $1 \times$ MEIOS IRMÃOS 2 & $1,31 \mathrm{~ns}$ \\
\hline IRMÃOS GERMANOS $1 \times$ IRMÃOS GERMANOS 2 & $3,21 \mathrm{~ns}$ \\
\hline PROGÊNIES DO CICLO $1 \times$ PROGÊNIES DO CICLO 2 & $0,95 \mathrm{~ns}$ \\
\hline
\end{tabular}

*: significativo ao nível de $5 \%$ de probabilidade $(\mathrm{P} \leq 5 \%)$; $n s$ : não significativo. 
Tabela 18. Testes Tukey de comparação entre as diversas médias obtidas para o caráter posição relativa da espiga ( $\mathrm{PR})$, caráter adimensional, referentes às análises agrupadas, por ambiente. Os contrastes estão multiplicados por $10^{4}$.

\begin{tabular}{|c|c|}
\hline CONTRASTES & AMBIENTE 1 \\
\hline MEIOS IRMÃOS $1 \times$ MEIOS IRMÃOS 2 & $20,00 \mathrm{~ns}$ \\
\hline IRMÃOS GERMANOS 1 x IRMÃOS GERMANOS 2 & $2,50 \mathrm{~ns}$ \\
\hline \multirow[t]{2}{*}{ PROGÊNIES DO CICLO $1 \times$ PROGÊNIES DO CICLO 2} & $11,25 \mathrm{~ns}$ \\
\hline & AMBIENTE 2 \\
\hline MEIOS IRMÃOS $1 \times$ MEIOS IRMÃOS 2 & $150,00^{*}$ \\
\hline IRMÃOS GERMANOS 1 x RMÃOS GERMANOS 2 & $27,50 \mathrm{~ns}$ \\
\hline \multirow[t]{2}{*}{ PROGÊNIES DO CICLO 1 x PROGÊNIES DO CICLO 2} & $88,75 \mathrm{~ns}$ \\
\hline & AMBIENTE 3 \\
\hline MEIOS IRMÃOS 1 x MEIOS IRMÃOS 2 & $40,00 \mathrm{~ns}$ \\
\hline IRMÃOS GERMANOS 1 x IRMÃOS GERMANOS 2 & $77,50 \mathrm{~ns}$ \\
\hline PROGÊNIES DO CICLO $1 \times$ PROGÊNIES DO CICLO 2 & $58,75 \mathrm{~ns}$ \\
\hline
\end{tabular}


Tabela 19. Testes Tukey de comparação entre as diversas médias obtidas para o caráter índice de espigas (IE), caráter adimensional, referentes às análises agrupadas, por ambiente. Os contrastes estão multiplicados por $10^{2}$.

\begin{tabular}{|c|c|}
\hline CONTRASTES & AMBIENTE 1 \\
\hline MEIOS IRMÃOS 1 x MEIOS IRMÃOS 2 & $1,25 \mathrm{~ns}$ \\
\hline IRMÃOS GERMANOS 1 x IRMÃOS GERMANOS 2 & $0,00 \mathrm{~ns}$ \\
\hline \multirow[t]{2}{*}{ PROGÊNIES DO CICLO $1 \times$ PROGÊNIES DO CICLO 2} & $0,63 \mathrm{~ns}$ \\
\hline & AMBIENTE 2 \\
\hline MEIOS IRMÃOS 1 x MEIOS IRMÃOS 2 & $1,40 \mathrm{~ns}$ \\
\hline IRMÃOS GERMANOS 1 x IRMÃOS GERMANOS 2 & $3,23 \mathrm{~ns}$ \\
\hline \multirow[t]{2}{*}{ PROGÊNIES DO CICLO $1 \times$ PROGÊNIES DO CICLO 2} & $0,91 \mathrm{~ns}$ \\
\hline & AMBIENTE 3 \\
\hline MEIOS IRMÃOS $1 \times$ MEIOS IRMÃOS 2 & $2,20 \mathrm{~ns}$ \\
\hline IRMÃOS GERMANOS $1 \times$ IRMÃOS GERMANOS 2 & $1,15 \mathrm{~ns}$ \\
\hline PROGÊNIES DO CICLO $1 \times$ PROGÊNIES DO CICLO 2 & $0,52 \mathrm{~ns}$ \\
\hline
\end{tabular}

*: significativo ao nível de $5 \%$ de probabilidade (P $\leq 5 \%$ ); $n s$ : não significativo. 


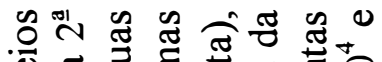

'す

व

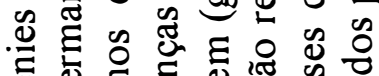

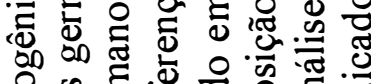

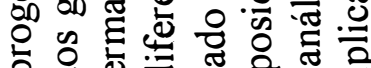

ᄋํำ

胥

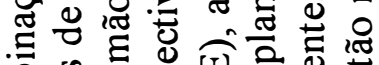

है.

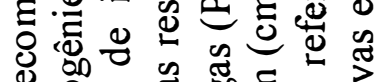

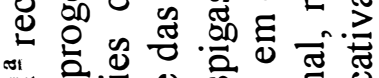

- 2. 0 के

ชิ

\% 胥

更:

जह है की है की

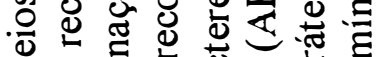

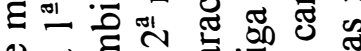

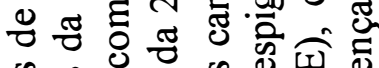

\& \& d \& 0 \&

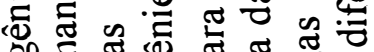

రำ

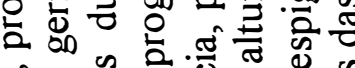

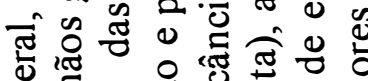

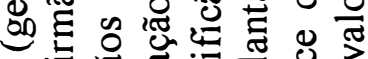

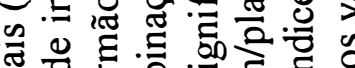

क्षे

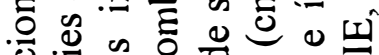

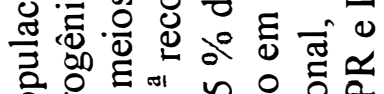

¿

: జ

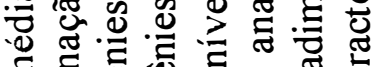

E.

क है 00

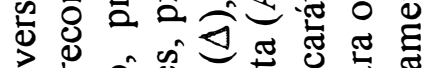

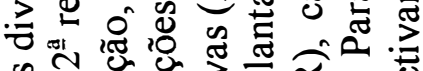

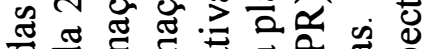

क क

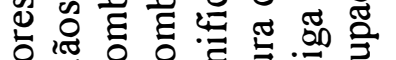

施

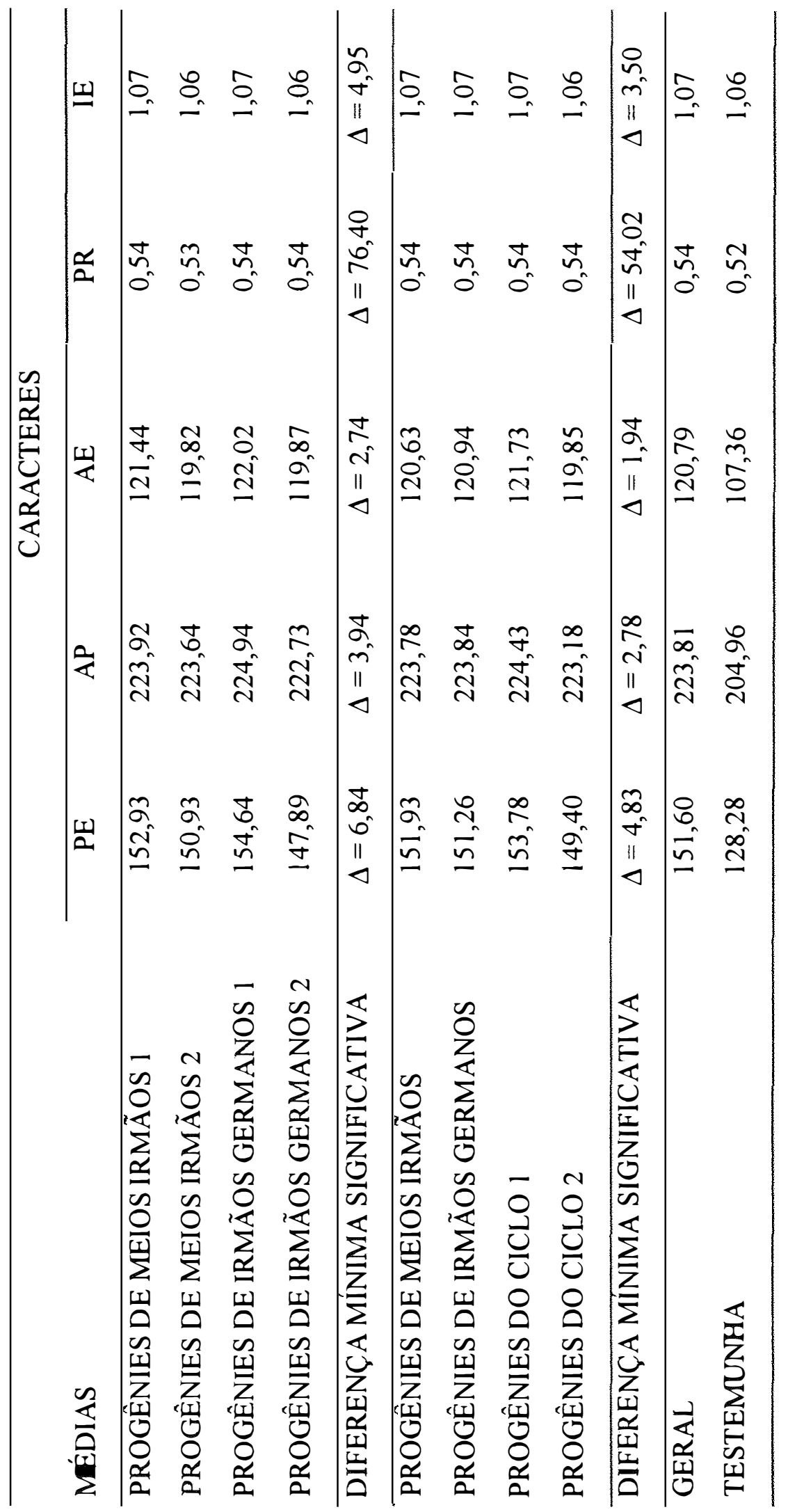




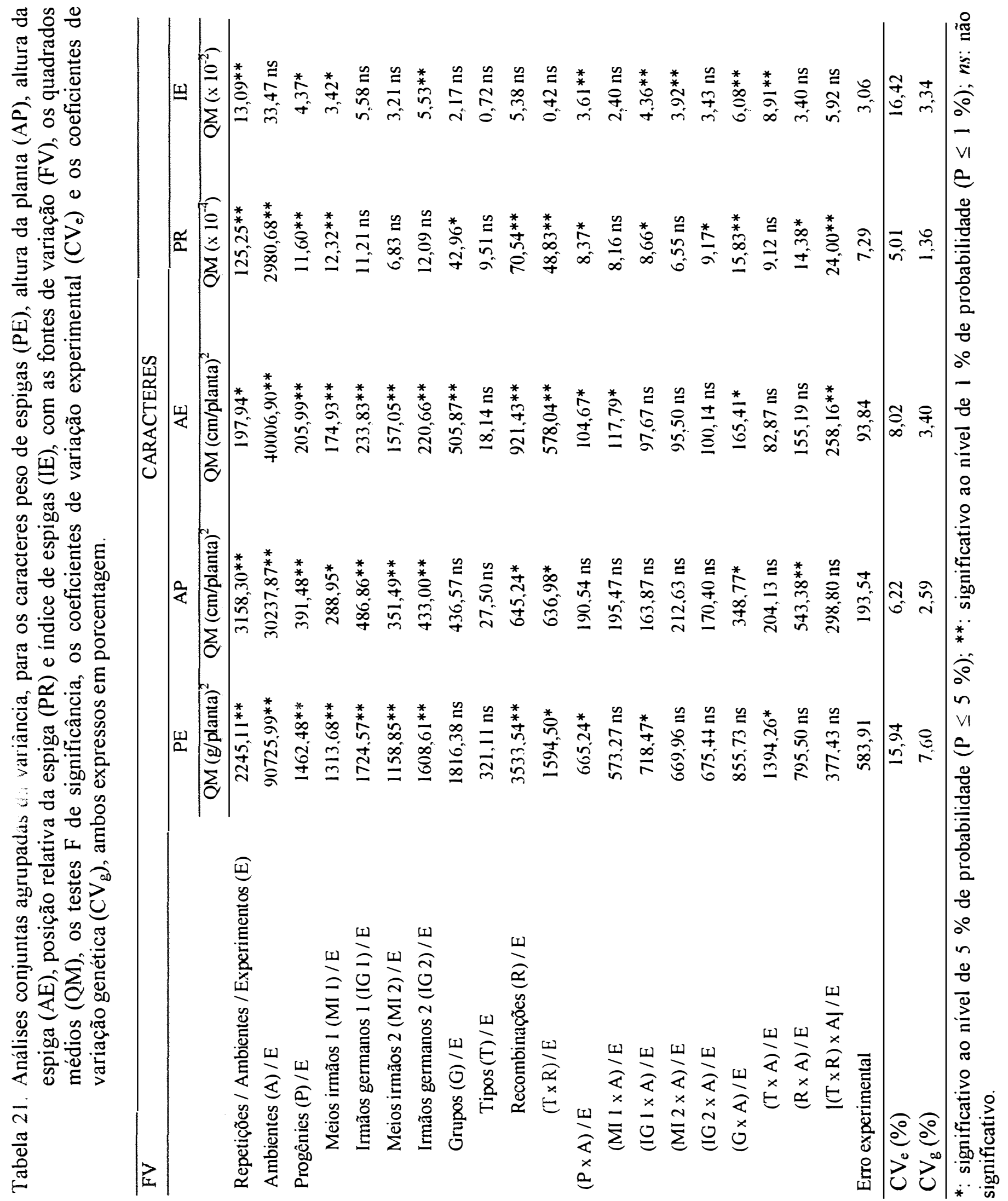


Tabela 22. Testes Tukey de comparação entre as diversas médias observadas para os caracteres peso de espigas (PE), analisado em (g/planta), altura da planta (AP), analisado em (cm/planta), altura da espiga (AE), analisado em ( $\mathrm{cm} /$ planta), posição relativa da espiga (PR), caráter adimensional, e índice de espigas (IE), caráter adimensional, referentes às análises conjuntas agrupadas. Para os caracteres PR e IE, os contrastes estão multiplicados por $10^{4}$ e por $10^{2}$, respectivamente.

CONTRASTES

CARACTERES

\section{PE}

MEIOS IRMÃOS 1 x MEIOS IRMÃOS 2

$2,00 \mathrm{~ns}$

IRMÃOS GERMANOS $1 \times$ IRMÃOS GERMANOS 2

$6,75 \mathrm{~ns}$

PROGÊNIES DO CICLO $1 \times$ PROGÊNIES DO CICLO 2

$4,38 \mathrm{~ns}$

MEIOS IRMÃOS $1 \times$ MEIOS IRMÃOS 2

AP

IRMÃOS GERMANOS 1 x IRMÃOS GERMANOS 2

$0,28 \mathrm{~ns}$

$2,21 \mathrm{~ns}$

PROGÊNIES DO CICLO $1 \times$ PROGÊNIES DO CICLO 2

$1,25 \mathrm{~ns}$

\begin{tabular}{c}
\hline $\mathrm{AE}$ \\
\hline $1,62 \mathrm{~ns}$ \\
$2,15 \mathrm{~ns}$ \\
$1,88 \mathrm{~ns}$ \\
\hline $\mathrm{PR}$
\end{tabular}

MEIOS IRMÃOS 1 x MEIOS IRMÃOS 2

$70,00 \mathrm{~ns}$

IRMÃOS GERMANOS $1 \times$ IRMÃOS GERMANOS 2

$35,83 \mathrm{~ns}$

PROGÊNIES DO CICLO $1 \times$ PROGÊNIES DO CICLO 2

$52,92 \mathrm{~ns}$

\begin{tabular}{c}
$70,00 \mathrm{~ns}$ \\
$35,83 \mathrm{~ns}$ \\
$52,92 \mathrm{~ns}$ \\
\hline $\mathrm{IE}$ \\
\hline $0,69 \mathrm{~ns}$ \\
$0,69 \mathrm{~ns}$ \\
$0,69 \mathrm{~ns}$
\end{tabular}

MEIOS IRMÃOS $1 \times$ MEIOS IRMÃOS 2

IRMÃOS GERMANOS 1 x IRMÃOS GERMANOS 2

PROGÊNIES DO CICLO 1 x PROGÊNIES DO CICLO 2

*: significativo ao nível de $5 \%$ de probabilidade ( $\leq 5 \%)$; ns: não significativo. 


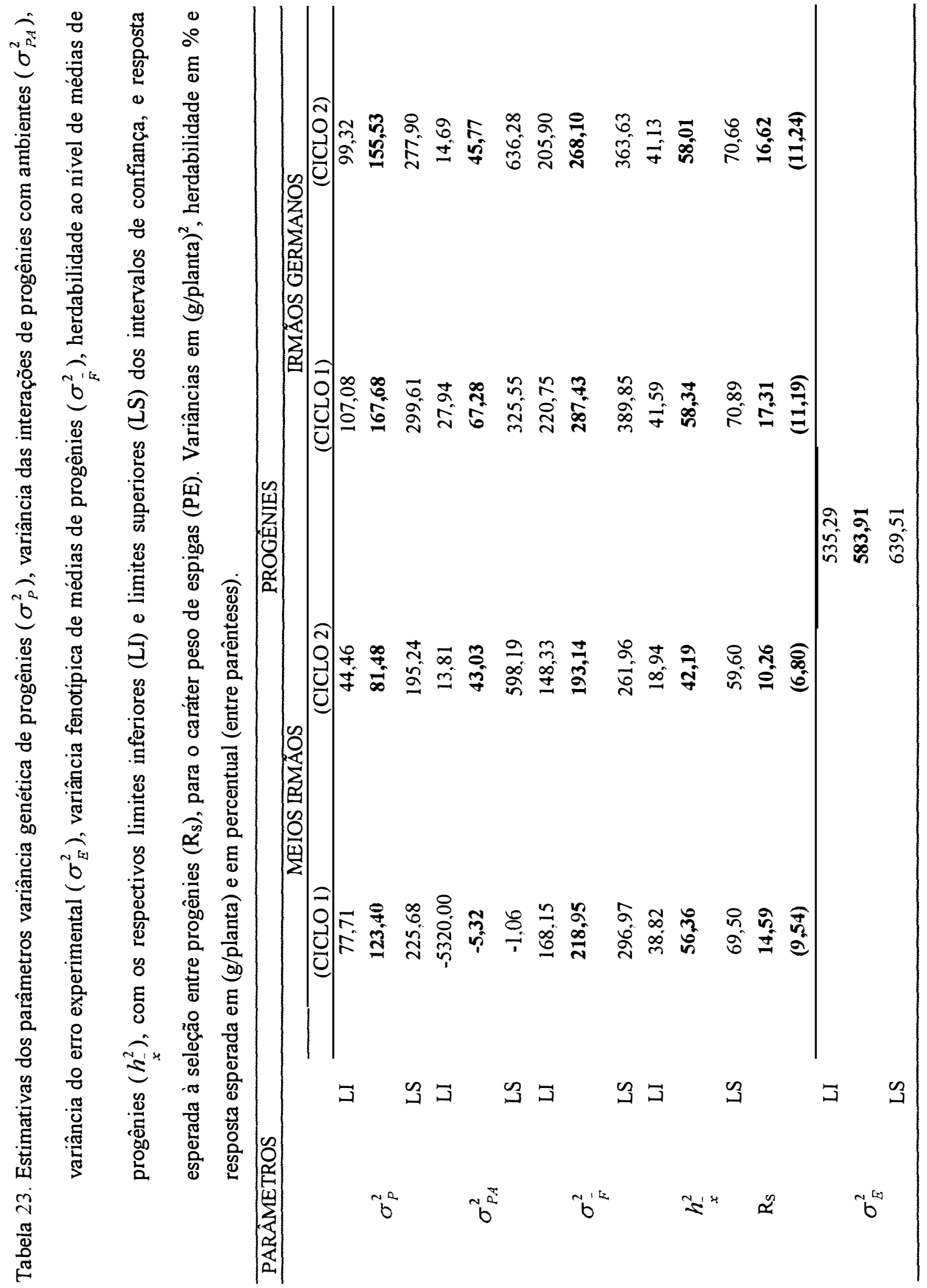




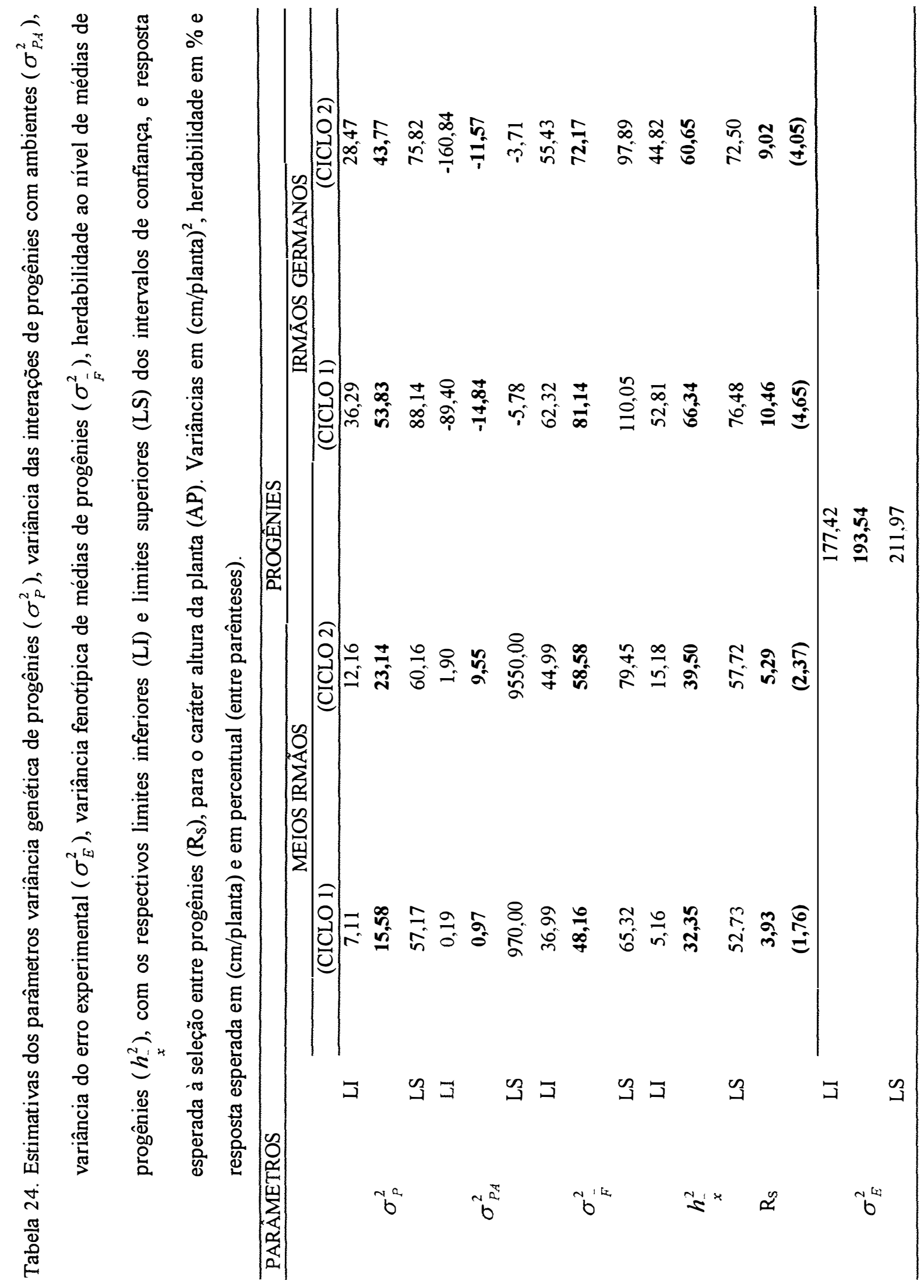




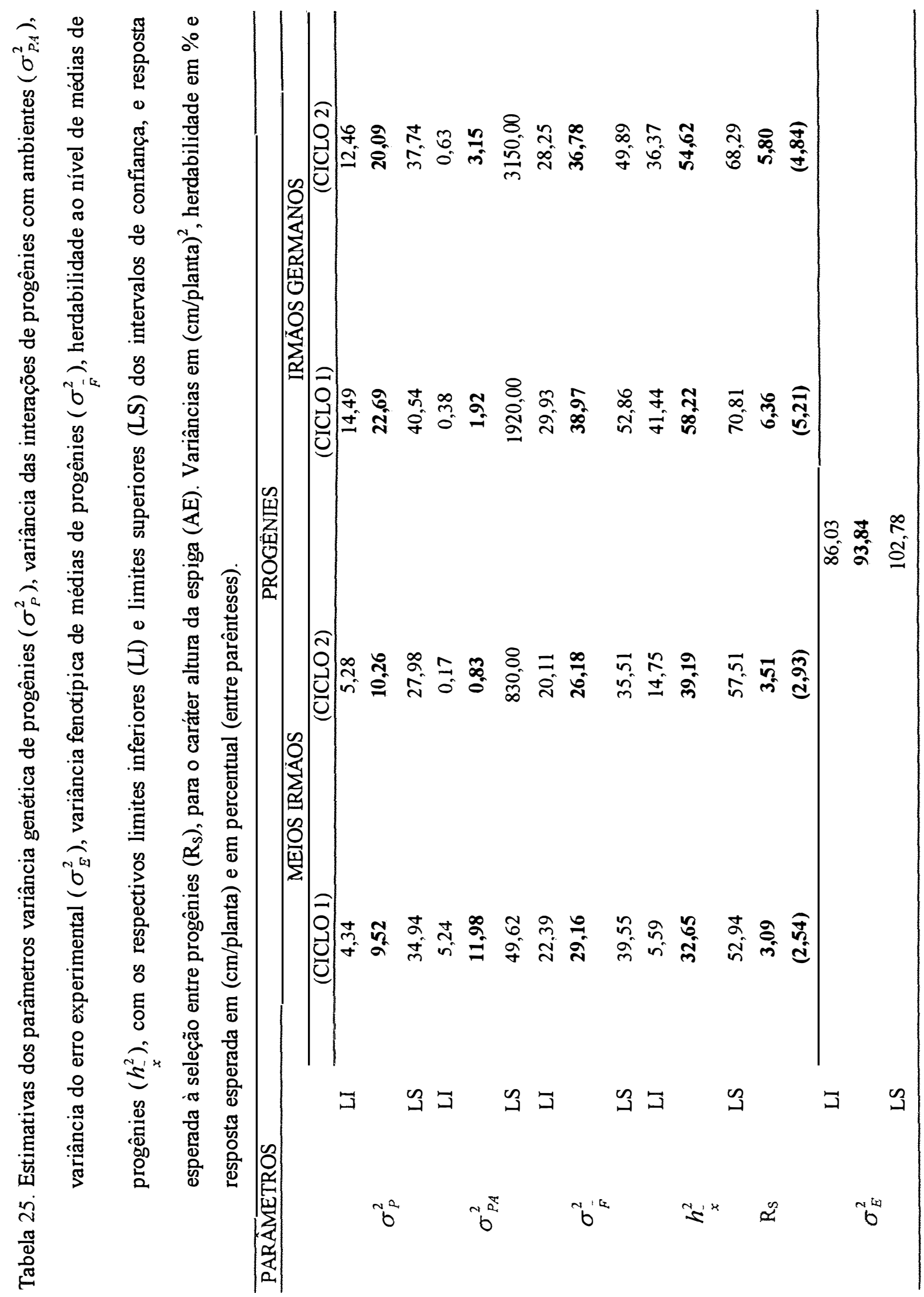




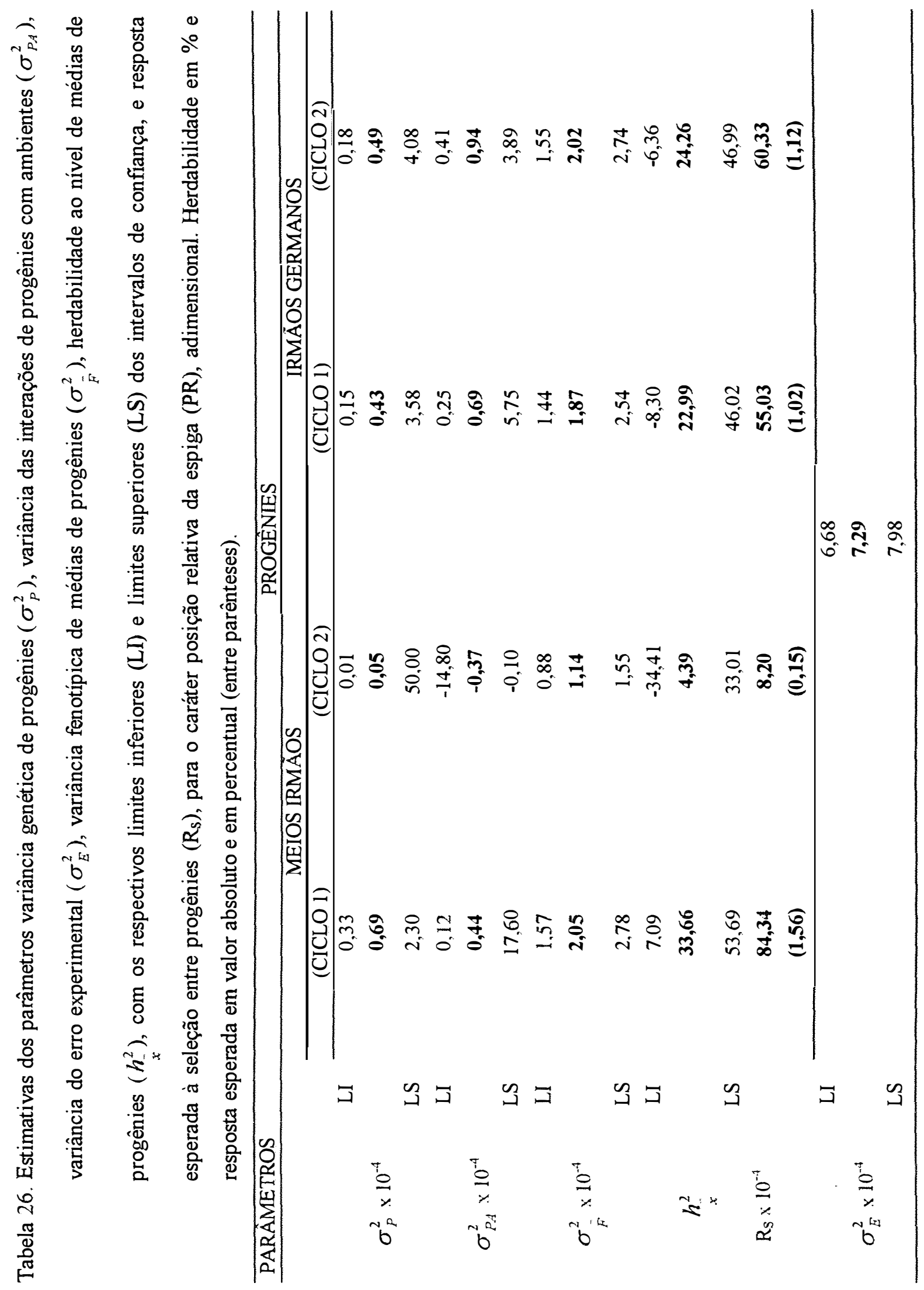




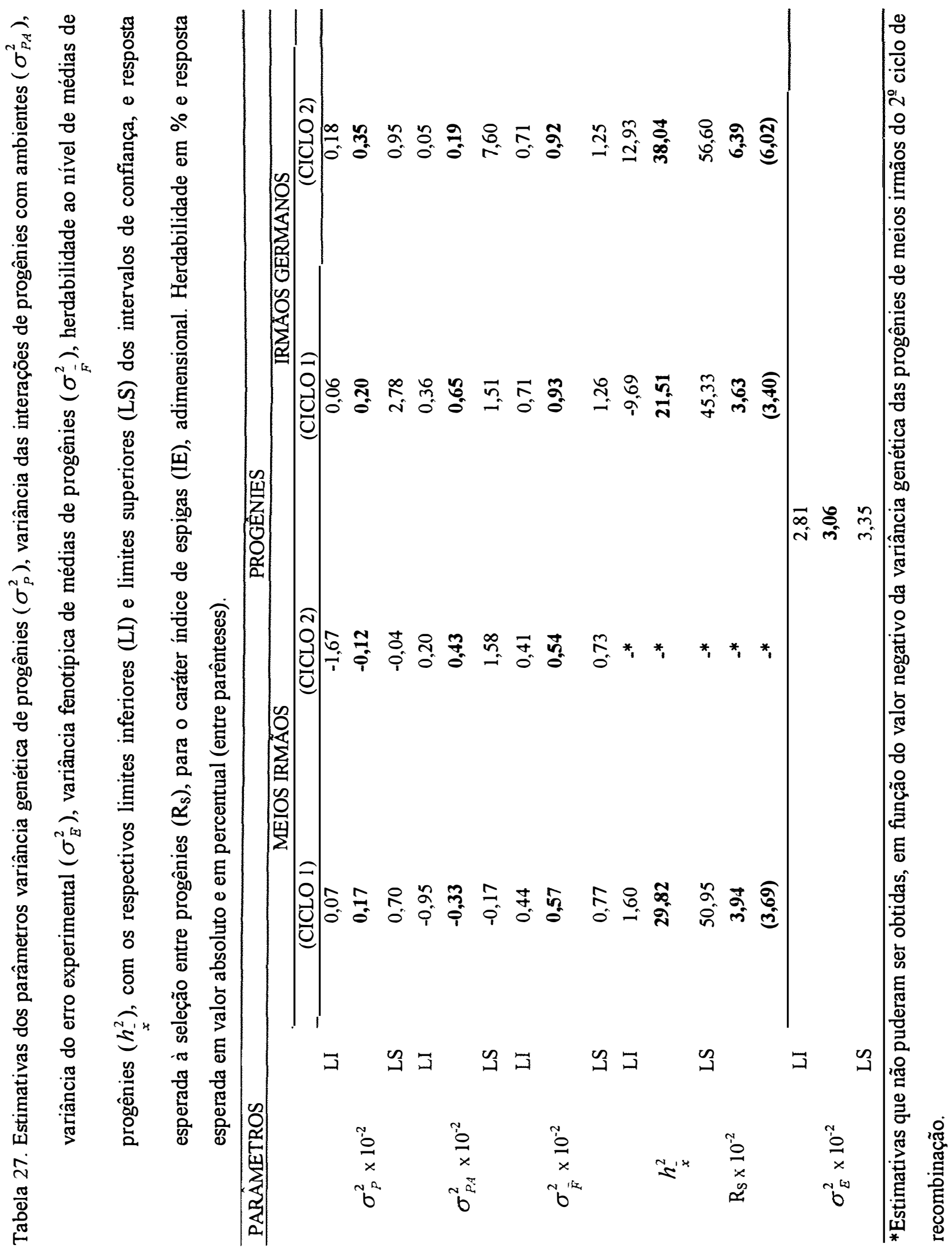




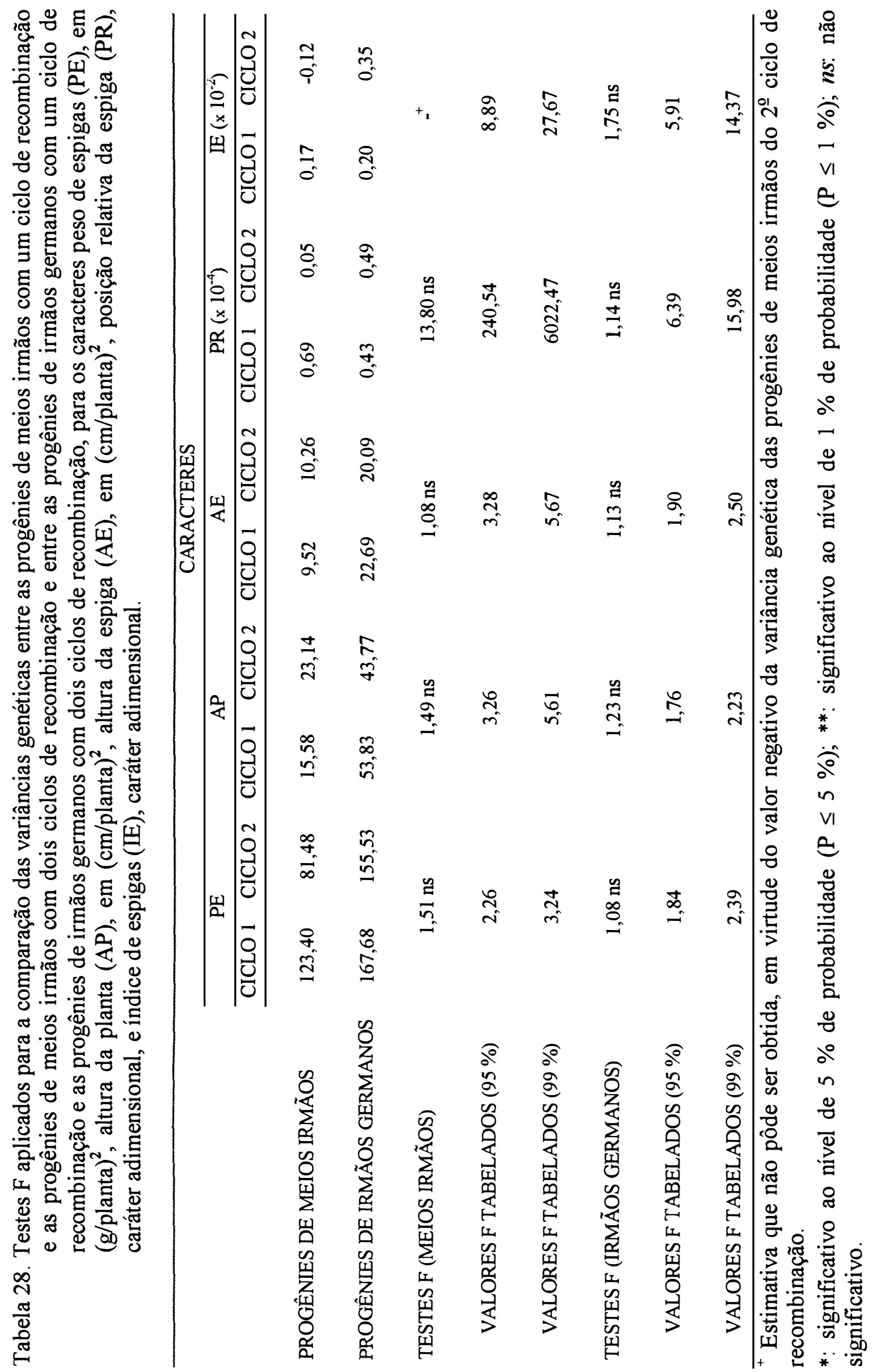


善

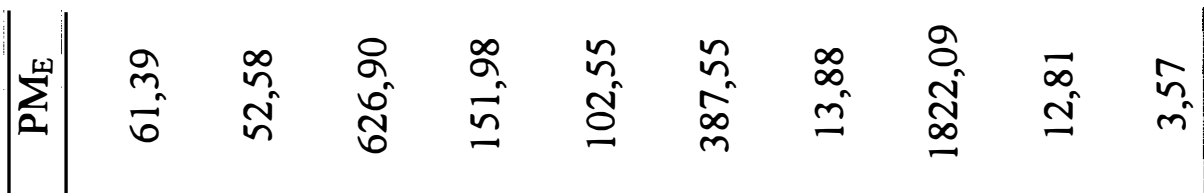

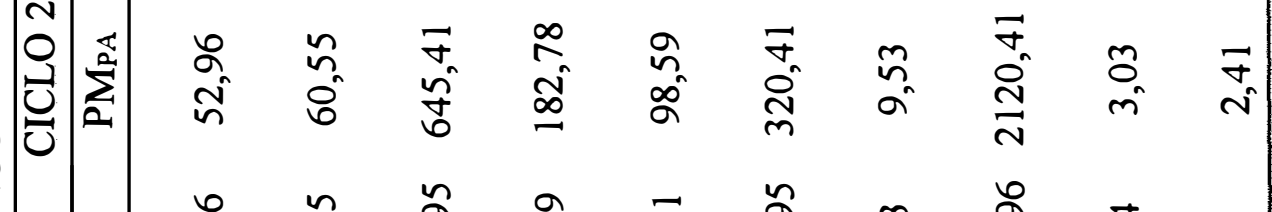

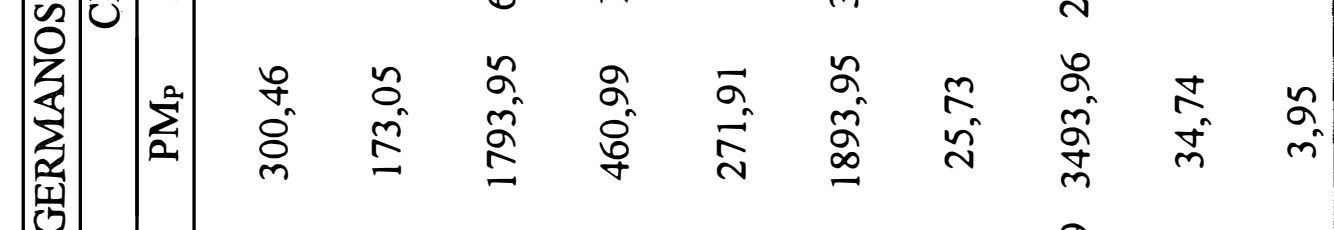

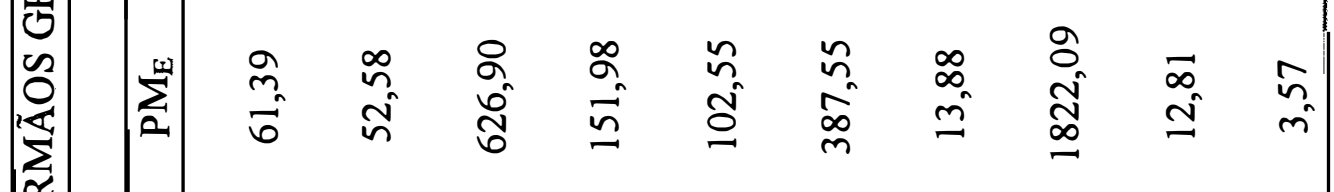

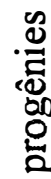

局

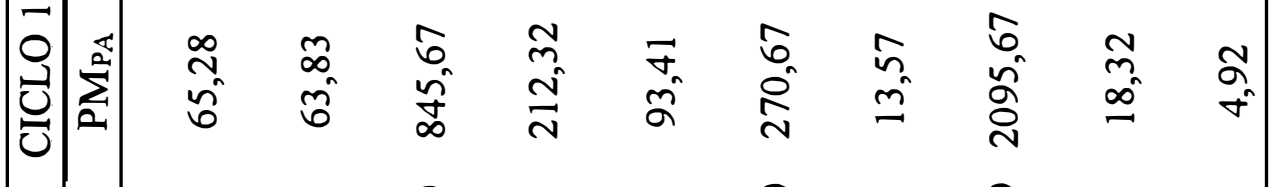

ชี

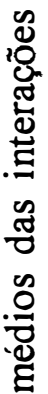

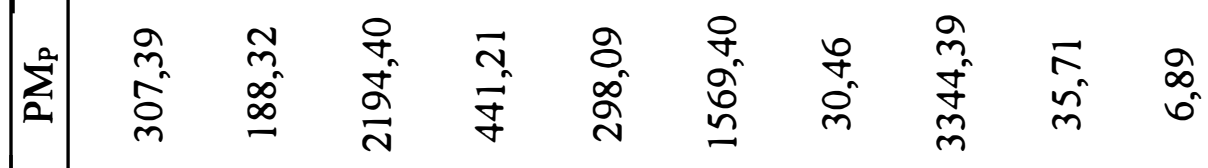

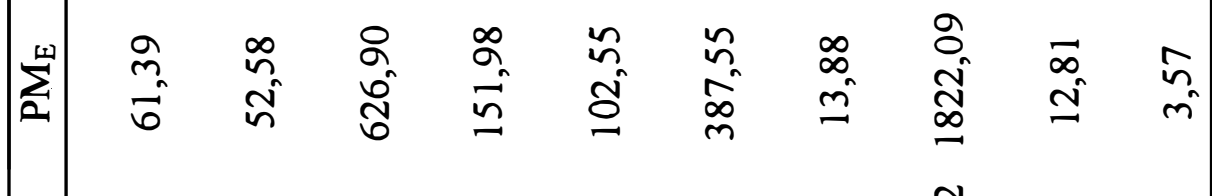

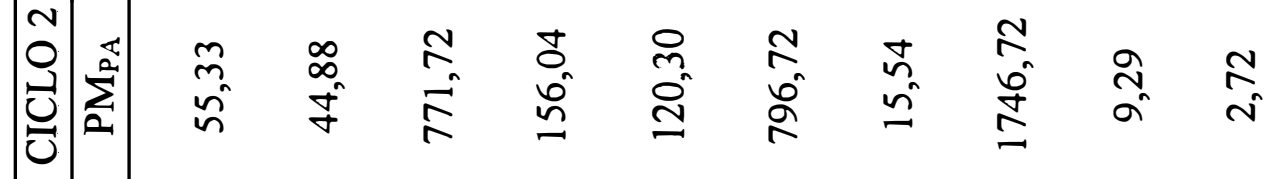

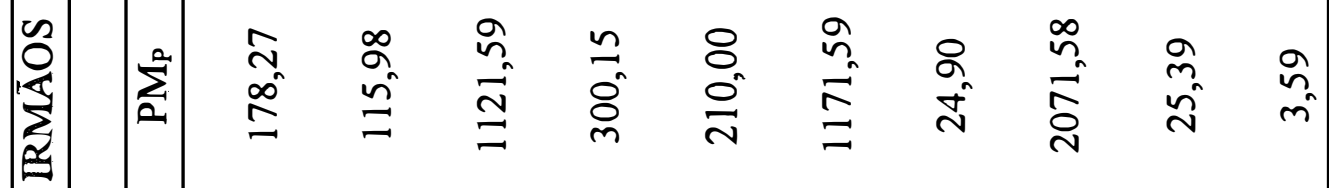

م્

(în

\&

谣

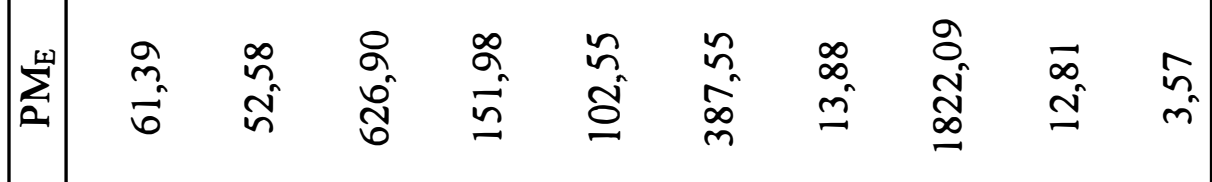

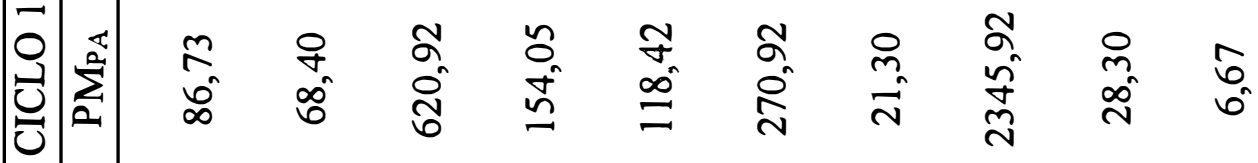

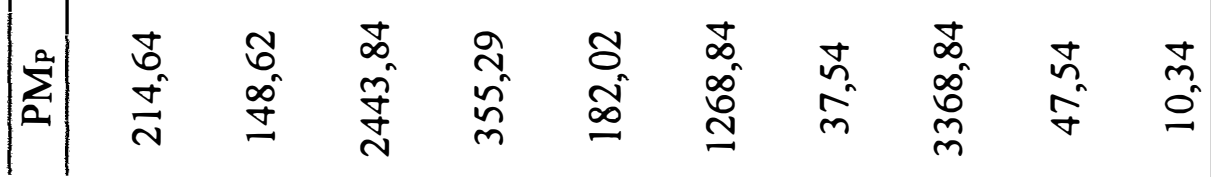

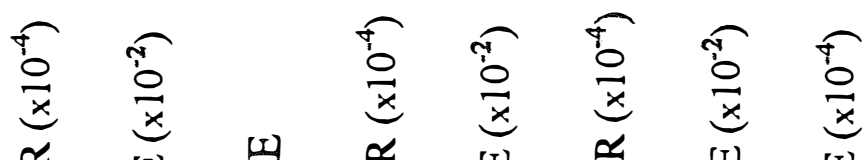

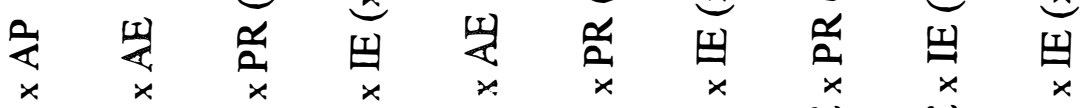

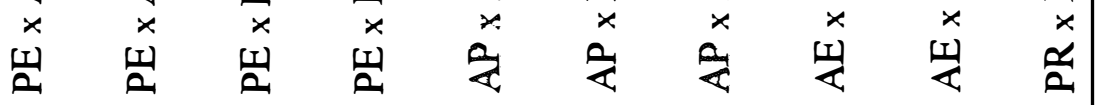




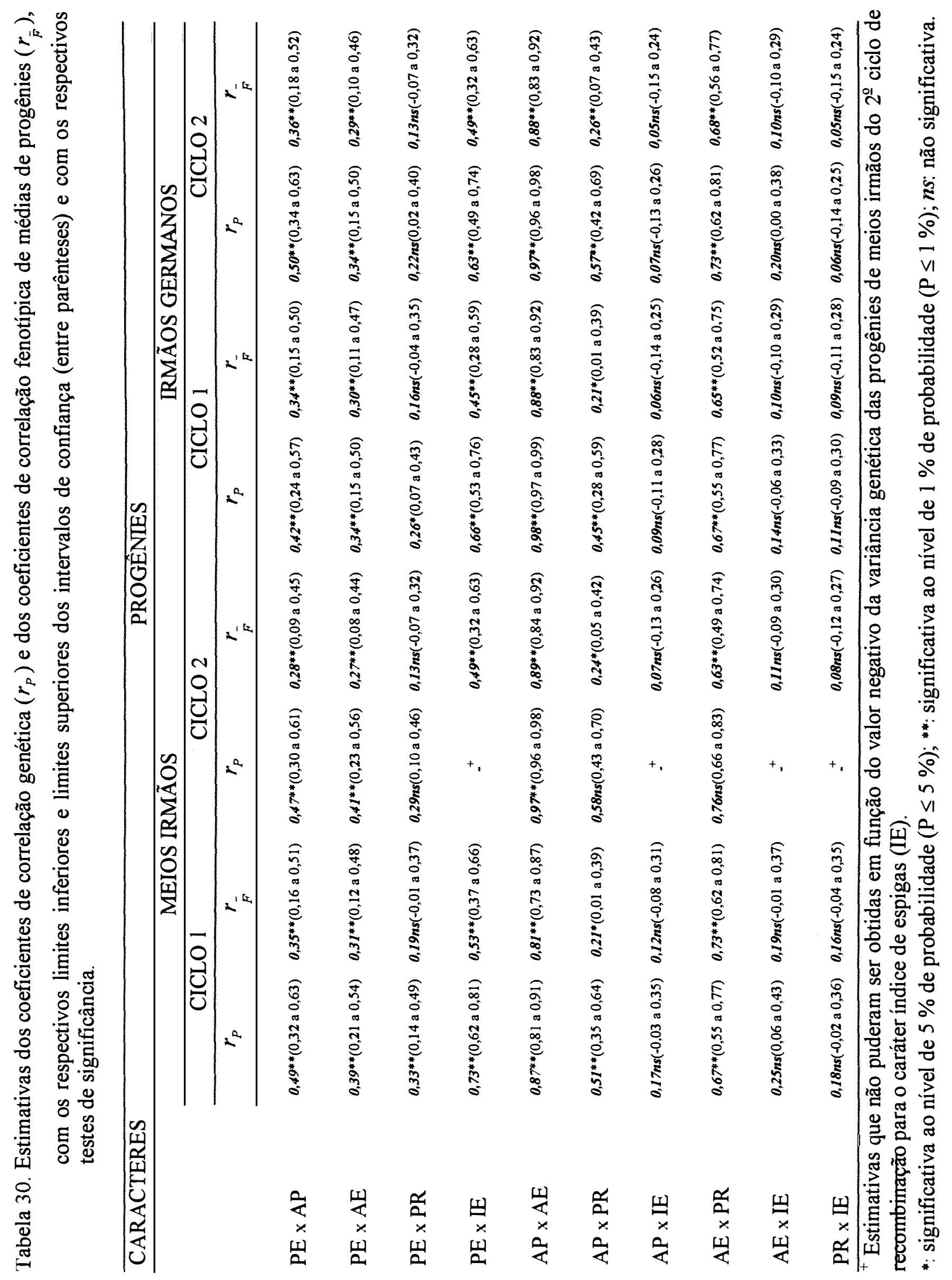

